Leandro Cardoso Marques da Silva

\title{
A consciência intencional no jovem Sartre: bases fenomenológicas e perspectivas éticas
}

Dissertação de mestrado

Versão Corrigida

Orientador: Professor Doutor Marcus Sacrini Ayres Ferraz

Universidade de São Paulo

Faculdade de Filosofia Letras e Ciências Humanas

São Paulo - SP 



\section{A consciência intencional no jovem Sartre: bases fenomenológicas e perspectivas éticas}

Versão Corrigida

DISSERTAÇÃO APRESENTADA À BANCA EXAMINADORA DO PROGRAMA DE PÓSGRADUAÇÃO EM FILOSOFIA, DA FACULDADE DE FILOSOFIA LETRAS E CIÊNCIAS HUMANAS DA UNIVERSIDADE DE SÃO PAULO, COMO EXIGÊNCIA PARCIAL PARA A OBTENÇÃO DO TÍTULO DE MESTRE EM FILOSOFIA NA ÁREA DE FILOSOFIA CONTEMPORÂNEA, SOB A ORIENTAÇÃO DO PROFESSOR MARCUS SACRINI.

São Paulo 
Autorizo a reprodução e divulgação total ou parcial deste trabalho, por qualquer meio convencional ou eletrônico, para fins de estudo e pesquisa, desde que citada a fonte.

Catalogação na Publicação

Serviço de Biblioteca e Documentação

Faculdade de Filosofia, Letras e Ciências Humanas da Universidade de São Paulo

d586c

da Silva, Leandro Cardoso Marques da Silva

A consciência intencional no jovem Sartre: bases fenomenológicas, perspectivas éticas / Leandro Cardoso Marques da Silva da Silva; orientador Marcus Sacrini Ayres Ferraz Sacrini. - São Paulo, 2019 .

$134 \mathrm{f}$.

Dissertação (Mestrado)- Faculdade de Filosofia, Letras e Ciências Humanas da Universidade de São Paulo. Departamento de Filosofia. Área de concentração: Filosofia.

1. Filosofia . 2. Filosofia Contemporânea Francesa. 3. Fenomenologia. 4. Epistemologia. 5. Ética. I. Sacrini, Marcus Sacrini Ayres Ferraz, orient. II. Título. 


\section{ENTREGA DO EXEMPLAR CORRIGIDO DA DISSERTACÃ̃O/TESE}

\section{Termo de Ciência e Concordância do (a) orientador (a)}

Nome do (a) aluno (a): LEANDRO CARDOSO MRQUES DA SILUA

Data da defesa: $12,08,2019$

Nome do Prof. (a) orientador (a): Mancus Sacrin;

Nos termos da legislação vigente, declaro ESTAR CIENTE do conteúdo deste EXEMPLAR CORRIGIDO elaborado em atenção às sugestōes dos membros da comissão Julgadora na sessão de defesa do trabalho, manifestando-me plenamente favorável ao seu encaminhamento e publicação no Portal Digital de Teses da USP.

São Paulo,

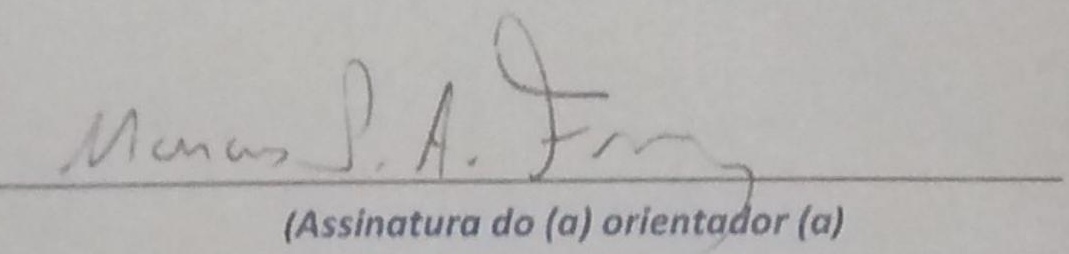



À minha mãe, Maria Emilia Cardoso Pinto 


\section{Agradecimentos}

Agradeço às entidades que permitiram a realização desta pesquisa, ao CNPq que a financiou e ao departamento de Filosofia da USP. Neste sentido, deve constar minha gratidão, principalmente, aos funcionários da secretaria do departamento cujos nomes merecem menção Geni Lima e Luciana Nóbrega, que sempre me atenderam com paciência e gentileza. Também sou cordialmente grato aos professores da mesa de defesa e de qualificação Alexandre Carrasco e Alex Moura, que gentilmente leram minha pesquisa e trouxeram comentários enriquecedores.

Este trabalho é resultado de muitos anos de pesquisa, iniciados na já distante iniciação científica. Eu gostaria de expressar minha gratidão por todos aqueles que passaram por meu caminho ao longo desses anos de estudo que remontam ao início da graduação. Minha formação, como pesquisador e como pessoa, se deve à presença de várias pessoas que compartilharam comigo desses anos e dessa árdua trilha que é a formação em humanidades. Desde meus colegas calouros da saudosa geração de 2007, até aqueles que compartilharam de experiências no movimento estudantil, são muitas as pessoas que eu gostaria de citar, mas que, infelizmente, a memória e o espaço não me permitem mencionar um a um. Ainda assim, há aqueles nomes especiais que não poderiam deixar de constar: Os colegas de CAF e república; Orlando Lima Pimentel e João Pedro Bueno, nossas aventuras não podem ser esquecidas. Os colegas de anos de FFLCH; Douglas Romão, Ricardo Streich, Glauce Fi, João Victor Kosicki Serpa e Diego Ramos, encontros felizes, pessoas cujas presenças melhoraram e ainda melhoram significativamente os corredores desta faculdade. Os colegas filósofos cuja amizade transcende a faculdade: Jonas Mur, maiêutico, destemido professor; Homero Souza Filho, cuja amizade é uma honra, conhecido pela alcunha de Pelego e pai de Daruê; Pedro Gabriel Amaral Costa, queridíssimo primeiro e maior amigo da faculdade, pessoa que melhora todos os lugares. Na lista de "filósofos" também caberia Fernando Rondelli (Peter) dos Reis, mas nossa amizade de mais de uma década e o companheirismo de aventuras extra-acadêmicas o destacam dessa lista, excepcional músico e amigo de cuja companhia ainda quero gozar por longos anos.

Além dos colegas de faculdade, muitas outras pessoas têm me apoiado nesta trajetória. Quero destacar meu grande amigo Edson Bini, meu veterano na Filosofia, no 
ofício de tradução e na vida, que tantas vezes me ajudou com apoio material e moral. Também é digna de menção a iniciativa do PLEA na qual sou monitor e que tem enriquecido minha carreira acadêmica, dentre os muitos colegas, deve constar o nome de Guilherme Diniz. Expresso minha gratidão pelas funcionárias das bibliotecas de ECA e da FFLCH com quem eu tive o prazer de trabalhar, em especial à Rita Joly e Maria das Graças dos Santos. Para além da faculdade, a lista de agradecimentos seria muito extensa, tantos familiares como amigos, muitos deveriam constar aqui. Dessa lista, preciso mencionar o nome de Tales Giannico Alberto Cordeiro, cuja amizade de mais de duas décadas têm contribuído para minha pessoa numa escala que não posso mensurar, a quem, inclusive, devo a ideia de ter prestado o vestibular que me colocou nesta faculdade. Também não posso deixar de citar o Doutor Alexandre Okanobo, preclaro discípulo de Hipócrates, que por pura humanidade e com muita competência tem tratado de minha saúde psíquica, condição sine qua non da realização deste trabalho. Agradeço à Marina Bagatini, uma pessoa maravilhosa que contribuiu com uma tradução para esta dissertação. Dessa lista, ainda quero mencionar a pessoa que apareceu por último em minha vida - e espero que nela permaneça, a promissora acadêmica Camila Helena Pivante, cuja presença afetuosa constituiu a energia e o ânimo destes últimos tempos de vida e trabalho, a quem devo, inclusive, o apoio emocional e executivo nestas últimas horas de compromisso com a dissertação.

Por fim, quero destacar o agradecimento especial para estas pessoas a quem, aliás, dedico este trabalho: minha grande amiga Mariana Ribeiro dos Santos, sem o seu apoio moral (e muitas vezes material) esta pesquisa talvez jamais tivesse se iniciado. Agradeço ao professor Marcus Sacrini por todos estes sete longos anos de orientação. Este excepcional professor orientou esta pesquisa com muita atenção e competência, e, em mais de uma ocasião, prestou-me auxílios que extrapolavam a esfera de obrigações de um orientador. Se hoje sei escrever um texto acadêmico, devo agradecer ao professor Sacrini. Final e especialmente, agradeço a minha amada mãe Maria Emilia. Se cheguei onde estou hoje, devo tudo a ela que corajosa e carinhosamente me criou sozinha entre tantas adversidades. A ela dedico minhas conquistas. 
Título: A consciência intencional no jovem Sartre: bases fenomenológicas e perspectivas éticas

Resumo: Esta pesquisa visa a estudar a concepção de consciência intencional nas obras do jovem Sartre. Nos anos 30, o filósofo francês desenvolve uma concepção fenomenológica da consciência com a qual critica a psicologia de sua época. Pode-se dizer que toda a tensão conceitual da produção deste período está em torno da noção de consciência a ser disputada tanto com a fenomenologia de Husserl, quanto com a psicologia. Sartre elabora sua concepção a partir do conceito de intencionalidade, segundo o qual a consciência se constitui num movimento de exteriorização ao mundo. O resultado disso é uma filosofia que imerge, ontologicamente, o sujeito no mundo negando o solipsismo. Ao mesmo tempo é uma filosofia da liberdade, pois afirma a espontaneidade da consciência que não pode ser mecanizada por nenhuma teoria psicológica de viés materialista.

Palavras chave: Sartre, fenomenologia, consciência, intencionalidade, ética.

Title: The intentional consciousness on young Sartre: phenomenological groundwork and ethical perspectives.

Abstract: This research envisages studying the conception of intentional consciousness on the work of young Sartre. In the 30s, the French philosopher develops a phenomenological concept of consciousness with which he criticizes the psychology of his time. You could say all the conceptual tension of the production during that period is around the notion of consciousness to be disputed by Husserl's phenomenology and by psychology. Sartre elaborates his conception from the concept of intentionality, according to which the consciousness is built in a moment of externalization from the world. Its result is a philosophy that immerges, ontologically, with the subject in the world denying solipsism. At the same time that it is a philosophy of freedom, since it states the spontaneity of consciousness that cannot be mechanized by any psychological theory with a materialist bias.

Key-words: Sartre, phenomenology, consciousness, intentionality, ethics. 



\section{Sumário:}

Introdução

1. Purificação da consciência transcendental: combate ao idealismo......................19

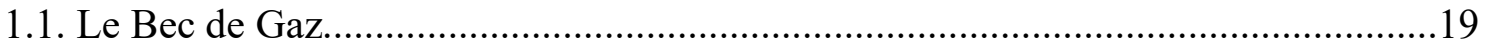

1.2. A intencionalidade: entre a herança fenomenológica e o apelo realista....................25

1.2.1. Breve histórico do conceito: da filosofia escolástica à fenomenologia

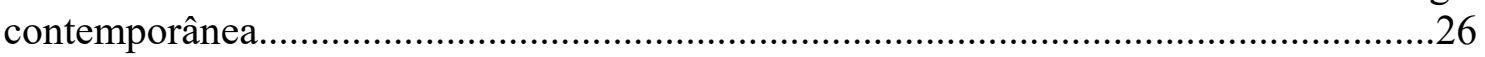

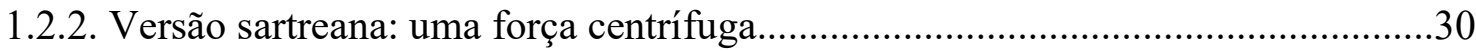

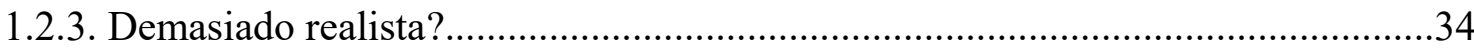

2. Renovação do sujeito: por uma consciência anônima...........................................39

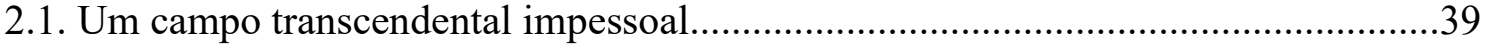

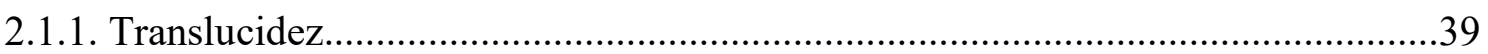

2.1.2. Um cogito pre-reflexivo; diálogos com Descartes e Kant....................................42

2.1.3. Autossuficiência: a unificação da consciência.....................................................48

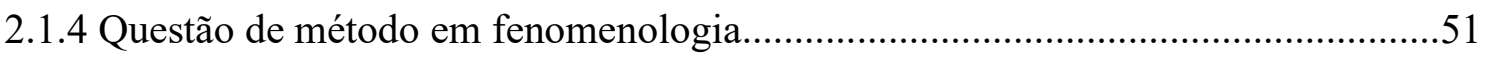

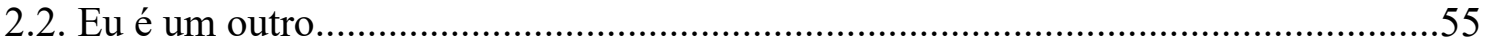

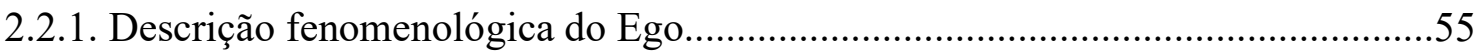

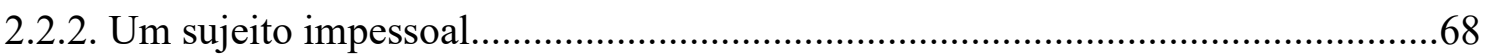

2.2.3. Negação do solipsismo: uma ética realista......................................................... 70

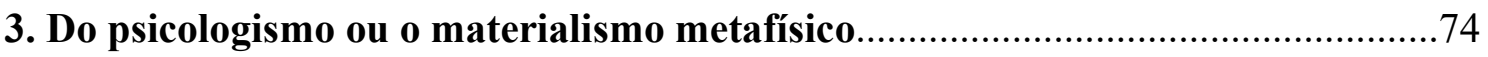

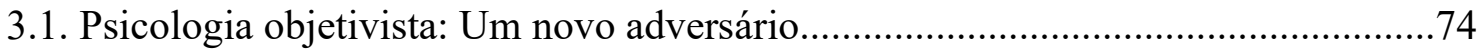

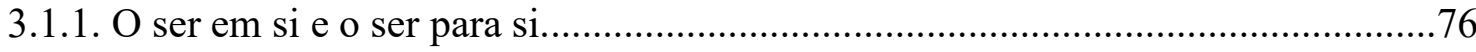

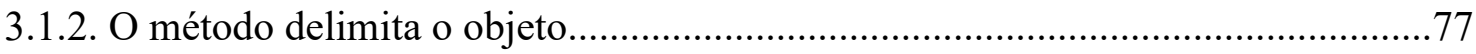

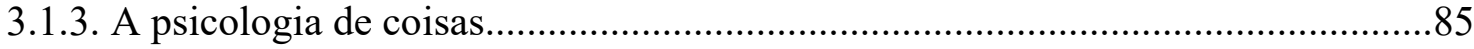

3.2. A intencionalidade da imagem e da emoção......................................................93

4. Do psíquico fenomênico; antessala do existencialismo ..........................................98

4.1. Esta terrível máscara japonesa: uma abordagem fenomenológica da emoção.........98

4.1.1. Para além do estado subjetivo: a emoção como uma transcendência....................99

4.1.2. Do mundo da magia: o ser humano é um feiticeiro............................................ 101 
4.1.2. Da consciência ativa: engajamento no mundo e lacuna teórica...........................106

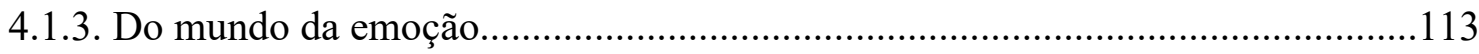

4.2. Ser-no-mundo: adentrando no existencialismo.....................................................119

4.2.1. Finalidade; espessura temporal da consciência.................................................119

4.2.2. A insustentável leveza do ser-no-mundo...........................................................123

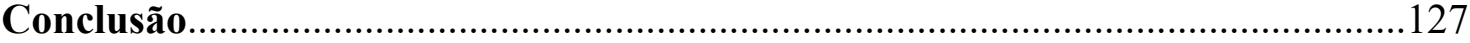

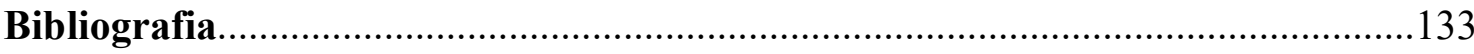




\section{Tabela de siglas das obras de Sartre:}

E. ou Emoções: Esquisse d'une théorie des émotions. Paris: Herman, 1975.

I. ou Intencionalidade: « Une idée fondamentale de la phénoménologie de Husserl: L'intentionnalité ». In Coorebyter, V. (ed). La transcendance de l'Ego et autres textes phénoménologiques. Paris: Vrin, 2003.

T.E. ou Transcendência do Ego: «La transcendence de l'Ego: Esquisse d'une description phénoménologique ». In Coorebyter, V. (ed). La transcendance de l'Ego et autres textes phénoménologiques. Paris: Vrin, 2003 


\section{Introdução}

Esta dissertação apresenta um estudo do conceito de consciência intencional nas obras do jovem Sartre. Pretende-se analisar as bases teóricas dessa noção e evidenciar suas implicações éticas para a filosofia do autor. O principal recorte desta pesquisa é constituído pelas obras sartreanas diretamente influenciadas pela fenomenologia de Husserl, o que compreende as produções realizadas pelo autor durante a década de 1930. Nessa fase, o filósofo francês desenvolve uma concepção fenomenológica da consciência, com a qual critica algumas linhas da filosofia e da psicologia de sua época (notadamente, as tendências que flertam com o dualismo entre consciência e corpo). Essas obras de Sartre são estudos críticos sobre epistemologia que aos poucos avançam na elaboração de uma teoria da consciência, e de suas relações com o mundo, que irão resultar na ontologia fenomenológica de $O$ ser e o nada. Pode-se dizer que toda a tensão conceitual da produção deste período está em torno dessa noção de consciência a ser disputada tanto com a fenomenologia do próprio Husserl, como com a psicologia. Sartre elabora sua concepção a partir do conceito de intencionalidade, segundo o qual a consciência se constitui num movimento de direcionamento ao mundo. O resultado disso é uma filosofia que imerge, ontologicamente, o sujeito no mundo, negando pela via epistemológica as posições solipsistas. Ao mesmo tempo, é uma filosofia da liberdade, pois afirma a espontaneidade da consciência que não pode ser mecanizada por nenhuma teoria psicológica de viés materialista.

Trata-se, portanto, de investigar como Sartre elabora as bases de sua filosofia e como esse estudo fenomenológico constituirá a fundamentação teórica das questões éticas e existenciais desenvolvidas ulteriormente pelo autor. Em outras palavras, esta pesquisa de mestrado se esforça para mostrar como a consciência intencional atua como o centro da filosofia do jovem Sartre, e como esse conceito se torna a base teórica do engajamento e da liberdade no existencialismo. Dessa forma, o presente estudo quer contribuir com a história da filosofia mostrando que antes de produzir livros como O Ser e o Nada e de se engajar nos debates que o tornaram famoso, Sartre já havia produzido todo um conjunto de obras que constituem uma fase própria de seu pensamento. Em outras palavras, existe um primeiro Sartre que pode ser encontrado em obras como o ensaio sobre $A$ transcendência do Ego e nos livros sobre a psicologia da imagem e da emoção, pois tais obras possuem um sistema próprio de ideias e questões. Sendo assim, esta dissertação 
pretende oferecer uma análise rigorosa da fase inicial de um autor de fundamental importância para a filosofia contemporânea.

Sabe-se que a fase existencialista de Sartre possui um volume considerável de comentários e de pesquisas sobre. Mas é apenas o exame da relação do autor com a fenomenologia que permite compreender com clareza a elaboração da ontologia fenomenológica de $\mathrm{O}$ Ser e o Nada; a obra que fundamenta o existencialismo. No entanto, a atenção dirigida para a primeira fase do pensamento desse autor é consideravelmente menor. Ainda assim, existem alguns trabalhos de comentadores muito consistentes, nos quais pretendemos nos apoiar e que serão oportunamente citados ao longo deste texto. A partir do embasamento fornecido por esses pensadores, esta pesquisa também pretende se inserir no debate sobre as obras do jovem Sartre. Nossa contribuição será a explicitação de como sua concepção de consciência impessoal e espontânea estabelece uma ponte teórica entre a epistemologia fenomenológica e a ética existencialista.

Seguindo o plano apresentado no projeto de pesquisa, dividi meu tema de estudos em dois momentos principais. No primeiro apresento o trabalho de "limpeza" da consciência realizado por Sartre. Com o conceito de intencionalidade, o autor pretende purificar a consciência de todos os conteúdos que a tradição dualista sempre a imputou. Esses conteúdos seriam as representações, as sensações, as paixões e até o próprio Eu. $\mathrm{Na}$ filosofia de Sartre, todos esses elementos "saem" da consciência e se transcendem no mundo. Esse é o momento de "defesa do realismo", no sentido de defender o estatuto do ser, independente do conhecer. Identifico tal desenvolvimento nas obras I. e T.E. O segundo momento conceitual desta pesquisa compreende as obras de psicologia fenomenológica; os dois livros sobre a questão da imagem e o tratado sobre as Emoções. Retenho dessas obras, principalmente, a crítica realizada ao psicologismo. Pois, a consciência descrita pela intencionalidade é um ente insubstancial e imaterial, portanto ela não pode ser vista da mesma forma que os entes naturais. Isso significa que ela não sofre causalidade; é absolutamente livre. Por isso, o autor critica os psicólogos que elaboram teorias mecanicistas sobre o funcionamento das emoções, segundo as quais, a consciência estaria submetida causalmente às alterações fisiológicas. Esse é o momento da defesa da autonomia da consciência.

Esta dissertação está, pois, dividida em duas partes que abordam, respectivamente, cada um dos momentos da obra do autor apontados acima. Cada uma 
dessas partes está, por sua vez, dividida em dois capítulos construídos por diferentes seções. Portanto, o corpo do texto é constituído por quatro capítulos, além desta introdução e de uma conclusão.

O primeiro capítulo se inicia apresentando o panorama do pensamento do jovem Sartre no momento em que este travou contato com a fenomenologia de Husserl. Com essa exposição eu quero mostrar que o autor não absorveu de maneira passiva a filosofia husserliana, pois ele já possuía um projeto filosófico bastante claro. Tal projeto determinou toda a recepção dos conceitos advindos da fenomenologia alemã. Nesse primeiro momento, minha intenção é evidenciar como Sartre constrói sua interpretação da fenomenologia no intuito de fundamentar as ambições éticas de sua própria filosofia. A seguir, exponho os resultados da leitura da obra husserliana dando destaque ao conceito de intencionalidade, pois além de ser um conceito chave da fenomenologia de Husserl, é também o conceito que mais chama atenção do autor francês que via nele uma possibilidade de renovação da epistemologia de sua época. Nessa exposição, trabalho principalmente com o curto artigo escrito por Sartre, resultado de sua estadia em Berlim, o Uma ideia fundamental da fenomenologia de Husserl: a Intencionalidade. Exponho, primeiramente, a descrição da consciência intencional advogada por Sartre no artigo, apontando as contribuições de Husserl, além das inovações trazidas pelo próprio filósofo francês. Em seguida, finalizo esse primeiro capítulo fazendo considerações sobre o caráter realista que Sartre confere ao conceito. Meu objetivo é mostrar que o autor interpreta o conceito husserliano com um caráter marcadamente realista para, com isso, poder refutar a posição idealista segundo a qual o ser do mundo objetivo estaria submetido ao conhecimento do sujeito cognoscente.

O segundo capítulo é dedicado, principalmente, ao ensaio A Transcendência do Ego: esboço de uma descrição fenomenológica. Trago a exposição dessa obra para dar continuidade ao tema iniciado no capítulo anterior, que vem a ser a purificação da consciência de todos os conteúdos subjetivos, já que em $I$. Sartre elimina do interior subjetivo as representações, as sensações e até as paixões. Segundo o autor, tudo se localiza no mundo transcendente. No ensaio sobre o Ego, ele continua esse trabalho, mostrando que nem mesmo a identidade pessoal pode habitar, a título de conteúdo, o interior da consciência. Começo mostrando como Sartre elabora, a partir de seu método fenomenológico, uma concepção impessoal da consciência. A partir de um debate com a filosofia crítica de Kant, o cogito de Descartes e o Eu puro de Husserl, Sartre defende a 
existência de um campo transcendental puro, despossuído de qualquer estrutura lógica ou formal que tenha os contornos de uma pessoalidade, e que determine sua relação com o mundo. O que o autor francês faz é estabelecer uma consciência completamente anônima que não necessita de nenhum recurso ao Eu para manter sua coesão interna. Em seguida, me dedico a acompanhar a definição realizada por Sartre do Ego como um ente transcendente à consciência. Essa exposição perpassa pela descrição da estrutura psíquica, composta por estados, qualidades e ações. Segundo o autor, o Ego é a síntese transcendente desses elementos, ou seja, é a síntese permanente do ser psíquico, objeto da consciência e ente mundano. Encerro esse capítulo fazendo considerações sobre como essa tese reformula a ideia tradicional de sujeito, pois a consciência anônima reclama para si características que eram exclusivas do Eu pensante. O sujeito impessoal de Sartre é um sujeito inerentemente comprometido com o mundo, pois, uma vez que o Ego é um objeto para a consciência, ele existe no mesmo registro que o mundo e dele retira todo seu conteúdo. Nesse sentido, a fenomenologia, entendida por Sartre, mostra-se uma filosofia engajada na realidade concreta; sua grande conquista teórica é a negação do solipsismo.

A partir do terceiro capítulo, adentro na segunda parte da pesquisa que aborda a constituição fenomenológica do ser psíquico. Inicio essa exposição apresentando a crítica sartreana à psicologia. Pautado pela concepção de consciência conforme foi descrita nas obras anteriores, Sartre passa a dedicar sua atenção aos problemas teóricos que a psicologia objetivista desenvolvida entre o final do século XIX e início do XX apresentava. Em linhas gerais, esses problemas advinham de uma concepção materialista da consciência, segundo a qual ela seria constituída por reminiscências da percepção. Assim, a imagem mental seria apenas uma impressão sensível menos intensa e as emoções seriam o resultado, ou a mera expressão de alterações fisiológicas. Para combater essas teses, o filósofo propõe a elaboração de uma psicologia fenomenológica da imagem e da emoção.

Esse estudo do final dos anos 30 se encontra nos livros $A$ Imaginação, $O$ Imaginário e no Esboço para uma teoria das emoções. No terceiro capítulo tento trabalhar, de forma simultânea, com A Imaginação e E., pois, segundo minha interpretação, existe um importante conteúdo comum nessas obras, a supracitada crítica ao psicologismo. Embora em cada obra essa crítica seja realizada por um motivo diferente (respectivamente, para a proposta de uma concepção fenomenológica da imagem e da emoção), há um ponto no qual ambas as críticas convergem; o combate ao objetivismo 
de viés positivista, que identifica o modo de ser da consciência com o das coisas materiais. Desse modo, exponho a análise sartreana de certas psicologias desenvolvidas entre os séculos XIX e XX para explicitar o projeto maior que perpassa essas críticas; o combate ao realismo metafísico que mecaniza e reifica a subjetividade. Em outras palavras, a crítica de Sartre à psicologia é parte do percurso filosófico de afirmar a autonomia da consciência que, por imperativos ontológicos, é indeterminada e espontânea. Uma vez apresentado esse debate com a psicologia, termino o terceiro capítulo expondo a concepção sartreana da imagem mental e da emoção. De acordo com o princípio de intencionalidade conforme estudado nas obras anteriores, esses elementos psíquicos, como toda forma de consciência, serão identificados com uma transcendência, correlatos mundanos da consciência; mais uma maneira pela qual a consciência escapa de si e encontra o mundo.

O quarto e último capítulo desta dissertação irá se aprofundar, mais detalhadamente, no livro sobre as Emoções. A atenção especial dedicada a essa obra ocorre porque, conforme pretendo mostrar, nela Sartre sofistica sua concepção de consciência intencional, reavaliando algumas dificuldades teóricas que restaram das obras anteriores. Sobretudo, as inovações conceituais concernem à questão da temporalidade. A consciência descrita em I. e T.E. era uma entidade extremamente transparente e espontânea; um fenômeno que se esgotava em sua própria aparição. Essa era a fundamentação da característica de translucidez que Sartre atribuía à consciência e, com a qual, recusava sua naturalização através da presença de conteúdos como a percepção sensível e o Ego. Entretanto, essa translucidez só era atestada pela evidência adquirida através da reflexão pura, que aceitava apenas os dados da consciência instantânea que brotava ex nihilo. O resultado de um critério tão rigoroso condenava a teoria de Sartre a uma filosofia do instante, de modo que a consciência existiria na forma de sucessivos instantes congelados. Era impossível conceber um fluxo temporal. No entanto, em E. o autor reconsidera o status do ser psíquico, fazendo dele uma modalidade constituinte da consciência espontânea. A partir dessa reconsideração, será possível conceber uma noção temporalizada da consciência, pois o psíquico se relaciona com o mundo através de protensões emocionais, portanto, numa espessura temporal. Para apresentar esses enriquecimentos teóricos, dedicarei boa parte do último capítulo para expor detidamente a análise fenomenológica da emoção. Finda essa análise, a consciência será vista como um ser que não apenas explode em direção ao mundo, mas o faz de forma interessada e 
de posse de projetos pautados pela finalidade constituída pela subjetividade. Sendo assim, mais do que mera abertura fenomênica, a consciência intencional desenvolvida em $E$. é uma subjetividade radicalmente impessoal e livre, o fundamento do sujeito descrito pelo existencialismo, que supera e ultrapassa sua situação, através de seu poder nadificante, predicado de sua liberdade. A partir de então, dedicarei as últimas páginas da dissertação para, a partir dessa concepção de sujeito, explanar sobre as implicações éticas da fenomenologia sartreana. Sabe-se que o próprio Sartre jamais desenvolveu uma ética sistematizada, entretanto um impulso ético perpassa por todo esse projeto desenvolvido ao longo dos anos 30. Dessa forma, as últimas considerações desta pesquisa não pretendem analisar algo que o próprio autor nunca fez, mas, tão somente, fazer apontamentos nesse sentido, mostrando como a concepção fenomenológica da consciência é, para Sartre, a fundamentação ontológica da negação do solipsismo (o que implica em engajamento) e da indeterminação da subjetividade (o que implica na liberdade do ser humano em situação). 


\section{A Consciência intencional no jovem Sartre: bases fenomenológicas e perspectivas éticas.}

\section{Primeira parte: “A presença do mundo tal qual se dá a nós”.}

\section{Purificação da consciência transcendental: combate ao idealismo}

\subsection{Le Bec de Gaz}

Oh! La Science! On a tout repris. Pour le corps et pour l'âme, - le viatique, on a la médicine et la philosophie, - les remèdes de bonnes femmes et les chansons populares arrangées. (RIMBAUD, A. "Mauvais sang", In Une saison en enfer)

É comum que os comentários sobre o jovem Sartre se iniciem com a anedótica história da primeira vez em que o filósofo ouviu falar sobre a fenomenologia de Husserl. O relato não varia muito: no início de 1932, Sartre e Simone de Beauvoir estavam em um bar parisiense, chamado Le Bec de Gaz, encontrando-se com um antigo colega normalien, ninguém menos que Raymond Aron. Este último acabara de voltar de um intercâmbio na Alemanha pelo Instituto francês. Lá, ele entrara em contato com a filosofia alemã, notadamente a fenomenologia de Husserl, a qual relatava para Sartre. Essa exposição não se tratava apenas de um curioso relato de viagem, aparentemente a fenomenologia ia de encontro às ambições filosóficas sartreanas. Beauvoir é quem nos conta como foi o evento: "vês meu camaradinha, se tu és fenomenólogo podes falar sobre este coquetel na mesa e isso é filosofia". Segundo o relato, Sartre empalideceu - ou quase - de emoção ao ouvir o antigo colega. A exposição de Aron foi impactante o suficiente para fazer Sartre adquirir, logo em seguida, o livro do francês Emmanuel Levinas sobre fenomenologia; $A$ teoria da intuição na filosofia de Husserl, o qual foi folheado ainda no caminho para casa.

\footnotetext{
${ }^{1}$ BEAUVOIR, S. La force de l'âge. Apud. COOREBYTER, V. Sartre face à la phénoménologie. Bruxelas: Ousia, 2000. p. 11.
} 
E a consequência mais duradoura desse encontro foi a ida de Sartre para a Alemanha no ano seguinte, substituindo o colega na vaga do Instituto francês, no intuito de conhecer mais de perto a filosofia de Husserl.

Por mais anedótica que seja a história, existem motivos para ela ser repetida tantas vezes pelos comentadores. O fato é que o relato traz dados muito importantes sobre a recepção sartreana da fenomenologia, além disso nos ajuda a compreender o tema diretor que moveu o pensamento do autor durante a produção de suas obras filosóficas da década de 30 .

Quando Aron falava sobre fazer filosofia a partir de um copo na mesa, ele se referia ao conceito de intencionalidade. Esse conceito fundamental da escola filosófica inaugurada por Husserl, permite descrever um objeto prosaico como um coquetel de abricot e, a partir disso, tirar uma série de consequências filosóficas. Uma vez que a atenção de Sartre estivesse imersa naquele objeto sobre a mesa, ele poderia descrever as infindáveis maneiras pelas quais o objeto se doava à sua percepção naquele momento e chegar à seguinte conclusão: aquele objeto era um fenômeno para sua consciência, e sua consciência, no exato momento em que se entregava à apercepção do objeto, era uma consciência-de-coquetel sobre a mesa. Eis aí a possibilidade do desdobramento de uma série de investigações. E tais desdobramentos não apareceriam se Sartre se questionasse sobre como sua consciência teria acesso ao copo que lhe era exterior, ou como tal objeto poderia se transformar em representação em seu espírito. Ao contrário, o que Aron demonstrava é que era possível implicar certas consequências filosóficas tratando aquele objeto na forma mais direta pela qual ele aparecia naquele momento, como um coquetel de abricot sobre uma mesa, em um bar chamado Le Bec de Gaz, diante de três jovens filósofos. Com a fenomenologia, era possível filosofar sobre um objeto sem tratá-lo como uma representação subjetiva, uma idealidade, ou uma entidade metafisicamente separada do sujeito. Numa epifania digna de um Alberto Caeiro, um coquetel sobre a mesa era simplesmente um coquetel sobre a mesa; um ser do mundo contextualizado em seu horizonte, tal como ele se entregava para aquelas consciências; um fenômeno. Sartre percebe que a intencionalidade afirma a coincidência entre o ser e o aparecer das coisas.

Essa interpretação realista do conceito de intencionalidade, sendo fiel ou não ao espírito da filosofia husserliana, de fato ia de encontro com o que Sartre buscava na época. Formado há alguns anos na École normale supérieure, o jovem filósofo já possuía suas 
próprias ambições e questões filosóficas, as quais vinha trabalhando em suas obras literárias. O tema existencial da contingência, por exemplo, já era uma de suas grandes preocupações e é desenvolvido em um poema intitulado $A$ árvore - que, infelizmente, não conseguimos localizar - e no famoso romance $A$ Náusea $^{2}$. Além disso, as obras autobiográficas tanto do próprio Sartre, quanto de Beauvoir, dão testemunhos importantes sobre os temas que moviam o pensamento do jovem autor. "Eu tinha horror dos diários íntimos e pensava que o homem não é feito para se ver, mas que ele deve sempre fixar seu olhar para diante de si." 3 . Tal afirmação caracteriza um dos traços mais gerais do pensamento do jovem Sartre; uma aversão, quase que militante, ao subjetivismo contemplativo. Tal aversão não é gratuita e pode ser compreendida se observarmos o contexto da formação do filósofo. O ambiente intelectual francês do início do século XX era predominantemente marcado pelas correntes espiritualistas. Autores como Brunschvicg, Lalande e Meyerson eram referências do cenário filosófico de então e, para Sartre, representavam o pensamento idealista do período. Até a filosofia dualista de Bergson e a literatura introspectiva de Proust são identificados por Sartre como sintomas do idealismo francês. Para o jovem filósofo, esse cenário significava que a filosofia francesa não se ocupara com mais nada, nos últimos cem anos, além da epistemologia idealista. Em tom pejorativo, ele chama essas correntes de pensamento de filosofia alimentar, uma filosofia que entende o processo do conhecimento como absorção dos objetos do mundo pela consciência, transformando-os em representações. Assim, não conheceríamos as coisas, mas apenas a representação subjetiva que delas fazemos. Para Sartre, isso significaria que nunca temos acesso ao mundo real. A consciência viveria encerrada na dimensão de suas próprias representações e, não sendo aquele objeto adiante mais do que um conjunto de sensações, ele não seria propriamente um objeto, mas sim um ente feito da própria matéria subjetiva. O mundo seria dissolvido dentro da consciência num processo no qual, ao fim, nada restaria além do próprio sujeito cognoscente.

\footnotetext{
${ }^{2} \mathrm{Em} A$ árvore, o jovem autor teria comparado o padrão aleatório do crescimento dos galhos e ramos do vegetal com a contingência inerente à própria realidade, que apenas vai acontecendo sem nenhuma ordem pré-determinada ou objetivo final. Em $A$ Náusea, a existência contingente atravessa a vida do protagonista que a sente na forma de um mal-estar existencial. Além disso, como citarei mais adiante, alguns resultados do estudo sobre Husserl também aparecerão no romance. A experiência da consciência impessoal e livre de conteúdos (resultados da descoberta da intencionalidade) se juntará às conclusões de Roquentin sobre a característica nauseante da existência.

${ }^{3}$ SARTRE, J.P. Carnets de Drôle de Guerre, p. 351-52. Apud. COOREBYTER, V. Sartre face à la phénoménologie. Bruxelas: Ousia, 2000. p. 39.
} 
Para Sartre, o idealismo produzia um mundo mole e incerto, sem nada para se engajar, apenas uma "sopa subjetiva". E o desentendimento deste autor com o idealismo ia muito além da epistemologia, tratava-se de uma questão ética. O jovem filósofo via nesse espiritualismo um convite ao quietismo, a um afastamento do mundo real que se traduziria numa apatia social e política. Pois segundo essas correntes, poder-se-ia dizer que o mundo e, portanto, seus problemas reais, como a guerra e a fome, não passariam de eventos relativos à consciência. Objetos para serem meticulosamente absorvidos e digeridos por lentos processos subjetivos. A postura prática do idealismo incomodava Sartre tanto quanto, ou até mais, que suas posições teóricas: "Eu era realista por moral"4.

Mas o pensamento de Sartre não funcionava apenas por reação e, além de recusar o idealismo, ele também tinha sérias ressalvas quanto ao total oposto, um materialismo absoluto. Do mesmo modo que o autor não acreditava que o mundo material pudesse ser transfigurado em ideia, a partir da representação, ele também não via como a consciência poderia sofrer causalidade por parte da matéria, sendo tratada, assim, como um objeto dentre outros. Por essa razão, o filósofo também estava atento à ciência positivista de sua época e via nela uma perigosa tendência para algo que ele chama de materialismo metafísico. Ou seja, uma teoria que afirmasse que a matéria física é a única substância do universo. $\mathrm{O}$ mundo regido pela causalidade física seria absoluto e a consciência estaria inserida nesse sistema como qualquer outro objeto. Para esse materialismo, o processo do conhecimento seria descrito pela atividade de causa e efeito, a matéria do mundo causando reações fisiológicas no sujeito e esse efeito seria traduzido como a representação na consciência. A subjetividade humana, enquanto tal, estaria erradicada desse sistema. Sartre via tal tendência principalmente no que concerne à psicologia experimental. Suas ressalvas incidiam sobre teorias psicológicas que investigavam a emoção apenas observando as reações fisiológicas, ignorando as dinâmicas da subjetividade. É por isso que o autor buscava fundamentar um realismo que assegurasse a realidade dos objetos mundanos, mas que não desembocasse num materialismo que eliminasse a subjetividade, tratando a consciência como um ente submetido à causalidade material. Essa ressalva para com o materialismo é, inclusive, o mesmo problema pelo qual Sartre polemizaria com os marxistas anos mais tarde. Uma vez que o filósofo não via como o ser humano poderia ser inteiramente determinado pelas condições materiais e econômicas, muitos marxistas consideraram sua filosofia incompatível com o

\footnotetext{
${ }^{4}$ Idem nota 3, p. 86.
} 
materialismo dialético, acusando-a de ser um subjetivismo burguês. Por essa razão, Sartre dedicará vários trabalhos para mostrar como o existencialismo vai de encontro aos ideais revolucionários, pois, segundo ele, um verdadeiro realismo não necessita de uma teoria quase que metafísica ${ }^{5}$ como o materialismo e, considerar a ação da subjetividade no processo histórico em nada prejudicaria a compreensão de uma verdadeira dialética entre as necessidades materiais e a atuação humana no mundo natural e social.

Todo esse quadro de preocupações filosóficas formava o contexto do pensamento sartreano quando do encontro com Aron. Era um pensamento profundamente interessado pela epistemologia, pelas relações da consciência com o mundo. Por sua vez, essa epistemologia não era neutra, pois tinha uma inclinação ética latente: assegurar uma postura ativa no mundo com a recusa da contemplação subjetiva do idealismo e, ao mesmo tempo, ter o cuidado de não mecanizar o ser humano, a partir de uma compreensão naturalista da consciência. O jovem filósofo que se encontrava no Bec de Gaz possuía, mais ou menos definidamente, este projeto filosófico: constituir uma teoria epistemológica e ontológica que fundamentasse sua ética de engajamento e de liberdade ${ }^{6}$. Essa epistemologia deveria superar os impasses entre o idealismo e o realismo, pois ambas as teorias compartilhavam a tese da cisão, quando não da oposição, entre a consciência e o objeto, leia-se, entre o sujeito e o mundo. É então que a fenomenologia surge para o jovem filósofo que reconhece nela uma teoria capaz de liquidar com essa antiga disputa epistemológica. O que Sartre vê inicialmente na fenomenologia, que julga capaz de atender aos seus objetivos, é o supracitado conceito de intencionalidade. $\mathrm{O}$ mesmo conceito que era capaz de extrair filosofia da exposição sobre um coquetel, era também capaz de fornecer uma via epistemológica que superasse a cisão entre consciência e mundo das teorias que Sartre almejava combater. O autor identifica essa possiblidade aberta pelo conceito por conta da contemporaneidade entre consciência e objeto que ele estabelece. Portanto, uma escola de pensamento fundamentada numa noção tão sofisticada deveria fornecer caminhos muito fecundos para a filosofia que o autor

\footnotetext{
5 Vale frisar que Sartre nunca se posicionou contra o materialismo dialético, mas sim contra uma interpretação exagerada dessa linha de pensamento que tendia a eliminar a subjetividade afirmando a absoluta soberania da matéria sobre a ideia. Para Sartre, um materialismo assim concebido teria os contornos de uma metafísica e não de uma teoria histórico-social: "Eu compreendo, agora, que o materialismo é uma metafísica dissimulada sob um positivismo. Mas é uma metafísica que destrói a si mesma, pois, minando por princípio a metafísica, ela elimina todo fundamento de suas próprias afirmações." (SARTRE, 1990, p. 84.).

6 "Se nos atentarmos à concepção que Sartre possui da consciência, é quase um lugar comum afirmar que a ontologia não poderia se separar da ética.” (JOANNIS, 1996, p. 8.)
} 
francês almejava constituir. Como lembra Beauvoir: "a fenomenologia respondia exatamente às suas preocupações: ultrapassar a oposição do idealismo e do realismo, afirmar a um só tempo a soberania da consciência e a presença do mundo, tal como se dá a nós"7. Esta citação pode ser tida como a síntese máxima do projeto sartreano que esta pesquisa quer expor, por essa razão, o corpo desta dissertação é separado em duas grandes partes cujos títulos fazem menção aos dois momentos do projeto; afirmar a presença do mundo e defender a soberania da consciência, respectivamente.

Com esta exposição do panorama do pensamento do jovem Sartre, quero mostrar que o encontro do filósofo com a fenomenologia não foi, simplesmente, a descoberta de uma novidade da filosofia alemã. O que Sartre vislumbra, ainda durante a exposição de Aron, é a possibilidade de encontrar um caminho teórico que fundamente sua própria filosofia, essa é a causa do entusiasmo do jovem autor durante a conversa com o colega naquele bar parisiense. Sartre já possuía os contornos de seu próprio projeto que esperava poder desenvolver a partir das possibilidades teóricas e metodológicas da fenomenologia husserliana. Por essa razão, os historiadores da filosofia têm dificuldade em catalogar as primeiras obras de Sartre como parte comportada da bibliografia fenomenológica. Ainda nos primeiros textos que o autor francês dedica quase que como homenagens a Husserl, as disparidades com a filosofia do mestre são evidentes. Alguns conceitos são interpretados num enfoque muito diferente do original, e a maneira como Sartre ignora outros temas husserlianos é quase que uma crítica velada à filosofia de Husserl. Isso sem falar das várias críticas explícitas ao antigo mestre que são encontradas desde as primeiras obras. Todos esses detalhes são evidências de que a recepção sartreana da fenomenologia não se trata do acolhimento passivo de uma nova filosofia, mas, ao contrário, foi a adaptação de um método teórico para os fins de uma ambição fillosófica que já estava presente no Bec de Gaz. Esse projeto, creio, encontra sua expressão mais clara e sintética no já citado relato de Beauvoir "afirmar a um só tempo a soberania da consciência e a presença do mundo, tal como se dá a nós”. Como já foi dito, é uma ambição dupla, conferir realidade objetiva ao mundo, concomitantemente à autonomia da consciência. Essa ambição vai se cumprir ao longo das obras selecionadas como o recorte desta pesquisa; as produções de Sartre sobre fenomenologia da década de 30. Esse projeto duplo é o tema diretor que perpassa por todas essas obras, às vezes de maneira mais ou

\footnotetext{
${ }^{7}$ BEAUVOIR, S. La force de l'âge. Apud. COOREBYTER, V. Sartre face à la phénoménologie. Bruxelas: Ousia, 2000. p. 23.
} 
menos clara, às vezes com cada um dos temas sendo tratados de maneira separada e outras de modo mais imbricado. Por exemplo, num texto que deveria ser apenas a descrição da consciência como o artigo da Intencionalidade, Sartre também se dedica a afirmar a realidade objetiva do mundo. No esboço das Emoções, a descrição da vida psicológica tem o intuito de atestar a impossibilidade de a consciência ser tratada como um ente mecanizado. Já em $A$ Transcendência do Ego, a realidade objetiva e a não naturalização da consciência são temas indissociáveis.

Enfim, esta primeira seção foi dedicada a apresentar o panorama do pensamento de Sartre pre-estadia em Berlim para mostrar que sua recepção da fenomenologia só pode ser lida nas perspectivas de seu próprio projeto filosófico. Repito, é um projeto caracterizado por uma investigação epistemológica de inspiração ética. Sem essas perspectivas, os trabalhos sartreanos de psicologia fenomenológica e de ontofenomenologia poderiam ser vistos apenas como uma leitura exótica da filosofia de Husserl. Mas, como será mostrado nas próximas páginas, essas obras se tratam de uma recepção consciente de seu objetivo, nas palavras do comentador belga Vincent de Coorebyter, este objetivo seria o de estabelecer "contra o mundo desencantado das ciências, e o universo inconstante das filosofias idealistas, um mundo plenamente humano e saturado de sentido" (COOREBYTER, 2000, p. 12).

\subsection{A intencionalidade: entre a herança fenomenológica e o apelo realista.}

Penso com os olhos. E com os ouvidos. E com as mãos e os pés. E com o nariz e a boca. Pensar uma flor é vê-la e cheirá-la. E comer um fruto é saber-lhe o sentido (Alberto Caeiro, "Poema IX" de $O$ guardador de rebanhos)

Após o encontro com Aron, Sartre passa todo um ano letivo em Berlim (setembro de 33 a junho de 34) estudando a fenomenologia. Foi um período intenso de trabalhos, dedicando apenas o período da manhã para a leitura de Husserl (as tardes eram reservadas para a revisão de $A$ Náusea), o jovem francês estudou a fundo, nesse pouco tempo, as Meditações Cartesianas, Investigações Lógicas e Ideias para uma fenomenologia pura e para uma filosofia fenomenológica (doravante Ideias I), além de iniciar a leitura de Heidegger. Segundo o comentador Coorebyter (2003) foi, provavelmente, durante o final dessa estadia que o jovem Sartre escreveu o artigo da Intencionalidade e o ensaio sobre A Transcendência do Ego, apesar de ambos só terem sido publicados alguns anos mais 
tarde e em datas diferentes. Apesar de ter sido publicado por último, $I$. parece ser o ponto de partida para o estudo dessa fase do pensamento sartreano. Em tom de manifesto, esse curto artigo é, de fato, seminal para a filosofia do autor, pois ele traz as bases conceituais das obras seguintes e algumas teses que serão mantidas por toda a carreira do filósofo. Nesse texto, Sartre se propõe a apresentar o cerne da filosofia de Husserl para o público francês, por isso a escolha do conceito de intencionalidade. Mas como já foi dito, a fidelidade de Sartre como discípulo deve ser vista com cuidado. O interessante desse texto é que nele, apesar dos vários elogios a Husserl, Sartre termina a exposição do conceito apontando para consequências nada evidentes na obra do filósofo alemão. Para o autor francês, a intencionalidade, além de fornecer a descrição da consciência, implica numa teoria filosófica na qual tudo está fora dela, os objetos, as verdades matemáticas, as emoções e as paixões, tudo. Sartre estabelece uma definição na qual a consciência é um vazio absoluto diante de um mundo plenamente carregado de sentido, o mundo "dos artistas e poetas" ${ }^{8}$ cuja restituição ele atribui a Husserl. O teor realista da leitura sartreana é evidente. Nesta seção pretendo explorar essa leitura do conceito de intencionalidade, pois esse conceito que é, de fato, o fundamento da fenomenologia, determina todos os desdobramentos conceituais efetuados por Sartre ao longo de sua fase fenomenológica. As diferenças do conceito na visão do mestre e do discípulo, que pretendo citar brevemente, evidenciam os objetivos do projeto sartreano exposto na seção anterior.

1.2.1. Breve histórico do conceito: da filosofia escolástica à fenomenologia contemporânea ${ }^{9}$.

A origem da noção de intencionalidade se remete à filosofia medieval. Os escolásticos utilizavam o termo para referirem-se à propriedade dos seres mentais de estarem sempre referenciados para algo. A etimologia da palavra é latina. Intentio, variação de intendere que significa tender a, voltar-se para algo, direcionar-se. Portanto, diferentemente do uso contemporâneo de palavras com as raízes de intenção/intencionar, intencionalidade não se refere a um ato volitivo, mas sim a um ato de direcionar. A direção da qual se fala é a da atenção da mente para os seus objetos.

\footnotetext{
${ }^{8}$ SARTRE, J. P., Idem, p.89.

${ }^{9} \mathrm{O}$ intuito desta seção é apenas apresentar, de forma introdutória e breve, o percurso histórico do conceito. Para manter o foco temático do texto, não pretendo me aprofundar nem na filosofia escolástica nem na de Brentano.
} 
O primeiro contemporâneo a retomar esse conceito dos escolásticos é Franz Brentano. Numa formulação bastante simplificada, pode-se dizer que, com o filósofo germânico, intencionalidade passa a tomar os contornos de um conceito fundamental para as filosofias do espírito. Ela se torna o critério para distinguir os fatos psíquicos dos físicos. Pois, para Brentano, a característica particular dos fatos psíquicos, que os distingue dos físicos, é, justamente, de serem intencionais. Isso significa que todo evento psíquico se direciona para algo, se refere a alguma coisa que não a própria consciência; possui um objeto. Essa característica é compartilhada por todos os tipos de fenômenos psíquicos, sejam perceptivos, volitivos, judicativos, imaginários, etc. Disso decorre que não apenas aos objetos materiais e "exteriores" a consciência se reporta intencionalmente, mas a todos os tipos de objetos. Por exemplo, é fácil supor que quando tenho a percepção visual de uma árvore, minha consciência intenciona essa mesma árvore como seu objeto. Mas esse mesmo ato de intencionar pode ocorrer com outras coisas que não existam, necessariamente, no "mundo exterior". Quando imagino Pégaso, ou penso em algum número, também nestes casos a consciência intenciona esses objetos como algo distinto dela mesma. Apesar de não serem exteriores ao sujeito, eles são intencionados como existentes do mundo, quase como se existissem "realmente". O que importa destacar é esta propriedade da consciência de, nesses casos, estar atenta, estar voltada para algo que não ela própria. Sua propriedade de, em todos os casos, e em todos os seus tipos de ocorrência, ter um objeto. Isto é intencionalidade; a propriedade da consciência de estar sempre voltada para algo. Para Brentano, essa propriedade caracteriza todos os fenômenos mentais. É daí que vem sua célebre formulação que irá se tornar como que um refrão da fenomenologia; toda consciência é consciência de um objeto e todo objeto é objeto para uma consciência.

Edmund Husserl, que foi aluno de Brentano, retoma o conceito do antigo professor e o transforma no fundamento de sua nova escola de pensamento. Mas a fenomenologia husserliana vai muito além da fórmula toda consciência é consciência de algo... e, através de sua metodologia de pensamento, vai aprofundar continuamente a definição desse conceito. As análises husserlianas chegam ao ponto de definir a intencionalidade como uma característica eidética da consciência. Eidética, pois é encontrada após a redução de mesmo nome. O procedimento dessa redução eidética é o seguinte. A partir do exercício imaginário, variam-se diversos casos de um evento particular. Repete-se este procedimento com o maior rigor e em quantas vezes for preciso. A característica que 
permanece em todos os casos, após diversas variações, é uma característica eidética do ser em questão.

Após a colocação da realidade do mundo entre parênteses, realizada pela redução fenomenológica ${ }^{10}$ chamada de epoché, o que resta são os objetos da consciência. Ou, de maneira mais ampla, os vividos da consciência. Eu posso supor que aquela árvore que vejo nem exista de fato, mas, sendo ela ilusão ou não, é inegável que tenho consciência da árvore. Portanto esta árvore, enquanto vivido de consciência, possui uma existência irrefutável. O mundo, após a redução, torna-se o fluxo dos vividos da consciência. Eis aqui o escopo da fenomenologia; investigar e descrever esses vividos. E para desvelar suas essências, usa-se a redução eidética. Aplicando tal redução no fluxo dos vividos, Husserl constata que alguns aspectos sempre os acompanham. A temporalidade, por exemplo, é o aspecto mais absoluto. Pois todo vivido se dá em um fluxo. O fluxo, por sua vez é sempre temporal. Uma vez que, para que se tenha consciência, é necessário que se tenha um vivido que transcorra nesse fluxo, pode-se afirmar que a temporalidade é uma estrutura eidética da consciência. Ou seja, o tempo enquanto aspecto invariável de todos os vividos é determinado como aspecto essencial da consciência. É da essência da consciência ser temporal. Com a intencionalidade ocorre o mesmo. Pois toda a forma de consciência, que se possa variar, terá sempre um objeto. Em todas as suas modalidades, a consciência é sempre consciência de algo. Disso se conclui que a intencionalidade é uma estrutura eidética da consciência. É verdade que Husserl afirma que nem todo vivido possui, propriamente, um objeto. Por exemplo, ao ver uma folha de papel, posso afirmar que a folha seja meu objeto. Mas tenho, também, o sentimento da percepção de sua cor, sua brancura. Apesar de ser um vivido, a brancura não é, necessariamente, um objeto, pois ela não se refere a nada. Assim, este tipo de vivência sensível pode habitar passivamente minha consciência. Esse dado sensível puro, essa carne do mundo que me é imanente, é o que Husserl chama de hylé. A hylé, enquanto passividade, não tem objeto

\footnotetext{
${ }^{10}$ É preciso dizer que as reduções fenomenológica e eidética não são elaboradas simultaneamente pelo autor. Husserl aperfeiçoa e revê constantemente sua própria obra, e vários tipos de reduções são formuladas em momentos diferentes, para fins distintos, apesar de que, às vezes, elas possam cooperar. Quanto a estas citadas, por exemplo, a redução fenomenológica foi desenvolvida primeira pelo autor, e seu procedimento de suspensão da validade ontológica da transcendência já era utilizado desde as Investigações Lógicas, embora nessa obra ainda não houvesse a redução propriamente dita, mas apenas um procedimento semelhante. Esse livro, por sinal, foi muito bem lido por Sartre que teve muito mais acordo com as teses aí expostas do que com aquelas do posterior Ideias I (que é onde Husserl elabora, verdadeiramente, sua filosofia transcendental e as reduções próprias a esse tema), obra na qual se utiliza a redução eidética. Como a exposição que faço aqui da filosofia de Husserl é muito modesta e geral, tomei a liberdade de apresentar o resultado simultâneo das duas reduções, apesar de não se passar necessariamente assim na obra do filósofo.
} 
definido, é uma vivência não intencional. Por outro lado, isso revela algo importante. Uma vez passivo, o vivido não é propriamente consciência de nada. Isso significa que toda vez em que haja um ato da consciência, o vivido passa a ser seu objeto, objeto de consciência. Disso se conclui que há algo de atividade nesta forma consciência de algo. Logo, pode-se afirmar que toda a consciência é uma ação de visar os objetos. A esta ação se dá o nome de intencionalidade. Consequentemente, a intencionalidade é encontrada como uma estrutura eidética da consciência ${ }^{11}$. Isto é, a intencionalidade é uma característica invariante de toda ocorrência consciente. Como Husserl já diz no parágrafo 36 do livro de Ideias $I$, a intencionalidade não tem a ver com a relação de um evento psicológico qualquer com um objeto existente. Mas sim, com puras essências dos vividos. Isso significa que este conceito não concerne apenas à facticidade do vivido no mundo, mas é um aspecto essencial do próprio ser da consciência.

A partir daqui, Husserl começa a ir além da antiga fórmula toda consciência é consciência de alguma coisa. No parágrafo 87 de Ideias I ele até ironiza essa simplicidade alertando para os "caminhos labirínticos" para os quais a reflexão atenta dessa fórmula pode levar ${ }^{12}$. Após um rigoroso procedimento epistemológico, a intencionalidade é encontrada como uma característica essencial da consciência, uma ação que ela realiza, necessariamente, sobre seus vividos. Explorando mais a fundo essa ação, Husserl chegará na correlação noético-noemática. Tais termos são os dois polos de uma estrutura que descreve o próprio funcionamento da intencionalidade. Noese é o que Husserl chama de imanência "interna", pois refere-se ao ato da consciência sobre o objeto intencionado, esse ato pode ser perceptivo, volitivo, judicativo, etc. Quanto ao noema, ele é o que Husserl chama de imanência "autêntica", o termo se refere ao fenômeno que está sendo intencionado, é o que sobra do objeto após a redução; um núcleo de sentido. Ou seja, a noese é o polo subjetivo da experiência, enquanto que noema é o polo objetivo. Ambos os termos estão sempre, essencialmente, correlacionados, pois são parte de um mesmo processo. Por meio dessa correlação, a consciência anima seus conteúdos hiléticos a fim de ultrapassá-los e visar seu objeto enquanto núcleo de sentido. Portanto, para Husserl, o conceito de intencionalidade significa muito mais do que afirma a fórmula escolástica

\footnotetext{
11 “A intencionalidade é aquilo que caracteriza a consciência no sentido forte, e que justifica ao mesmo tempo designar todo o fluxo de vivido como fluxo de consciência e como unidade de uma única consciência" (HUSSERL, 2006, p.190)

12 "A peculiaridade do vivido intencional é facilmente designada em sua generalidade; todos nós entendemos a expressão 'consciência de algo' (...) Tanto mais difícil, porém, é apreender pura e corretamente as peculiaridades fenomenológicas de essência a ela correspondentes.” (Idem, p. 201).
} 
toda consciência é consciência de algo. Neste autor, a intencionalidade é o nome de um complexo procedimento epistemológico no qual a consciência pura atua sobre suas vivências a fim de constituir o mundo objetivo enquanto sentido noemático. Intencionalidade, para Husserl, descreve uma ação subjetiva e transcendental.

Apresentarei, agora, os resultados da leitura que Sartre faz da intencionalidade. Tais resultados estão expostos no supracitado artigo $I$. Como veremos, com a intenção de destacar o sentido realista do conceito, o autor francês prioriza sua versão escolástica e dela implica conclusões quase que ontológicas sobre a realidade objetiva das coisas. Esse procedimento só poderá ser realizado ignorando algumas teses husserlianas de Ideias I.

\subsubsection{Versão sartreana: uma força centrífuga}

No artigo "Uma ideia fundamental da filosofia de Husserl: a intencionalidade", Sartre realiza uma exposição generosamente imagética desse conceito. Intencionalidade significaria uma explosão, um escorregar para fora de si, um grande vento. Em linhas gerais, o autor francês enfatiza a característica de movimentação para fora, de exteriorização que a intencionalidade acarreta para a consciência. Seu grifo é reservado para a formulação "escolástica" do conceito; toda consciência é consciência de algo. $\mathrm{O}$ que Sartre pretende com tal exposição é deixar claro que, uma vez intencional, a consciência não pode existir isoladamente de seu objeto; não existe consciência pura. Mais do que simplesmente relacionada com as coisas, a consciência intencional, na leitura sartreana, só existe nessa relação com as coisas.

A implicação dessa existência relativa, vetorial, da consciência é que ela não acolhe mais os objetos em seu interior, transformando-os em representações, ela não é mais o receptáculo das idealidades e, muito menos, a criadora de um mundo ilusório. Ao contrário, é a consciência que se transcende indo na direção dos objetos. Consequentemente, os seres do mundo ganham uma autonomia metafísica em relação à consciência. Certamente, enquanto objetos, as coisas são relativas à consciência, no entanto sua realidade concreta é completamente independente do sujeito cognoscente, pois, o fato de termos consciência-de-algo já pressupõe a existência desse algo. Sartre usa o exemplo de uma árvore: aquela árvore adiante não pode ser reduzida a um conjunto de sensações, de conteúdos de consciência, pois no momento em que a vejo, minha 
consciência já a intenciona como objeto distinto de mim, exterior, uma coisa real cuja concretude incide do fato dela ser aquela árvore-lá, "na beira da estrada, no meio da poeira, só e contorcida sob o calor, a vinte milhas da costa mediterrânea." ${ }^{13} \mathrm{O}$ objeto árvore não é mais uma representação, uma idealidade "árvore”, ele é aquela árvore; um absoluto cuja existência independente e particular se impõe à consciência intencionante.

O tom realista dessa tese é evidente. De fato, o artigo que contém essa exposição, o Intencionalidade, é claramente um momento de "afirmar a presença do mundo, tal como se dá a nós" do projeto sartreano. Logo no primeiro parágrafo desse texto, Sartre elenca a lista, já citada, dos autores representantes do idealismo que ele visa combater. "Il la mangeait des yeux" ${ }^{14}$, esta expressão chamativa que abre o texto é, para o autor, a fórmula máxima da "filosofia alimentar", em outras palavras, da epistemologia idealista. E é no intento de combater essa filosofia que Sartre desenvolve sua exposição da intencionalidade. Ou seja, desde aqui, o interesse pela fidelidade fenomenológica é lateral quando comparado com o projeto realista.

O problema com o idealismo já foi mencionado; constituir uma tese na qual o mundo é reduzido a um mero conjunto de sensações, de conteúdos de consciência. Submetendo o ser ao conhecer, o idealismo não apenas relativiza, mas enclausura o mundo na interioridade subjetiva. É por isso que, ao expor criticamente essa teoria, Sartre usa com tanta frequência termos como assimilação, unificação, identificação, enfim, digestão do mundo pela consciência. A filosofia alimentar é aquela que afirma que o mundo é diligentemente assimilado pela consciência durante o processo epistemológico, as coisas deixam de ser propriamente coisas para se tornarem representações de coisas; idealidades constituídas e indistintas da própria consciência. Em última instância, aquela árvore que vejo deixaria seu entorno mediterrâneo para fazer parte do conjunto de minhas sensações. Dissolvida em minha consciência, a árvore contorcida se torna um conceito; um ser abstrato que é assimilado à substância de minha própria subjetividade. As consequências desse idealismo também já foram citadas; uma postura apática diante de um mundo mole e inconstante. Ao ser humano, desinteressado de tal mundo, só restaria

\footnotetext{
${ }^{13}$ SARTRE, J. P., "Une idée fondamentale de la phénoménologie de Husserl: L'intentionnalité" In Coorebyter, V. (ed). La transcendance de l'Ego et autres textes phénoménologiques. Paris, Vrin, 2003. p.88.

14 "ele a comia com os olhos" (Idem).
} 
a via da contemplação subjetiva, da introspecção estéril. Para a moral sartreana, o idealista é, nesse momento, o principal adversário.

O idealismo com seu cortejo de teorias sobre a constituição dos fenômenos ou de seu sentido, é um adversário central para o primeiro Sartre, pois coloca em dúvida o mundo ambiente da vida cotidiana ou da percepção. E não admite nenhuma realidade senão aquela atestada, constituída, revista e corrigida pelo espírito (COOREBYTER, 2003, p. 18).

É no contexto do combate a esse idealismo que a fenomenologia surge oferecendo a intencionalidade como uma alternativa teórica. Pois, para Sartre, essa noção anula um conceito que dava sustentação ao idealismo, que era o próprio conceito de representação. Por sua vez, a ideia de representação é o cerne da concepção espacial da consciência, pois sendo as coisas transformadas em interioridades subjetivas, é como se elas viessem "habitar" o interior da consciência. É uma relação entre continente e conteúdo a que temos aqui. Assim, aquela árvore do mundo, envolta na poeira, é duplicada quando ganha uma cópia na representação. O sujeito cognoscente só teria acesso a este clone de idealidade, um ente abstrato e plasmático, separado da árvore real, e interior à consciência. Vemos que a representação parte de um pressuposto dualista, no qual há a oposição entre a consciência e o objeto. É neste ponto que a filosofia de Husserl atua em favor do projeto sartreano. Pois, a partir da fenomenologia, seria um equívoco pensar separadamente a consciência pura de um lado, o mundo do outro, e a representação surgindo como o resultado do encontro entre esses dois elementos. Como já foi exposto, a consciência, quando existe, já é de antemão consciência de mundo e o mundo é objeto para a consciência. Ou seja, a fórmula escolástica da intencionalidade, que é o que Sartre adota, estabelece uma relação direta entre a consciência e o mundo, sem a necessidade do conceito de representação. Sartre entende que, negando o dualismo, a fenomenologia também é capaz de negar a base de sustentação do idealismo.

Uma nova descrição da consciência, livre de dualismos, começa a se esboçar com o conceito de intencionalidade. $\mathrm{O}$ artigo da Intencionalidade é o momento da obra de Sartre no qual essa descrição ganha sua forma mais realista. Como foi dito acima, o autor expõe a consciência intencional a partir de figuras imagéticas como uma explosão ou um escorregar para fora de si. São imagens da consciência sempre na forma desse movimento transcendente na direção das coisas. Neste ponto, cabe a pergunta: o que sobra da consciência por trás desse movimento de exteriorização? Nada. Sartre afirma que ela é sempre o exterior de si mesma. Uma fuga constante de si. Se transcendendo nas coisas, a 
consciência é sempre aquilo que ela não é, e não é aquilo que é. Essa ausência de estabilidade de ser da consciência, que o existencialismo irá chamar de para-si, já começa a ser delineada desde este texto primordial sartreano. Por isso, o autor afirma que a figura física mais própria para se imaginar a consciência é aquela de uma explosão. Se tentássemos entrar em uma consciência, não encontraríamos algo como um quarto fechado, completamente mobiliado pelas representações, tal como na concepção idealista. Ao contrário, seríamos imediatamente arrebatados para fora num turbilhão, lançados ao pé das coisas, cuja realidade concreta é restituída pelo conceito de intencionalidade. Trata-se de um perpétuo movimento de sair de si intencionando os objetos, movimento que não permite sequer a permanência de nenhum si. Sem qualidades, sem predicados, a consciência intencional sartreana é mais uma atividade do que propriamente um ser. Em total oposição à interioridade estática do idealismo, ela é o que eu tomo a liberdade de chamar de função centrífuga. Ou seja, um movimento constante que produz uma força de exteriorização e não permite que nada reste em seu interior. Essa é a extensão da leitura realizada por Sartre. No intuito de combater o idealismo, o autor francês ressalta o aspecto exteriorizante do conceito de Husserl, ao ponto de criar uma imagem da consciência que situa tudo fora de si, os objetos, as coisas, as qualidades, mesmo as emoções, nada disso escapa da força centrífuga exercida pela intencionalidade. Tal força expulsa o mundo e todo o seu sentido para fora do sujeito, realizando, assim, um processo de limpeza, de purificação da consciência que restará vazia. “O ser próprio da consciência não é nada que seja objetivável” (MOUILLIE, 2000, p. 23). Por fim, o próprio sujeito se vê lançado para fora de si, ao pé da árvore, em meio ao pó, num mundo preenchido de qualidade e sentido.

A concepção fenomenológica da intencionalidade da consciência é, para Sartre, a grande descoberta de Husserl. Por ela entendemos que a consciência não é uma coisa ou uma forma, um receptáculo de conteúdos ou um sistema lógico de captação de realidades, mas um simples movimento na direção das coisas. Intencionalidade significa, para Sartre, que a consciência é um fora, que ser consciente significa ir em direção às coisas e que apreendêlas não equivale a prendê-las na substancialidade do ego metafísico ou encerrálas nas possibilidades do Eu sistêmico e transcendental. (SILVA, 2014. p.22). 


\subsubsection{Demasiado realista?}

Quando vier a Primavera, Se eu já estiver morto, As flores florirão da mesma maneira. E as árvores não serão menos verdes que na Primavera passada. A realidade não precisa de mim. (Alberto Caeiro)

De Husserl a Sartre, o conceito que era uma característica eidética da consciência passa a tomar as formas de um imperativo ontológico. Para o último autor, a consciência só existe num movimento de transcendência, não possui nada em seu interior, não possui sequer um interior. Ela não tem qualidades, tudo está fora; o ser está no mundo. Destas implicações sartreanas do conceito de intencionalidade, pode-se tirar uma conclusão, a diferença entre este autor e o antigo mestre é menos de interpretação do que de projeto. O Husserl de Ideias I. almeja expor o projeto de uma fenomenologia pura, ou seja, um estudo descritivo e detalhado do campo transcendental, atendo-se apenas aos desenvolvimentos inerentes a essa esfera. Em outras palavras, esse autor via sua filosofia como o projeto de uma epistemologia pura que não esperava pelos desdobramentos existenciais de um Heidegger e, posteriormente, do próprio Sartre. Quanto a este último, como já foi dito, realizou uma recepção um tanto tendenciosa da fenomenologia. Relembro que, para ele, a grande revelação da intencionalidade era que com ela era possível filosofar sobre um coquetel de abricot. Ou seja: “O interesse de Sartre pela fenomenologia é, desde o início, existencial-ontológico. Ele quer captar os 'existentes' em sua facticidade..." (MÉSZÁROS, 2012, p. 101). A razão desse interesse é aquela que também já foi citada, a aversão de Sartre à postura contemplativa do idealismo, ou, se podemos assim chamar, a "ética realista" de Sartre.

Temos dois autores, dois projetos, mas apenas um conceito de intencionalidade. É verdade que mais restrito e técnico em um, e mais imagético e "econômico" no outro. Ainda assim, se pensarmos em termos da inspiração original, é basicamente o mesmo conceito. Desde Husserl, por princípio a consciência não tende a voltar-se para si e sim para o mundo (basta ver sua exposição sobre a atitude natural e a atitude filosófica ${ }^{15}$ ), também é desse autor a asserção de que o vivido intencional é transcendência da consciência rumo ao objeto. A diferença maior está nas consequências do uso do conceito, e não na sua acepção original. Sartre, seguindo os passos de Heidegger, implica consequências existenciais da filosofia husserliana. Tais consequências são a proposta de

\footnotetext{
${ }^{15}$ HUSSERL, E. Ideias para uma fenomenologia pura e para uma filosofia fenomenológica. Aparecida:
} Ideias \& Letras, 2006. 
uma ontologia realista. Mas, por mais que essas consequências não estivessem pressupostas no projeto husserliano, não se pode negar que suas bases sejam inspiradas por ele. É por isso que se pode dizer que “...com efeito, nada é mais husserliano do que tomar o princípio de intencionalidade como o adversário por excelência das doutrinas da interioridade." (COOREBYTER, 2000, p.58).

Mas é preciso medir a extensão fenomenológica do mundo realista constituído no artigo da Intencionalidade. Se a tese sartreana se inspira em Husserl quando estabelece um mundo onde o ser não está submetido às condições do conhecer, em outros pontos vai muito além do que se poderia implicar da metodologia fenomenológica. É um mundo alargado, pois além de restituir a objetividade da percepção, ele também apresenta o ser das coisas como algo além do olhar. Isso é resultado da exteriorização absoluta defendida por Sartre nesse artigo. Quando os sentimentos, a afetividade e todo o sentido são visados como transcendências, então aquela máscara japonesa ${ }^{16}$ é terrível porque a forma esculpida na madeira porta em si mesma essa qualidade e não porque meu temperamento assim a apreende. De fato, nesse artigo Sartre ensaia um novo tratado das paixões no qual os sentimentos subjetivos estão todos exteriorizados, manifestando-se enquanto qualidades objetivas do mundo. Nesse ponto, ele se afasta muito de Husserl, pois descreve, com a metodologia da redução fenomenológica (que em Husserl se limita ao domínio transcendental), eventos da atitude individual na orientação natural. Por fim, o papel da consciência nesse mundo absolutamente realista também deve pouco a Husserl. Pois, enquanto o autor alemão não reconhecia a intencionalidade dos sentimentos de maneira imediata, afirmando que a afetividade restaria como uma mescla de ação subjetiva e caso especial de visada intencional ${ }^{17}$, Sartre, por sua vez, carrega o polo visado com todo o valor, assim o sentimento subjetivo seria o efeito da qualidade das próprias $\operatorname{coisas}^{18}$. Desse modo, a consciência como formulada em $I$. atua quase como um mero olhar objetivo e passivo, ignorando todos os processos de constituição do sentido da fenomenologia husserliana. Além disso, para um texto que pretende apresentar a filosofia de Husserl, é surpreendente o silêncio em relação aos temas da hylé, do noema e da noese.

\footnotetext{
${ }^{16}$ Sartre usa esse exemplo no artigo da Intencionalidade. Creio que se trata das máscaras que representam assustadoras entidades sobrenaturais no tradicional teatro japonês Nô, ou talvez uma representação do folclórico Tengu. Seja como for, essas máscaras sempre apresentam feições aterrorizantes com olhos esbugalhados e dentes pontiagudos à mostra.

${ }^{17}$ Assim a intencionalidade afetiva deveria ser fundada na intencionalidade objetivante.

${ }^{18}$ Esse estudo sobre as emoções será aprofundado e, em certa medida, reformulado no Esboço para uma teoria das emoções, conforme irei expor no capítulo 4 desta dissertação.
} 
Isso acontece porque uma matéria passiva como a hylé, e um ato interno como a noese, são ideias demasiadamente próximas daquilo que Sartre entende por conteúdos de consciência, o foco principal das críticas desse mesmo artigo. Em obras como T.E. e $A$ Imaginação, o autor tentará trabalhar com esses conceitos de maneira muito embaraçosa para as demandas de seu realismo. Essas tentativas de conciliação serão abandonadas definitivamente em $O$ Ser e o Nada, quando até a noção de noema passa a sofrer acusações de flerte idealista.

Uma leitura atenta pode notar que tais críticas ao noema já estão latentes em $I$., pois quando Sartre afirma que aquela árvore que vejo é indissociável de seu entorno mediterrâneo, além de restituir o horizonte mundano, ele está associando sua realidade à sua singularidade. Esta árvore-aqui, este ser singular, ao mesmo tempo em que não pode ser assimilado pela consciência, também não pode ser reduzido a um núcleo de sentido, a uma abstração conceitual como o noema. Diferentemente do núcleo de sentido "árvore" de Husserl, a árvore-aqui de Sartre, queima. Portanto, nesse artigo, apesar de todos os elogios ao pai da fenomenologia, Sartre já se afasta de Husserl em todos os pontos nos quais suas conclusões ignoram os diversos processos subjetivos da fenomenologia husserliana. $\mathrm{O}$ autor francês recebe a inspiração original da intencionalidade, mas filtra $\mathrm{o}$ conceito, absorve apenas aquilo que lhe é útil e ignora as características que não se encaixam em seu projeto realista.

Sartre mantém de Husserl apenas aquilo que permite acabar com as filosofias alimentares: uma definição da intencionalidade como consciência de...segundo a qual a consciência é "fuga" e "deslize", como se o mundo já estivesse sempre organizado, oferecendo-se a um olhar que nele viria colher a significação, inclinando-se em sua direção. (COOREBYTER, 2003, p. 22)

Esse realismo exacerbado é surpreendente para um autor que, logo no segundo parágrafo de $I$., ao citar Bergson, lembra que "Husserl não é tão realista". Sartre não se esquece da ressalva de que aquela árvore sobre a terra ressecada não é um absoluto que entraria, posteriormente, em comunicação $\operatorname{conosco}^{19}$. Pois se o princípio de intencionalidade afirma que a consciência se implica do mundo no qual se situa (é consciência de), ele também afirma que o mundo, enquanto objeto, é relativo à consciência (pois é objeto para uma consciência). Essa é a ressalva que sua afirmação "a

\footnotetext{
${ }^{19}$ SARTRE, J. P., "Une idée fondamentale de la phénoménologie de Husserl: L'intentionnalité" In Coorebyter, V. (ed). La transcendance de l'Ego et autres textes phénoménologiques. Paris, Vrin, 2003. p.88.
} 
consciência e o mundo são dados de uma só vez"20 quer fazer. Além disso, no mesmo texto, o autor afirma que a representação é o erro comum tanto de idealistas quanto de realistas. Isso significa que além do combate ao idealismo, Sartre pretende aniquilar a sustentação de toda tese dualista, ou seja, toda tese que pressuponha uma cisão radical entre a consciência e o mundo. Pois a intencionalidade, mais do que apenas expulsar os conteúdos de consciência, faz com que mundo e consciência se coatualizem.

Parece ambíguo que num mesmo texto coabitem um realismo tão radical e a relatividade mútua entre a consciência e o mundo. O que se pode conjecturar é que quando Sartre defende "o mundo tal como se dá a nós", ele ainda não se esquece de assegurar "a soberania da consciência". Ou seja, quando Sartre carrega os objetos com todas as qualidades afetivas, conferindo ao mundo uma espessura humana, ele pretende tomar o cuidado de não submeter a consciência a uma causalidade passiva frente a esse mundo encantado, mesmo que o tom do texto seja tão enfático quanto ao ser da objetividade. $\mathrm{O}$ que ocorre nesse artigo é mais uma tentativa de exorcizar o fantasma da interioridade, livrando o ser humano da contemplação subjetiva e voltando sua atenção para seu contexto mundano. Mas, isso sem materializar completamente a realidade. Por enquanto, a pretensão ontológica de Sartre não é tão definida. O que impera, aqui, é mais sua ambição ética. No fim, Sartre não constitui uma realidade tão carregada de sentimentos, apenas traz para o âmbito da atitude do senso comum a semântica do termo fenomenologia; as qualidades das coisas são a maneira pela qual elas aparecem para a consciência, e não o resultado de processos ocorridos nas profundezas do espírito. De fato, esse texto que sintetiza a recepção sartreana do conceito de intencionalidade estabelece as bases de um projeto que será elaborado mais cuidadosamente nas obras subsequentes. No Esboço para uma teoria das emoções, por exemplo, Sartre volta sua atenção para a dinâmica da consciência na emoção, mostrando como o que em $I$. parecia ser apenas uma qualidade própria das coisas é, na verdade, um encantamento do mundo realizado pela própria consciência. Assim a qualidade continua no mundo, mas o papel constituinte da consciência é restituído pelo autor ${ }^{21}$. Mesmo no opúsculo $A$ Transcendência do Ego, cuja redação é praticamente simultânea a de I., o autor elabora mais detalhadamente a vida afetiva quando descreve o ser psíquico que é separado da consciência transcendental, mas ainda constituído por esta.

\footnotetext{
${ }^{20}$ Idem nota 19.

${ }^{21}$ Ver capítulo 4 desta dissertação.
} 
Portanto, podemos definir com mais cuidado o que seria esse realismo escolástico sartreano. Certamente não se trata de uma teoria ontológica acabada, nem mesmo algo perto de uma teoria desenvolvida. Na verdade, o próprio Sartre não afirma, em nenhum momento, estar fazendo um tal trabalho. Então, essa confirmação da existência das coisas, tal como se entregam a nós, é, acima de tudo, um chamado para uma mudança de orientação filosófica. Trata-se, sobretudo, de um apelo ético para que as preocupações filosóficas se concentrem na realidade mundana e saiam da contemplação subjetiva. $\mathrm{O}$ que eu chamo de realismo sartreano é menos uma teoria sobre o ser e mais um chamado de atenção, uma exortação para que a filosofia saia da torre de marfim e encontre no burburinho das mesas de bar, com seus coquetéis de abricot, o verdadeiro campo para suas investigações. Em outras palavras, a fenomenologia, com o conceito de intencionalidade, seria um novo método para o exame da cera de Descartes; ela não seria mais uma substância a ser subtraída dos enganosos dados sensíveis, seria sim algo a ser analisado a partir de cada uma de suas manifestações que apresentariam um aspecto parcial, porém absoluto de sua realidade. Neste primeiro momento, o realismo que Sartre encontra na fenomenologia é uma tomada de posição frente ao idealismo da filosofia universitária francesa, representada por Brunschvicg e Meyerson.

Essa leitura sartreana do conceito de intencionalidade vai continuar repercutindo ao longo de suas outras obras sobre fenomenologia. Sempre pautadas por seus anseios éticos, tais obras irão se afastar paulatinamente da influência de Husserl. A tese do vazio da consciência frente ao ser do mundo continuará sendo a mais cara para o autor francês. Nessas obras ulteriores à $I$., ele se dedicará a embasar cada vez mais essa tese, dando mais corpo ao realismo do mundo e à não naturalização da consciência. Seguindo as demandas desse projeto, a fenomenologia husserliana começará a oferecer entraves intransponíveis para a filosofia de Sartre que, por fim, terá o contorno mais claro de uma verdadeira ontologia. Pois, como pretendo ter mostrado, enquanto que para Husserl a intencionalidade é uma ação da consciência sobre seus próprios vividos, para Sartre ela é mais uma relação com o mundo. As páginas seguintes acompanharão tais desdobramentos, sempre atentas ao conceito protagonista de todo esse processo; a consciência intencional. 


\section{Renovação do sujeito: por uma consciência anônima}

\subsection{Um campo transcendental impessoal}

Meu coração é um balde despejado. Como os que invocam espíritos invocam espíritos. Invoco. A mim mesmo e não encontro nada (Álvaro de Campos, Tabacaria)

\section{1. 1. Translucidez}

Como foi exposto no capítulo anterior, a consciência intencional tem uma relação direta com o mundo. Esse vis-à-vis da consciência com seus objetos não comporta nenhuma mediação. No artigo sobre a Intencionalidade, inscrito no terreno da epistemologia, Sartre se dedica a mostrar que o conceito de representação, uma vez excluído das preocupações filosóficas, não pode mais atuar nesse papel de mediador entre a consciência e o mundo. Mas, nas obras subsequentes, a descrição sartreana do vazio da subjetividade vai mais além. Expondo a vida da consciência a partir dessa simplicidade na qual ser e aparecer são o mesmo, Sartre vai apresentar uma definição segundo a qual nada vai mediar nenhuma relação da consciência com seus objetos. Nessa tese, a aparição é o absoluto, nenhuma lâmina de opacidade pode ser colocada entre o "olhar" da consciência e a presença do ser que lhe está adiante. Assim como a representação é excluída no campo epistemológico, também na vida psicológica, nenhuma determinação anterior, nenhum condicionamento estrutural, irão se interpor entre a consciência e seu vivido. Translucidez é o termo usado por Sartre para descrever essa propriedade da consciência de ser estritamente a sua própria aparição, de não possuir complexos ou conceitos mediadores que obscureçam a realidade que se faz presente num instante imediato. Essa é a propriedade que o autor vai chamar de "transparência a si" em $O$ Ser e $o$ Nada. Em outras palavras, afirmar que a consciência é translúcida, significa dizer que existir e ter consciência da própria existência são o mesmo para a consciência intencional, ela é perfeitamente clara e transparente para si, nada se esconde nela.

O translúcido autoriza a intencionalidade e vice-versa: desprovida de intimidade, a consciência não é autocentrada, não se interpõe entre si e seu correlato noemático, não vem a tropeçar sobre si mesma durante o movimento no qual ela se tende rumo a tal correlato (...). Da mesma forma que a luz não pode iluminar a luz, a consciência translúcida não pode apreender a si própria 
enquanto tal, pois ela não teria nada a apreender. (COOREBYTER, 2000, p.259)

Essa característica translúcida ocorre porque a consciência não se limita a ser consciência apenas do objeto, simultaneamente à apreensão objetiva ela é também consciência de ser consciência de objeto. Ou seja, ter consciência de algo é o mesmo que ter consciência de ser consciência de algo. O movimento parece vertiginoso, mas é essa propriedade que define propriamente uma consciência. Sem tal propriedade, a consciência poderia se perder em sua abertura para o mundo, sendo uma mera estrutura universal de desvelamento fenomênico, quase que um olhar onisciente e passivo que se confundiria com o próprio objeto, tal como uma leitura desatenta de $I$. poderia indicar. Mas, a consciência não é o objeto justamente por ser consciência do objeto. Essa é a mesma distinção entre a passividade do ser em-si e a espontaneidade do para-si das obras dos anos $40^{22}$. Ou ainda, é a mesma distinção entre o peso pegajoso da pedra e o melancólico Antoine de Roquentin que a segura na beira do lago em A Náusea. Isso ocorre, pois ser consciência significa exatamente ser este ser-ciente. Aqui não se trata de um conhecimento ou compreensão, mas apenas da autoconsciência imediata que a consciência tem de si, ainda num plano completamente irrefletido. Para dar conta desta imagem da consciência como autoconsciência que é anterior a qualquer reflexão ou conhecimento, Sartre passará, a partir de $\mathrm{O}$ Ser e o Nada, a empregar parênteses no termo conscience (de) $s o i^{23}$. Para o autor, esse recurso permite expressar a relação não objetivante e não cognitiva que a consciência tem consigo mesma em sua forma mais imediata. Mas essa ideia já estava presente nas obras anteriores que são o objeto desta pesquisa, apenas a sofisticação de sintaxe ainda não havia sido empregada. O que importa por enquanto é que, sendo consciência de ser consciência, a consciência se torna perfeitamente clara para si. Ela se entrega a si completamente de ponta a ponta. Essa é sua diferença fundamental em relação à opacidade dos objetos; um conteúdo opaco deve ser desdobrado, lentamente desvelado e apreendido por sucessivos perfis, já a

\footnotetext{
${ }^{22}$ Não obstante os termos em-si e para para-si só serem profundamente trabalhados a partir de $O$ ser e $O$ Nada, Sartre já faz um breve uso deles em A Imaginação. Desde a década de 30 eles já são utilizados fundamentalmente para distinguir o modo de existência passivo e denso do mundo material, em oposição à existência ativa e auto reflexiva da consciência. No capítulo 3 desta dissertação haverá uma subseção para apresentá-los no seu contexto nas obras de psicologia fenomenológica, no quarto capítulo retomarei esses conceitos para expor algumas das conclusões desta pesquisa.

${ }^{23}$ Consciência (de) si.
} 
consciência, porque translúcida, se entrega de uma vez, ela é exatamente sua própria aparição, não possui conteúdos a serem desvendados.

Significa que o tipo de existência da consciência é ser consciência de si. E ela toma consciência de si na medida em que é consciência de um objeto transcendente. Tudo é, então, claro e lúcido na consciência: o objeto está em face dela com sua opacidade característica, mas ela é pura e simplesmente consciência de ser consciência desse objeto, esta é a lei de sua existência. (SARTRE, 2003b, p.98)

A translucidez acarreta diversas consequências para a teoria do sujeito, pois, em primeiro lugar, pode-se notar que é a apreensão de outrem que possibilita a apreensão de si (o que vai de total acordo com a ética que Sartre quer estabelecer). Além disso, já é possível antever que noções como Ego e inconsciente não têm lugar nesse plano imediato da consciência. A própria noção de sujeito será, no mínimo, renovada a partir da tese sartreana. Pretendo desenvolver essas questões acerca da subjetividade nas próximas páginas. Por enquanto, gostaria de chamar atenção para uma consequência do translúcido na concepção ontológica da consciência. $\mathrm{O}$ vocabulário sartreano nunca é gratuito. Os termos de leveza, vazio, transparência, translucidez, são imagens etéreas da consciência sempre usadas para se contraporem às imagens de conteúdos, estados, impressões, interior, ou seja, vocábulos demasiado pesados devido a sua conotação naturalista. A definição de translucidez da consciência faz parte do momento de "afirmar a soberania da consciência" da obra sartreana. Nesse momento, tal afirmação se faz a partir da constituição de uma ideia da consciência que se afaste de qualquer imagem material. A ontologia do mundo material é densa e pesada, isso se traduz na rígida submissão de seus entes às leis mecânicas da física. Toda substância extensa está submetida à causalidade. Mas, de sua parte, a consciência não compartilha dos atributos materiais e é por essa razão que ela não está, também, submetida à causalidade natural. Sendo assim, Sartre acredita que estabelecer a distinção de natureza entre o modo de ser da consciência e o modo de ser das coisas, significa garantir a autonomia da consciência frente ao determinismo do mundo material. Translucidez, que é a síntese de todas as características descritas em $I$., implica na não substancialização, que por sua vez implica na característica não natural da consciência. Por essa razão, Sartre estabelece a translucidez como a característica mais fundamental desse ente. 
A translucidez da consciência exprime essa impossibilidade de uma carência face a face de seu próprio ser: uma consciência não pode carecer de consciência. O mesmo é dizer que a determinação eidética da consciência conduz à crítica da concepção coisicista de inconsciente. (MOUILLIE, 2000, p. 36)

A possibilidade da existência de algum conteúdo no interior da consciência ameaçaria submetê-la à causalidade natural. Sendo assim, a negação do Ego, enquanto habitante da consciência, é parte fundamental do projeto sartreano, pois possibilita garantir a soberania da consciência. Em resumo, não substancialização é o mesmo que não coisificação da consciência, portanto assegurar sua característica translúcida significa garantir sua autonomia, é esse o projeto que anima o embate com o Eu no ensaio sobre $A$ Transcendência do Ego, conforme abordarei nas próximas páginas.

\subsubsection{Um cogito pre-reflexivo; diálogos com Descartes e Kant}

A descrição da consciência (de) si - esta propriedade de saber-se consciência, anterior a qualquer relação cognitiva - é a descrição mais imediata e pura do campo transcendental. Disso decorre um nível da apreensão fenomênica que é anterior a qualquer estrutura material ou formal que se interponha entre a consciência nua e o objeto. O que Sartre propõe com a apresentação dessa translucidez da auto-ciência é a demarcação de uma camada primordial da consciência que seria anterior a qualquer uma já apresentada pelas teorias tradicionais do sujeito. Trata-se de um novo cogito, que irá mais afundo na fórmula cartesiana do Eu penso, e encontrará um nível anterior a essa formulação por demais sobrecarregada com a estrutura egológica. O que Sartre busca é de um cogito prereflexivo.

O objetivo de Sartre, ao apresentar seu cogito pre-reflexivo, não é outro senão exorcizar a presença de qualquer estrutura egológica na consciência. Seja o Ego psíquico, seja o Eu puro husserliano, ou o Eu transcendental kantiano, toda forma de Eu e, portanto, de pessoalidade acarreta em opacidade para a consciência, o que põe em risco os resultados obtidos pelo conceito de intencionalidade. Portanto, tal crítica à pessoalidade é apenas uma implicação da fenomenologia defendida por Sartre, que já estava implícita na conclusão de $I$., texto que não cansa de anunciar o vazio absoluto da consciência. $O$ Ego, em todas as suas manifestações, é para Sartre mais um conteúdo que deve ser 
expulso do domínio transcendental, da mesma forma que as sensações e paixões o foram em $I$. Além disso, o Ego confere naturalização para a consciência, uma vez que funciona como um conteúdo, indo contra o princípio de translucidez. Por isso, o autor deve atestar a ausência do Ego no interior da consciência e, segundo suas próprias palavras ${ }^{24}$, o ponto de partida para tal empreitada intelectual deve ser um estudo do cogito.

No ensaio sobre a Transcendência do Ego, a necessidade de se reexaminar o cogito surge quando Sartre investiga a presença do Eu formal no interior da consciência. Essa investigação começa a partir de uma consideração da filosofia transcendental kantiana, pois é aqui que se determinam as condições de possibilidade da experiência e, portanto, a natureza do campo transcendental. Logo após o parágrafo introdutório, a primeira frase do opúsculo é a seguinte: "É preciso concordar com Kant que 'o Eu Penso deve poder acompanhar todas nossas representações"'25. O propósito de Sartre é questionar, para depois negar, a presença de fato deste $\mathrm{Eu}$ em cada uma de nossas representações. A referência inicial a Kant não é por acaso. Ele, e não Husserl, é o primeiro a abordar o tema da unificação dos fluxos de consciência. Em $I$. essa questão ficara em aberto, Sartre nada comenta sobre a ligação entre cada uma das explosões da consciência rumo ao mundo. Porém, agora, é este mesmo tema que arrisca inserir o Eu no interior da consciência, confundindo-se a unidade do fluxo de vividos com uma unidade identitária. Pois, um dos argumentos em defesa da existência de um Eu puro é que ele seria uma estrutura lógica de unificação da consciência, sendo o centro referencial desse fluxo de vividos. Deste modo, voltar a Kant significa se remeter à origem da questão. Há que se perguntar, haveria um Eu que acompanha de fato as representações, cumprindo o papel de unificar os vividos de modo que eles se remetam a uma mesma consciência, sendo assim uma condição da apreensão fenomênica, um ente interior, ou mesmo, anterior à consciência pura de I.? Em outras palavras, existe um Eu transcendental que condiciona a experiência e, portanto, se interpõe entre a consciência e o mundo, conferindo um componente irreversível de opacidade nessa relação?

Para escapar do perigo de uma resposta positiva, Sartre chama atenção para um detalhe simples. Sem ir contra Kant, o autor francês apenas afirma que os questionamentos acerca da efetividade do Eu são formulações alheias ao pensamento do

\footnotetext{
24 “No ' $E u$ penso' há um $E u$ que pensa. Nós atingimos, aqui, o Eu na sua pureza e é exatamente do Cogito que uma 'Egologia' deve partir.” (SARTRE,2003b, p.99)

${ }^{25}$ Idem, p. 95.
} 
filósofo de Konigsberg ${ }^{26}$. Uma afirmação sobre a existência factual força demais o que se poderia depreender da fórmula "deve poder", feita logo acima ${ }^{27}$. Portanto, tal investigação estaria extrapolando os limites críticos da filosofia kantiana. Saindo do terreno crítico, que apenas investiga as condições de possibilidade e como é a experiência, os filósofos que afirmam a existência factual do Eu estão adentrando num terreno existencial, que investiga o que é que condiciona a experiência. Portanto, tentar realizar de fato um suposto Eu transcendental kantiano, que é apenas uma condição de direito, seria uma extrapolação metodológica que poderia deturpar a filosofia crítica, conferindolhe caracteres metafísicos. Sartre atribui essa tentativa aos neo-kantianos franceses, e afirma que tais autores, no lugar de serem fieis à filosofia kantiana, na verdade se afastam dela quando tentam realizar as condições de possibilidade determinadas pela crítica; são menos críticos e mais metafísicos. Para combater essa tendência, o auto francês pretende ater-se rigorosamente à ortodoxia crítica de Kant. Para isso, ele faz acento nas pretensões unicamente delimitativas de uma filosofia que apenas investiga questões de direito. O Eu penso deve poder acompanhar cada uma de nossas representações? Sim, deve. Mas isso apenas significa que "eu posso sempre considerar minha percepção ou meu pensamento como meus: eis tudo" (SARTRE, 2003b, p.94). O que se tem aqui é apenas a determinação de uma das condições de possibilidade da experiência, mas, segundo Sartre, isso não significaria para Kant uma afirmação sobre a existência factual de uma entidade como o Eu transcendental. Para o autor francês, as questões de fato passam ao largo do criticismo.

Mas Sartre não nega a importância da questão de fato, na verdade este é o escopo de seu artigo. É neste ponto que surge a fenomenologia de Husserl. Com sua metodologia descritiva ela é a única que pode oferecer uma via de investigação sobre o tema, pois a filosofia crítica encontra seu limite no momento em que se interroga não sobre como a experiência é condicionada, mas sobre $o$ que é que a condiciona.

A questão posta pelo kantismo não pode ser resolvida sobre seu próprio terreno, pois sua lógica lhe impõe recusar toda experiência do transcendental para identificar o transcendental da experiência, lhe obriga a reduzir o conhecimento do a priori ao fato que ele constitui o a priori do

\footnotetext{
${ }^{26}$ Certamente, a estratégia de não debater diretamente com Kant não se deve a um excessivo respeito pelo filósofo iluminista. Essa opção de Sartre segue o objetivo de se concentrar no combate de sua verdadeira adversária; a filosofia universitária francesa representada pelo neo-kantismo.

${ }^{27}$ Que, aparentemente, Sartre encontra na Crítica da Razão Pura.
} 
conhecimento. O problema das relações entre o Eu puro e a consciência (...) não encontrará solução senão com Husserl, na medida em que a tripla redução (fenomenológica, eidética e transcendental) faz surgir uma consciência resguardada da objetividade, mas acessível ao olhar porque é concreta. (COOREBYTER, 2000. p. 181).

Se, para Kant, o "Eu penso" é apenas uma condição de possibilidade, para Descartes e Husserl é uma necessidade de fato. Ou seja, nesses últimos autores, o eu pensante não se trata apenas de um condicionador da experiência, mas é o objeto real apreendido por uma intuição. Isso significa que o cogito é uma constatação eidética da consciência e as coisas por ele descritas são existências factuais. Tomado na fórmula cartesiana, o cogito é evidentemente pessoal, pois há um "Eu" que pensa. Portanto, para validar sua posição de uma consciência vazia, Sartre precisa reavaliar o status do cogito cartesiano enquanto descrição primeira da consciência, pois o Eu nesse cogito é inegável, além de ser a forma mais pura de pessoalidade. Se a verdade necessária do cogito se aplicar à consciência imediata, então aquele ente etéreo descrito em $I$. perderá sua validade. Nesse sentido, Sartre chama a atenção para o fato de o cogito ser um procedimento reflexivo. A reflexão é um ato pelo qual a consciência toma a si mesma como objeto. Nesse procedimento, ela sai de seu estado habitual de atenção mundana e tematiza a si própria. No momento dessa tematização de si, a consciência realiza quase que uma dobra; tem-se a consciência reflexiva que realiza o ato de reflexão e uma consciência refletida que passa a ser o tema dessa reflexão. Sartre ilustra esse procedimento no caso do exame de uma memória. Posso me recordar da paisagem que vi ontem no trem. Além dos detalhes da própria paisagem (com as árvores e casas), posso considerar que $e u$ via tal paisagem. Este Eu, que surge mediante essa ou qualquer outra memória refletida, é a garantia de fato da afirmação de direito kantiana. Daí poder-se-ia concluir que o Eu é o companheiro factual de toda consciência, que basta uma simples rememoração para ele explicitar sua presença? A resposta de Sartre é negativa.

Sartre atenta para o fato de que a reflexão é uma consciência de segundo grau. $\mathrm{Ou}$ seja, além de não ser o estado habitual da consciência, o momento reflexivo é uma variação da consciência primária, que é a irrefletida, aquela que está totalmente absorvida no mundo transcendente. Aqui, cabe mostrar a distinção dessa consciência de segundo grau que é a consciência reflexiva, e a consciência (de) si descrita acima quando tematizei a translucidez. Ambos os casos são "consciências de consciência", é verdade. Porém, no caso da consciência (de) si que decorre da translucidez, tem-se uma consciência não 
tética. Ou seja, é uma consciência que não se tematiza, não toma a si mesma como objeto, ela apenas sabe-se a si mesma como consciência. Já a reflexão é uma tomada de posição consciente (no sentido de que se realiza a partir de uma decisão). A reflexão torna a consciência num objeto, procedimento que de maneira alguma ocorre com a consciência (de) si. Portanto, temos aqui diversos níveis diferentes de consciência. Em primeiro lugar a consciência irrefletida e espontânea, que é ciente de ser consciência, mas que tem como único tema seu objeto transcendente (a paisagem do trem, por exemplo). Ela sempre está completamente absorvida no mundo ambiente, é espontânea e não depende de nenhuma outra consciência para existir. Em segundo lugar, há a consciência reflexiva, ela é uma consciência de segundo grau e toma, de modo posicional, a própria consciência como objeto (os meus pensamentos no momento em que via a paisagem do trem). O que ela tematiza não é seu ato reflexivo, mas sim a consciência irrefletida que lhe é anterior e de que necessita para existir. Portanto, em si mesma, a consciência reflexiva também é irrefletida $^{28}$. Por fim, temos a consciência refletida, objeto da reflexão e que, a partir desse ato, sofre uma alteração na sua estrutura.

A alteração sofrida pela consciência irrefletida, quando submetida à reflexão e tornada refletida, é justamente a aparição do $\mathrm{Eu}$. Por exemplo, quando me lembro de minha leitura de ontem, posso afirmar "Eu lia tal livro". E toda vez em que reflito sobre uma vivência passada, esse Eu aparece como que por detrás da consciência refletida ${ }^{29}$. Mais uma vez, eis a garantia de fato da afirmação de direito kantiana. Mas, uma vez que antes da reflexão não há consciência posicional, a questão que se coloca é: o ato reflexivo encontra um Eu que sempre esteve lá, mas se manteve escondido, ou, na verdade, cria esse Eu na consciência refletida? Para Sartre, o método para descobrir isso é consultando uma consciência irrefletida, que ainda não tenha sofrido as modificações causadas pelo ato reflexivo. Isso é possível, pois a consciência irrefletida deixa um rastro não tético de si, capaz de ser consultado na lembrança. Os limites empíricos da memória não invalidam seus direitos eidéticos, suas possibilidades de princípio. Isto é, embora a memória

\footnotetext{
${ }^{28}$ Para tematizar o ato reflexivo seria necessário um ato de terceiro grau, o que não implica em um recuo ao infinito como Sartre mostra em: SARTRE, J. P., “La transcendence de l'Ego: esquisse d'une description phénoménologique” In Coorebyter, V. (ed). La transcendance de l'Ego et autres textes phénoménologiques. Paris, Vrin, 2003. p. 100.

${ }^{29}$ Não é de se espantar que a transformação da consciência em objeto resulte em confusões naturalizantes. "Fazendo retorno sobre si mesma, a consciência reflexiva pode ser tentada a constituir a consciência refletida num objeto e, assim fazendo, desnaturalizar a subjetividade ao ponto de fazer dela uma realidade mundana" (CABESTAN, 2015, p. 24). Essa questão da objetivação da consciência será aprofundada no capítulo 3 desta dissertação, quando tratarei da crítica ao psicologismo.
} 
comporte sempre um fator dúbio quanto aos objetos de sua lembrança (aquela árvore na janela era uma pitangueira ou um limoeiro), as propriedades essenciais da consciência que viveu a memória nunca se alteram e se oferecem à consulta do procedimento fenomenológico (a estrutura eidética é inalterável). Consultando, assim, uma consciência irrefletida, com o cuidado de não a contaminar com as considerações da consciência reflexiva, o autor utiliza o procedimento da descrição fenomenológica para inventariar o conteúdo irrefletido. Dessa forma, a atenção é voltada não para a consciência em si, mas para os "objetos ressuscitados". O resultado encontrado por esse procedimento é a ausência do Eu. No caso da leitura, por exemplo; "enquanto eu lia, havia consciência do livro, dos heróis do romance, mas o $E u$ não habitava essa consciência, ela era apenas consciência do objeto e consciência não posicional dela mesma" (SARTRE, 2003b, p. 101). Para o autor, esse mesmo resultado se repetirá em todos os casos em que se consulte uma consciência irrefletida. Portanto, é possível concluir que o Eu não existe no plano irrefletido.

Apesar de sua ausência no plano irrefletido, o Eu sempre pode aparecer mediante a reflexão. Segundo Sartre, isso não é suficiente para crer que ele seja uma mera descoberta reflexiva, um ente que já existia na consciência irrefletida e apenas esperava o olhar reflexivo para se revelar. Isso porque, como já foi visto, a consciência irrefletida não é nada além de seus próprios vividos. É verdade que o Eu é percebido pela consciência reflexiva, mas a maneira pela qual ele aparece já denuncia sua diferença essencial em relação à consciência e seus vividos. Há uma distinção fundamental entre vivido e percebido. Diferentemente do último, o vivido se dá por inteiro, não se revela através de sucessivos perfis. Ora, a consciência reflexiva percebe o Eu como algo a ser revelado, que permanece além das vivências pontuais. Quando a consciência reflexiva captura o eu penso, ela não captura um momento real e concreto, pois ele afirma sua permanência para além de todas as apreensões. Por uma questão essencial, o Eu não pode fazer parte do campo translúcido da consciência irrefletida. Portanto, a consciência de primeiro grau não conhece nenhuma estrutura egológica, mas apenas o contato com o mundo. "De fato, sou então mergulhado no mundo dos objetos, são eles quem constituem a unidade de minhas consciências, que se apresentam com valores, qualidades atrativas e repulsivas, mas eu, eu desapareci, fui nadificado." (Idem, p. 102)

O cogito cartesiano afirma demais. A certeza do ato reflexivo só pode ser apoiada numa consciência sem facetas, que se entrega por inteira. Na medida em que o eu parece 
compartilhar muito mais os caracteres dos objetos transcendentes do que da consciência, um verdadeiro cogito não deveria dizer "Eu penso", mas apenas "Há pensamento", é isso o que um exame do nível mais primário da consciência indica. Esse é o cogito prereflexivo, o cogito que lida com a consciência irrefletida que não depende da consciência reflexiva para existir, mas ao contrário, é a possibilidade de existência desta última. $\mathrm{O}$ cogito deve se aprofundar até esse nível da consciência, pois é o seu nível mais imediato. Por fim, o cogito pre-reflexivo encontra um campo transcendental absolutamente impessoal. A consciência espontânea e irrefletida não necessita nem da reflexão e nem da pessoalidade para existir. A translucidez encontra uma forma tão leve que sequer uma identidade pode nela habitar; a atenção ao mundo nadifica o Eu.

Assim o abandono do cogito reflexivo - formação segunda - em proveito do cogito pre-reflexivo nos permite reencontrar o ser do percipiens, quer dizer, da consciência, o ser do mundo e a existência de outrem. Tal método nos protegerá, ao mesmo tempo, do idealismo - pois o ser do fenômeno é, por princípio, distinto de seu ser conhecido - e do realismo - pois a consciência é articulada no mundo em seu ser. Este método restituirá ao ' $\mathrm{Eu}$ penso' cartesiano sua riqueza concreta e sua apodicidade. (SARTRE, 2003c, p. 138)

\subsubsection{Autossuficiência: a unificação da consciência.}

Como foi dito no início da seção anterior, Sartre inicia seu ensaio sobre o Ego citando a filosofia de Kant, pois este autor foi o primeiro a abordar, de forma crítica, a unificação da consciência. A questão sobre como a consciência encontra sua coesão, a despeito da multiplicidade de suas vivências, é um dos temas centrais para a fenomenologia. Para a presente reflexão sartreana, esse tema é especialmente importante, pois o Eu formal poderia ser considerado como o unificador das consciências. Portanto, mostrar como a consciência se unifica, sem o recurso ao Eu, passa pela trajetória do programa filosófico do autor. Sartre adota a tese de que a consciência se unifica sozinha, mostrando a plena autossuficiência desse ente frente a qualquer estrutura que the seja distinta, conforme tentarei mostrar nos próximos parágrafos.

Quando Sartre explora a unificação da consciência em T.E., ele está fazendo mais do que expor a inutilidade do $\mathrm{Eu}$ formal para uma compreensão fenomenológica da consciência, ele está tendo a oportunidade de retomar um tema que restara insuficiente 
em I.; a temporalidade. Este último artigo fizera silêncio sobre o tema, e a maneira pela qual as sucessivas explosões da consciência se uniam restou um mistério. No artigo sobre o Ego, o autor vai desenvolver essa questão a partir da inspiração do Husserl das Meditações Cartesianas e das Investigações Lógicas para se contrapor àquele de Ideias $I$, pois nesta última obra o filósofo alemão "ressuscita" o Eu puro como polo de unificação dos fluxos de consciência ${ }^{30}$. Seguindo a argumentação de Sartre, uma vez que a consciência se define pela intencionalidade, sua unidade se constitui no próprio objeto de que é consciência. Afinal, já que a consciência se transcende em seu objeto, a unidade do mesmo permitirá a unidade de suas respectivas visadas intencionais ${ }^{31}$. Além disso, a consciência existe no tempo, de maneira que ela é um fluxo contínuo. Ou seja, ela não é uma sucessão de instantes, ela não se desenrola como se fosse um rolo antigo de filmes de cinema, uma sequência de imagens separadas. Ao contrário, ela é contínua como as paisagens de uma estrada num carro em movimento. Para Husserl, a consciência transcorre dessa maneira no tempo a partir de um sistema de retenções e protensões. Ou seja, as vivências passadas são retidas, permanecem nas presentes, ao passo que uma vivência atual já antevê uma futura. É desse modo que a consciência se dá em fluxo, o passado permanece no presente, ao mesmo tempo em que o presente já antecipa o futuro. O sistema retencional e protensional parece ser o que Sartre quer indicar quando cita um “jogo de intencionalidades transversais" (SARTRE, 2003b, p. 97). Ou seja, a continuidade do fluxo da consciência acontece pelo cruzamento e intercalação recíproca de seus diferentes momentos temporais, quando uns preveem e supõem os outros. É digno de nota que Sartre pouco use, em seu texto, os termos husserlianos de retenção e protensão. $\mathrm{Na}$ verdade, ele nada diz sobre a protensão ao futuro. Como ele mesmo irá admitir no Diário de uma guerra estranha, o tema da temporalidade ainda lhe era uma grande dificuldade. Por essa razão, desde $I$. ele trabalha o tema com certo embaraço. No ensaio sobre a Transcendência do Ego, essa dificuldade aparece em relação ao trato do futuro, seu jogo de intencionalidades transversais e os exemplos do texto se referem apenas às relações entre passado e presente. Essas dificuldades são inerentes à tese da

\footnotetext{
${ }^{30}$ Não cabe aqui uma análise profunda dos motivos pelos quais Husserl muda de posição entre suas obras, o próprio livro de Ideias I esclarece muitos pontos sobre esse assunto. Apenas quero destacar que a tensão conceitual no que concerne ao Eu entre os dois autores, se deve ao método de redução realizado. Diferentemente de Husserl, Sartre não possuía uma fenomenologia do tempo, conforme tratarei na próxima seção deste capítulo e, de forma mais aprofundada, no capítulo 4 desta dissertação.

31 "Assim, o objeto, enquanto transcendente, torna desnecessário o recurso ao Eu unificante. Na medida em que é verdadeiramente transcendente, ele já é aquela unidade real e, por isso mesmo, a unidade não forjada das consciências." (MOUTINHO, 1995b. p. 28).
} 
criação ex nihilo que o autor atribui à consciência nesse texto. Em linhas gerais, a temporalidade dos primeiros textos sartreanos parece estar submetida ao império do instante. As dificuldades teóricas desse tema serão superadas paulatinamente nas sucessivas obras do autor, até que, por fim, o tema da temporalidade em Sartre encontrará sua forma mais acabada apenas em O Ser e o Nada, obra pós-leitura de Heidegger. Mas, não se deve atribuir o uso das intencionalidades transversais apenas à dificuldade sartreana com o tempo, o sistema husserliano de retenções implica em sínteses passivas e, como pode-se imaginar, é acima de tudo a passividade, e não a temporalidade, que Sartre quer evitar na constituição da sua concepção de consciência. Por enquanto, esse não é o tema desta pesquisa, ele voltará a aparecer mais adiante quando serão tratadas as obras de psicologia fenomenológica na segunda parte desta dissertação. Por hora, fica apenas esta ressalva em relação à dificuldade sartreana em tratar sobre o futuro, mas o que nos interessa é que o autor francês está atento à natureza de fluxo temporal da consciência. Essa natureza faz com que, através das intencionalidades transversais, a consciência se remeta sempre a si mesma, unificando continuamente seus momentos sem a necessidade do recurso ao Eu. Através de sua temporalização, a consciência se mantém contínua por si só.

Em seguida, Sartre também afirma que o Eu é inútil para conferir individualidade à consciência. Aqui o autor argumenta que, além do fato de unidade implicar individualidade, a própria natureza imanente da consciência lhe confere sua individualidade, uma vez que ela é uma totalidade sintética fechada em si, um sistema de auto referências, sem conexão com as outras de seu tipo. $\mathrm{O}$ autor usa como analogia o conceito de Substância de Espinosa. Um sistema absoluto, uma imanência de si a si que não se intercala com outros do mesmo tipo. A consciência sartreana é uma totalidade; ela é individual porque é total. Portanto, podemos notar que tanto num caso como em outro, o recurso ao Eu não é faz necessário, a intencionalidade e o fluxo temporal conferirão por si mesmos a unidade e a individualidade da consciência.

No texto de T.E. o autor trabalha esse tema da auto unificação visando mostrar a inutilidade conceitual do Eu formal, para, em seguida, poder atestar sua ausência factual na consciência (tema tratado na seção anterior). Mas, aqui, eu pretendo sugerir que essa autossuficiência da consciência frente a qualquer estrutura egológica, seja formal ou material, indica que a consciência começa a reclamar para si características que sempre foram atribuídas ao sujeito clássico. A auto unificação indica que a consciência não é uma 
passividade observadora, regulada e centralizada por um Eu, habitada por um sujeito. Ao contrário, a consciência sartreana é uma atividade absolutamente impessoal. Mas essa impessoalidade não significa alienação frente a suas próprias dinâmicas. Significa que a consciência nunca coincide consigo mesma, não há nenhuma identidade que nela permaneça e que rege tal atividade. Mas a atividade é autoconsciente, ou melhor, é consciência (de) si. É uma espontaneidade que não pode ser determinada por nada. É quase como um sujeito sem identidade, mas que, nem por isso, perde sua autonomia de autor das suas ações. Por fim, na crítica à subjetividade realizada na filosofia sartreana, mais do que um mero abandono da noção de sujeito, o que se verá será mais uma substituição dos papeis que eram atribuídos para este último, tais papeis deixam o Eu e passam para a própria consciência. Mas pretendo desenvolver esse ponto ulteriormente ao longo deste texto. Por hora, vale apenas ressaltar esta importância do tema da auto unificação da consciência.

\section{1. 4. Questão de método em fenomenologia}

Como foi dito no capítulo anterior, no artigo sobre a Intencionalidade, Sartre realiza uma leitura seletiva da fenomenologia de Husserl. Nessa obra, o autor exacerba o aspecto exteriorizante do conceito husserliano para melhor combater o idealismo subjetivista. Em T.E. essa leitura enviesada da obra do filósofo alemão continua. Nesse texto, a apropriação peculiar incide sobre a metodologia da reflexão a ser realizada. Ainda se reivindicando do procedimento fenomenológico, as investigações nesse texto seguem um método diferente daquele de Husserl que é a reflexão fenomenológica. Na verdade, Sartre pretende trabalhar com uma versão ainda mais rigorosa desse tipo de reflexão. Como Sacrini ${ }^{32}$ aponta, além do afastamento das posições husserlianas quanto à questão do Eu puro, Sartre também diverge do filósofo alemão no que concerne ao critério de evidência da reflexão. Isso, por sua vez, acarreta numa metodologia investigativa diferente da fenomenológica, mesmo que o autor francês ainda reivindique a influência da fenomenologia no ensaio sobre o Ego. Acontece que, sempre no intuito de preservar a purificação do campo transcendental, Sartre opera suas investigações com o que ele chama de reflexão pura. Essa reflexão opera uma purificação do campo das vivências

\footnotetext{
${ }^{32}$ SACRINI, M. A. F. Sartre entre reflexão fenomenológica e reflexão pura. Goiânia: Philósophos, v.17, n.1, 2012.
} 
muito mais rígida do que a simples redução fenomenológica. Essa rigidez é um resultado do critério de evidência exigido pelo autor francês. A seguir, pretendo apresentar muito sucintamente a diferença dessa metodologia sartreana em relação ao método fenomenológico original.

Como se sabe, o projeto fenomenológico apresentado por Husserl, a partir de 1906, consiste em explorar como a consciência transcendental constitui o mundo fenomenal a partir de seus processos intencionais. $\mathrm{O}$ acesso à imanência do campo transcendental acontece através da redução fenomenológica. O procedimento é conhecido, a epoché coloca o mundo entre parênteses, ou seja, a tese da realidade das coisas fica em suspensão. Assim, é possível estudar o que sobra após a redução; o mundo enquanto correlato da consciência, as vivências puras. "Uma vez que se suspende a validade das crenças e conhecimentos acerca da existência transcendente das coisas, revela-se a pura fenomenalidade, a pura correlação entre as capacidades da consciência e os objetos enquanto manifestados para a consciência". ${ }^{33}$

Ao contrário do mundo real, o mundo como correlato de consciência, reduzido às vivências, não se perfila, mas se doa de uma só vez. Isso significa que, encerradas em si mesmas, as vivências são completas em sua aparição. Diferentemente dos objetos transcendentes, as vivências não necessitam da apreensão de infinitos pontos de vista para o conhecimento de sua totalidade. As vivências se dão por inteiras, seu ser se resume e coincide com seu aparecer. Graças a essa propriedade, elas gozam de evidência para toda reflexão que se lhes imponha. Para Husserl, esse critério de evidência, seguido rigorosamente, valeria apenas para a instantaneidade do momento presente. Mas ocorre que, como foi dito na seção anterior, a fenomenologia entende a consciência como um fluxo temporal. Nesse fluxo contínuo das vivências não é possível isolar, a não ser por abstração, um instante único. Husserl tem consciência dessa dificuldade, por essa razão, segundo Sacrini, ele flexibiliza o critério de evidência da reflexão fenomenológica. Assim, o autor alemão admite que possa haver diferentes graus de evidência daquilo que se manifesta no campo fenomenológico da consciência pura. Desse modo, a evidência adequada se limita à percepção do presente, no entanto, as evidências dos diferentes momentos temporais da consciência continuarão sendo válidas apesar de seu menor grau de adequação.

\footnotetext{
${ }^{33}$ Idem nota 32, p. 114.
} 
Aquilo que é presente, manifesta-se com evidência adequada, e esse não é o caso daquilo que é passado ou abertura protensional ao futuro. Mas mesmo se dotado de um grau menor de evidência, aquilo que é passado, por exemplo, deve ser considerado pela reflexão fenomenológica. (SACRINI, 2012, p. 116)

Para Husserl, manter a validade das evidências não inteiramente adequadas na reflexão fenomenológica significa respeitar o fluxo temporal da consciência. Por essa razão, o autor aceita certas transcendências especiais na imanência da consciência pura, tal é o caso do ego transcendental.

Levando isso em consideração, é possível notar que a discordância de Sartre em relação a Husserl é anterior aos resultados e incide também no método de pesquisa. Sua reflexão pura é uma versão mais rigorosa, ou mesmo radicalizada, da reflexão fenomenológica. Ela só aceita a evidência adequada da vivência atual. Segundo o autor francês, apenas essa reflexão pode explorar a consciência constituinte em sua pureza máxima, delimitando o campo de constituição da experiência sem nele acrescentar nenhuma transcendência que extrapole os dados do vivido. O resultado da reflexão pura, assim concebida, já conhecemos; a expulsão de toda transcendência da imanência do campo transcendental. É através da reflexão pura que o Ego será estabelecido como um objeto transcendente para a consciência. Sartre irá chamar de reflexão impura toda aquela que extravasa os puros dados da vivência em suas afirmações. Para este autor, toda reflexão que encontra um Eu na consciência é impura. Portanto, em linhas gerais, a distinção do procedimento das reflexões pura e impura é a seguinte: a primeira é simplesmente descritiva, devolve a instantaneidade da consciência irrefletida. Já a segunda é cúmplice, opera uma passagem ao infinito e, a partir de uma vivência, constitui um objeto transcendente (por exemplo, um estado, como será mostrado nas próximas páginas).

Para quem lê o ensaio sobre $A$ Transcendência do Ego, o tema da reflexão pura pode passar desapercebido, já que o autor faz apenas uma breve menção ${ }^{34}$ sobre o seu critério de evidência. No entanto, esse é um tema importante para quem quer acompanhar a evolução do pensamento sartreano no que concerne à temporalidade. Por um lado, é verdade que a reflexão pura está de acordo com o sistema de pensamento do autor nesse artigo. A própria supracitada distinção entre atitude reflexiva e prérreflexiva possibilita a

\footnotetext{
${ }^{34}$ No item A da segunda parte do artigo.
} 
distinção entre reflexão pura e impura. Quando Sartre afirma que a reflexão modifica irreversivelmente a consciência, ele está apontando para como a volta da consciência sobre si sempre traz, para a consciência refletida, elementos que lhe são estranhos e que pertencem, na verdade, à própria consciência reflexionante. Portanto, a adoção do critério da reflexão pura é uma tentativa de evitar a ameaça da inclusão de elementos transcendentes na consciência que é inerente ao próprio ato reflexivo. Por outro lado, o fato de Sartre não permitir gradações na evidência a ser aceita, faz com que sua única opção seja adotar aquilo que é restrito ao instante. Também já foi citada essa tendência do pensamento do jovem Sartre de se ater excessivamente ao momento presente. Nesse ponto, o critério de evidência perde a fluidez temporal da consciência, limitando o exame do pensamento ao instante. Isso é mais um reflexo da dificuldade que o autor tinha para trabalhar com a temporalidade. Também é cúmplice da tese de criação ex nihilo da consciência que o autor sustenta no opúsculo sobre a Transcendência do Ego. Nas próximas seções, pretendo expor a descrição fenomenológica do Ego realizada por Sartre. Só é possível compreender essa descrição tendo em mente a distinção entre reflexão pura e impura. No momento adequado, farei mais apontamentos sobre as dificuldades advindas da criação ex nihilo para a compreensão das dinâmicas do ser psíquico que passará a ser descrito logo a seguir. 


\subsection{Eu é um outro}

Queria apenas tentar viver aquilo que brotava espontaneamente de mim. Por que isso me era tão difícil? (Herman Hesse, Demian)

\subsubsection{Descrição fenomenológica do Ego.}

O tema da descrição do Ego se encontra na segunda parte de T.E., intitulada de “Constituição do Ego". Como foi mostrado, na primeira parte do artigo o autor se dedicara a negar a presença do Eu no interior da consciência. Mas isso não significa que Sartre negue a existência de toda forma egológica, o que ele não aceita é a participação dessas formas na estrutura da consciência pura, de modo que mediassem sua relação com o mundo e sendo, assim, um elemento de opacidade. Para Sartre, o Eu só existe na vida psíquica, objeto transcendente da consciência transcendental. Por essa razão, o autor dedicará a segunda parte da obra para descrever a natureza do ser psíquico segundo o procedimento fenomenológico. A partir desse momento no texto, Sartre não falará mais em $\mathrm{Eu}$ formal ou Eu material, mas em Ego. No final da primeira parte, o autor já nos adianta que o Eu e o "Mim" não são senão a dupla face daquilo que ele irá chamar de Ego, respectivamente a face ativa e passiva. "O Eu é o Ego como unidade de ações. O 'Mim' é o Ego como unidade de estados e qualidades". (SARTRE, 2003b, p. 107) Estados, ações e qualidades são os elementos que formam a vida psíquica e que encontram no Ego sua síntese transcendente. Até este momento, a reflexão sartreana almejou mostrar que as estruturas egológicas não fazem parte da imanência do campo transcendental. A consciência intencional permanece vazia de qualquer conteúdo, até mesmo do Eu. No entanto, Sartre não nega por completo a existência do Ego (entendido como a unidade de suas facetas Eu e Mim). A tese do autor não consiste em erradicar, mas sim em deslocar a posição do Ego em relação à consciência. Não mais um habitante interno, ou uma estrutura centralizadora do campo transcendental, o Ego será encontrado no campo transcendente e seu modo de existência só será notado no plano reflexivo. Lembremos: no plano irrefletido a consciência, através de seu fluxo temporal, realiza de modo espontâneo sua própria unidade, enquanto que do lado do transcendente o próprio objeto aparecia como unidade real das visadas intencionais. Porém, no plano reflexivo a unidade das consciências refletidas não parece ser mantida por seu próprio processo interno. Aparentemente, as vivências refletidas encontram sua unidade num objeto que aparece 
por e em cada uma delas, mas que transcende a cada uma em particular. Esse objeto é exatamente o Ego, ele aparecerá como a unidade das consciências refletidas, de maneira análoga ao objeto no plano irrefletido, ambos se manifestarão como polo-objeto. A diferença é que o Ego será unidade indireta mediada pelos estados, ações e qualidades. Seguirei o texto analisando a descrição desses três elementos que constituem a estrutura do campo psíquico.

\section{Os estados}

Sartre define um estado em oposição a um sentimento instantâneo, pontual. O exemplo fornecido pelo autor é o sentimento de ódio. Tomemos, por exemplo, o ódio a Pedro. O ódio está para além do sentimento pontual de repulsa (este instantâneo) que eu tenho ao ver Pedro na consciência irrefletida. Quando estabelece essa ponte entre a vivência instantânea de repulsa para o perene ódio, o estado é, em certa instância, uma projeção das vivências refletidas. Já que ele é a qualificação atemporal de uma vivência pontual, o estado é um nome fixo que se dá para cada fugidia alteração emocional. No sentimento, ou melhor, no estado de ódio, eu suponho que sempre odiei e sempre vou odiar Pedro, fica então evidente que essa é uma consciência reflexiva que extrapola a consciência espontânea de repulsão. Podemos notar que, embora seja real, o estado não é apreendido através de uma evidência certa e adequada. Em outras palavras, o estado não participa da certeza intuitiva que Sartre credita à reflexão pura. Mais do que isso, o estado é fruto da reflexão impura, que extrapola o instante presente e faz afirmações sobre o passado (já odiava Pedro) e, notadamente, projeções sobre o futuro (continuarei odiando Pedro). Portanto, ao considerarmos o estado, estamos diante de uma intuição muito diferente daquela fornecida pela instantaneidade do sentimento de repulsão (que, obviamente, é certo e evidente). Sartre admite que o ódio seja simultâneo à experiência de repulsão, pois ele se dá mediante tal experiência. No entanto, ele não se limita a nenhuma experiência concreta. Isso significa que apesar do estado se dar em e por cada vivência concreta, ele não se retém em nenhuma delas, ele não é nenhuma delas, uma vez que as transborda afirmando sua continuidade para além de toda vivência particular. Por essa razão Sartre afirma que o estado é um ser transcendente, pois ele não se reduz a nenhuma de suas manifestações particulares. Com isso, o autor quer dizer que em um 
estado há a distinção entre ser e aparecer ${ }^{35}$, logo ele não seria aquele fenômeno puro tal qual as vivências da consciência. Por aqui, Sartre já pode definir que um estado não é $d a$ consciência.

A relação do estado com a consciência está intimamente ligada com o problema das evidências. Para o autor, fazer a distinção entre reflexão pura e impura, significa retornar a um exame crítico dos próprios direitos da reflexão. $\mathrm{Na}$ diferença entre evidências adequadas e inadequadas se encontram os limites de direito da reflexão. Para Sartre, apenas as conclusões da reflexão pura respeitam esses limites de direito, pois se apoiam nas evidências certas que o instante oferece à intuição. Já o estado, enquanto produto forjado pela reflexão impura, carrega sempre um elemento de dubitabilidade. Por exemplo, é sempre certa a repulsa que senti por Pedro. Porém, quando, a partir do dado desta evidência, a reflexão constitui o estado (o ódio por Pedro), estamos diante de uma evidência incerta, que poderá sempre ser contestada por uma vivência ulterior. Posso acordar amanhã e perceber que, de fato, não odeio Pedro, eu apenas estava irritado naquele momento. Ambas as reflexões (pura e impura) apreendem os mesmos dados certos (a repulsa do instante), mas a reflexão impura afirmou mais e por isso seu produto sempre carregará este elemento de dúvida. Desta maneira, o objeto da reflexão, o estado, compartilha de seu fator dúbio. Este é mais um argumento de porquê o estado não ser da consciência, pois, sempre certa de si, a consciência pode, potencialmente, sempre se enganar em relação a seu estado. Sendo assim, o estado se mostra como sendo algo para a consciência; ele lhe é um objeto.

Continuando o exame do estado, Sartre afirma que essa forma psíquica é uma passividade, já que é constitutiva da reflexão (e não constituinte). O autor admite que um estado, como o ódio, possa assumir uma força, na medida em que influencia as ações do sujeito, porém seria uma força inerte, semelhante às forças de natureza física (tal qual a corrente elétrica ou a queda d'água, nos exemplos do próprio Sartre). Tais forças, apesar de serem terríveis, não são causa de si, já que recebem sua energia de fora. Para Sartre, isso é razão suficiente para afirmar que tanto essas forças da natureza, quanto aquela advinda do estado, são inertes e passivas. Essa comparação com as entidades da natureza é bastante significativa, principalmente pelo atributo de inércia que Sartre lhes atribui. A

\footnotetext{
35 "Ele (o estado de ódio) opera por si mesmo uma distinção entre ser e aparecer já que ele se dá como continuando ser mesmo quando estou absorvido em outras ocupações e que nenhuma consciência o revela." (SARTRE, 2003b, p.109).
} 
inércia é tida pelo filósofo como uma das principais características que descreve o modo passivo de existir do mundo material. Logo no primeiro parágrafo da introdução de $A$ Imaginação $o^{36}$, o autor afirma que o ser em si se define pela inércia de suas qualidades sensíveis, pois essa característica se opõe diretamente à espontaneidade que define o ser consciente do para si. Esse tipo de oposição vai perdurar em O Ser e o Nada e no resto do conjunto existencialista do autor. Portanto, quando Sartre aproxima em T.E. o modo de existir do estado com o das forças físicas pela passividade inerte que ambos compartilham, o autor está elencando mais um dos motivos para recusar os estados como seres da consciência. Lembremos que a tese da não naturalização da consciência perpassa por todo o ensaio sobre o Ego. Desde o artigo sobre a Intencionalidade, a consciência vem sendo definida como um ente insubstancial e imaterial, cujo modo de existir se define pela espontaneidade. Espontaneidade, aqui, significa não ser determinada por nada, não sofrer causalidade, pôr-se a todo instante na existência (daí a crição ex nihilo). Desse modo, a passividade é mais um dos argumentos para considerar o estado fora da consciência. Ele é inerte, portanto, ele nada desvela, mas se oferece ao desvelamento para uma atividade consciente, em outras palavras, ele aparece para a consciência; é um objeto transcendente.

Seguindo o texto, Sartre afirma que o estado é dado como intermediário entre o corpo e a vivência. Porém, o modo dessa intermediação não é dado da mesma forma no corpo e na consciência. No corpo ele seria a "causa dos gestos" (ser desagradável com Pedro). Quanto à consciência, Sartre faz uso da noção de “emanação". Pois, aqui, parece que a vivência espontânea emana do estado (o sentimento de repulsa aparece por eu já odiar Pedro). Mas ocorre que essa aparição está invertida, uma vez que a anterioridade pertence à consciência irrefletida de repulsa e o estado de ódio seria apenas sua projeção para o futuro (a partir desta repulsa, continuarei odiando Pedro nos encontros futuros). Mas ocorre que a consciência apreende esse processo de maneira invertida, pois a relação entre a aparição do sentimento e a consciência é inerentemente confusa. Sartre chama esse processo de ligação "mágica". Aqui o autor pretende combater aqueles psicólogos que entendem que a inversão da aparição do estado e da vivência aconteça de fato e não seja uma peculiaridade da maneira pela qual a consciência apreende suas vivências. "Mágico", para Sartre, é todo o processo de constituição de sentido, realizado pela

\footnotetext{
${ }^{36}$ SARTRE, J. P. L'imagination. Paris: PUF, 2010.
} 
subjetividade, que não seja racional. No Esboço para uma teoria das emoções, por exemplo, mágica descreve a maneira pela qual a consciência emocionada tinge o mundo com suas próprias cores ${ }^{37}$. Ou seja, quando a consciência realiza uma operação mágica, ela está passando por cima das relações reais estabelecidas entre os objetos e substituindoas por uma relação irracional. Em T.E., afirmar que a ligação entre o estado e sua vivência seja mágica, significa dizer que a precedência do estado não é real, não é uma relação lógica, mas apenas fruto de peculiaridades da dinâmica da própria subjetividade ${ }^{38}$. É verdade que, devido à "concessão" feita à força que o estado exerce nas vivências do sujeito, torna-se, no mínimo, emaranhada a compreensão do processo pelo qual os estados influenciam as vivências, uma vez que se queira manter a tese da prioridade do irrefletido. Mas Sartre mantém sua tese da consciência irrefletida como primeira e autônoma. Portanto, em T.E., quando se fala em relação mágica, esse termo sempre carregará um teor pejorativo em relação aos psicólogos contra os quais Sartre se embate “...de maneira geral, as referências à magia são de ordem pejorativa. Sartre mantém, de início, o mágico como vetor de ilusão ou de alienação. ${ }^{39}$ De qualquer modo, o ensaio sobre o Ego apenas cita essas questões de maneira muito breve. Esse tema só será mais bem desenvolvido no Esboço para uma teoria das emoções. Voltarei a comentar esse tema no último capítulo desta dissertação, por hora nos interessa apenas as questões pertinentes à constituição do estado.

Concluindo as considerações sobre o estado, podemos afirmar que ele é a síntese transcendente de várias vivências pontuais, e é apreendido intuitivamente pela consciência reflexiva. Portanto, assim como o Eu, ele não faz parte da estrutura da consciência intencional; o estado é uma síntese transcendente.

\section{As ações}

Após a apresentação do estado, Sartre se dedica ao exame das ações. Assim como o estado, a ação também é uma síntese transcendente. Síntese de gestos isolados que como consciência reflexiva transcende a consciência ativa de cada um. Ou seja, há um conjunto de atos sucessivos no tempo que, quando apreendidos pela consciência reflexiva, são

\footnotetext{
${ }^{37}$ Ver capítulo 4 desta dissertação.

38 "A equação entre psicologia e magia toma, assim, um sentido depreciativo, sobre o qual devemos nos atentar, pois a categoria do mágico flerta com o equívoco." (COOREBYTER, 2000, p. 486).

39 Idem nota 38, p. 487.
} 
sintetizados como uma ação. Por exemplo, vamos considerar a ação "beber água", segurar o copo nas mãos, abrir o filtro, enchê-lo d'água, por fim, verter o conteúdo do copo garganta abaixo, cada um destes momentos seria os gestos isolados que, apreendidos pela consciência reflexiva, são sintetizados como o ato "beber água". Não são transcendentes apenas as ações em que interagimos com o mundo exterior das coisas, o mesmo também vale para as ações psíquicas, como o ato de duvidar, raciocinar, etc., pois o objeto da ação continua sendo uma unidade noemática. O que constitui a ação são os momentos que ocorrem no fluxo do tempo, e que são ulteriormente apreendidos pela reflexão como uma ação total. "A estes momentos correspondem consciências concretas ativas e a reflexão que se dirige sobre as consciências apreende a ação total em uma intuição que a entrega como unidade transcendente das consciências ativas." (SARTRE, 2003b, p.112).

Esse é outro momento do texto, cuja análise traz dificuldades. Sartre afirma que quando a reflexão se dirige sobre as consciências ela já apreende a ação total. Desse modo, a sucessão dos gestos isolados parece concorrer naturalmente para a realização da ação. Mas, em cada um desses momentos teríamos a atividade da consciência irrefletida, o que significa espontaneidade e, como já vimos, criação ex nihilo. Ou seja, se as consciências irrefletidas e espontâneas se seguem a partir do nada, então o que garantiria a coesão entre elas, por que não esperar resultados completamente imprevisíveis ${ }^{40}$

O que parece salvar as ações da aleatoriedade é a distinção entre consciência ativa e meramente espontânea. Segundo Sartre, os momentos da ação são correspondidos por consciências ativas, isso nos livraria da possibilidade de uma sequência de ações ilógicas, governadas pela imprevisibilidade de consciências espontâneas quaisquer. Porém, o autor não define o que seja a consciência ativa, assim sua natureza não fica clara. "Nós não tentaremos estabelecer uma distinção entre a consciência ativa e a consciência simplesmente espontânea. Parece-nos, aliás, que é um dos problemas mais difíceis da fenomenologia." (SARTRE, 2003b, p. 112).

\footnotetext{
40 "Cada uma das fases da ação complexa 'tomar água'(...) se atesta com evidência no instante em que ocorre (...) Afinal, para Sartre cada vivência brota na consciência a partir do nada; nenhuma delas foi antecipada ou preparada por nada e, por sua vez, nenhuma delas anuncia ou antecede alguma vivência em particular. Que após eu não encontrar nenhum copo à disposição eu abra um armário para procurar um recipiente para a água é uma contingência absoluta. Se em vez de abrir o armário eu tivesse pulado da janela do apartamento ou esfaqueado um vizinho, ou mesmo se a ordem das vivências no exemplo acima se alterasse, não haveria, em nenhum desses casos, porque se surpreender.” (SACRINI, 2012, p. 120).
} 
Especulo que uma consciência ativa esteja relacionada com a volição (tema que Sartre não trata em nenhum momento de seu artigo). Talvez essa consciência seja aquela precedida por uma decisão autoconsciente (irei beber água). E essa consciência de si do ato volitivo não é necessariamente tética, pois na vida corriqueira a consciência está imersa no mundo e ela não se limita a observar, mas vive nesse mundo. Desse modo, quando decido correr para pegar o trem, a decisão de correr pode ser realizada por uma consciência ativa que não toma seu ato volitivo de maneira posicional. Quase automaticamente, corro para pegar o trem, pois diante de minha consciência está o objeto noemático trem-saindo-da-estação. Portanto, pelo menos até aqui ${ }^{41}$, a volição também pode ser irrefletida. Mas, qualquer que seja a natureza desse tipo de consciência, o que fica claro no texto sartreano é que os momentos de uma ação são regidos por um tema diretor (beber água). Parece que é esse tema diretor que confere a coesão das consciências ativas. Desse modo, nos momentos da ação, a sucessão ex nihilo é, de alguma forma, coordenada por esse tema, isso impede uma vida completamente contingente. O que fica claro é que desde o ensaio sobre o Ego, Sartre compreende que a vida psíquica é baseada em condicionamentos e segue certas tendências. No entanto, o critério de evidência exigido pela reflexão pura acaba estreitando essa compreensão. Por essa razão, nas obras futuras, Sartre não trabalhará mais com tal critério. Nos textos sobre psicologia fenomenológica o autor já irá considerar uma espessura temporal maior na vida psíquica. O tema diretor da ação, por exemplo, parece adiantar o conceito de finalidade apresentado em E., na medida em que coordena temporalmente a vida psíquica. Como venho reiterando, todo o tema psíquico voltará a ser elaborado nos livros sobre a Imagem e, principalmente, em E., no momento oportuno voltarei a abordar essas questões. Por enquanto, para a tese de T.E., o que importa frisar é que a ação é, enquanto unidade noemática que transborda seus sucessivos momentos, uma transcendência tal qual o estado.

\section{As qualidades}

Sartre afirma que a qualidade é uma potencialidade cuja atualização seria o estado (ou, na menor parte dos casos, a ação). Por exemplo, a manifestação de vários estados

\footnotetext{
${ }^{41}$ Em $O$ Ser e o Nada e, notadamente, no quarto capítulo desta dissertação, a questão da volição na consciência ativa será melhor explorada.
} 
coléricos implicaria na qualidade de um indivíduo ser rancoroso ou colérico. De maneira geral, as qualidades são sínteses mais amplas que definem o que se chama de personalidade, pois, diferentemente dos estados, as qualidades se referem ao sujeito que as vivencia e não aos objetos com os quais este se relaciona. Isto é, o estado de ódio está ligado a Pedro (ele é odioso), já a qualidade está associada a mim enquanto vivo diversos estados similares (sou colérico já que odeio Pedro, Paulo e tantos outros). Pode-se notar que existe uma ligação profunda entre a qualidade e os estados, na qual a primeira vem a ser a mediação entre os segundos e o Ego. Essas unidades transcendentes que venho descrevendo podem ser o Ego diretamente (no caso dos estados ou ações), ou indiretamente (quando intermediadas pela qualidade). Sartre ainda diferencia essencialmente qualidade e estado. Embora ambos sejam sínteses transcendentes, a relação de ambos com os termos que unificam é essencialmente distinta. Enquanto o estado tem uma relação de emanação com as vivências ("na ausência de toda consciência de ódio, o ódio se dá como existente em ato" (Idem, p. 113)), a qualidade, ao contrário, na ausência de seu estado correspondente, permanece uma potencialidade. Sendo assim, no lugar de se referir à qualidade como síntese, é mais apropriado defini-la como potencialidade. Numa última consideração, na medida em que sua atualização é o estado, a qualidade também é transcendente e se mostra como intermediária entre o Ego e suas vivências.

\section{Constituição do Ego}

Logo após ter descrito os estados, ações e qualidades, Sartre afirma ter realizado a distinção entre o psíquico e a consciência. Isso significa que o autor estabelece uma separação entre duas esferas, uma é a consciência transcendental pura (domínio de estudos da fenomenologia), a outra se delimita pelas vivências afetivas, objeto transcendente da primeira esfera e se trata do ser psíquico (domínio da psicologia). Uma vez definida essa separação, Sartre afirma que o Ego é a síntese unificadora do campo psíquico. Em outras palavras, o Ego seria o referencial de unidade de todos os estados, ações e qualidades, um objeto transcendente para a consciência pura que é apreendido através da reflexão como o sujeito da vida psíquica, pois dele parecem emanar os estados e ações. No entanto, deve-se desconfiar da maneira pela qual a consciência apreende, mediante a reflexão, suas próprias vivências. Na apreensão do Ego, estaríamos mais uma 
vez diante do fator dúbio que é intrínseco à evidência reflexiva. Pois, para a consciência reflexiva, o Ego transcendente realiza a síntese das vivências, no entanto esta mesma tarefa de síntese é aquela que lhe havia sido negada no plano transcendental. Vimos que a consciência não necessitava do recurso ao Eu para se unificar, mas, ao contrário, o Eu material ou formal era nocivo à concepção fenomenológica de consciência e, através da intencionalidade, a consciência foi "liberada" de todo conteúdo e o Ego foi estabelecido como seu objeto transcendente. Como explicar, agora, este novo papel concedido ao Ego? Para desfazer essa aparente confusão, Sartre explica detalhadamente como o Ego é constituído pela própria consciência reflexiva.

Ocorre que a reflexão impura apreende de maneira retroativa suas vivências, desse modo ela "vê" a cadeia consciências-estados-Ego de maneira invertida; as primeiras emanando dos segundos que, por sua vez, aparecem como que produzidos pelo último. Mas, como Sartre já havia afirmado, o que é realmente primeiro é a consciência transcendental, espontânea e irrefletida. A reflexão é o ato de uma consciência de segundo grau, portanto seus elementos constitutivos não podem preceder a pureza do plano irrefletido. Ou seja, as determinações do Ego não podem influenciar o ser espontâneo da consciência irrefletida. Adiante pretendo mostrar como Sartre resolve essa aparente confusão através da exposição minuciosa da espontaneidade da consciência e de como ela constitui seu objeto Ego.

Em primeiro lugar, Sartre define o tipo de síntese que o Ego realiza da vida psíquica. O autor elabora sua definição em oposição à síntese descrita por Husserl do noema em relação aos seus predicados. Sartre chama a síntese husserliana de polo-objeto, $\mathrm{X}$ suporte de predicados. Para o filósofo alemão, o noema é o ponto de unidade central de seus predicados. Ele é o ponto de ligação, mas não se identifica com a unidade de cada um deles. Portanto este ponto $\mathrm{X}$ é distinto dos elementos que unifica (embora não possa ser separado deles). Por sua vez, Sartre afirma que o Ego é uma "totalidade sintética indissolúvel” que se suportaria a si mesma sem a necessidade deste X suporte. O autor propõe uma analogia com a melodia musical em relação às suas notas: "É inútil, por exemplo, se considerarmos uma melodia, supormos um $\mathrm{X}$ que serviria de suporte às diferentes notas. Aqui a unidade vem da indissolubilidade absoluta dos elementos que não podem ser concebidos separadamente, a não ser por abstração" (SARTRE, 2003a, p. 114-115). 
Não é por acaso que Sartre defina sua concepção de "totalidade sintética" em oposição a este suporte que Husserl coloca no núcleo noemático. Em se tratando do Ego, o perigo dessa concepção seria de tomá-lo por uma entidade separada de seus predicados (os estados e ações). Neste caso, o Ego estaria muito próximo daquela imagem metafísica da pessoalidade; uma substância pensante, ente individual, efetivamente existente e sujeito da consciência. É exatamente essa tese que T.E. tenta combater. Sartre tem plena consciência de que a unidade dos predicados de Husserl pode ser confundida com a unidade de um sujeito individual. "Seria tentador constituir o Ego em 'polo-sujeito' como este 'polo-objeto' que Husserl coloca no centro do núcleo noemático" (Idem, p. 114). Por essa razão, o filósofo francês dedica uma atenção especial em mostrar como a natureza sintetizadora do Ego não se aproxima desse conceito husserliano. Através dessa diferenciação, Sartre poderá mostrar que aquilo que ele entende por Ego não tem a forma de um sujeito, não possui nenhuma realidade para além de seus predicados, como se estivesse neles dissolvido. Apenas essa imagem do Ego está de acordo com a autonomia da consciência espontânea estabelecida pelo autor. $\mathrm{O}$ Eu deve se assemelhar à imagem formada por um quadro pontilista. Se olharmos mais de perto, ela é constituída por vários pontos distintos em cor e forma, que não encontram sua unidade em nenhum local específico, não se colam entre si e nada de fora os unifica. Nada liga os pontos para que eles formem uma imagem, ao contrário, a própria imagem é sua síntese. A imagem não se reduz a nenhum dos pontos, ao mesmo tempo ela não é a soma deles. No quadro de Seurat, Domingo na Ilha da Grande Jatte, as pessoas que aproveitam o domingo ensolarado não existem por si mesmas, elas são figuras constituídas pela retina que justapõe as cores dos múltiplos pontilhados. A dama com sua sombrinha não é, de modo algum, a soma de todos os pontos ou sua unidade ideal, ela é um sentido que a visão constitui através das manchas de cor. Da mesma forma, o Ego só existe quando a consciência reflexiva constitui uma síntese de seus diversos estados, "vendo" assim a imagem coerente de um Ego. A síntese é este sentido de unidade que transcende cada um de seus elementos.

Para deixar clara essa sua posição, Sartre distingue o Ego do X suporte a partir de três argumentos: comprometimento, transcendência e indistinção.

Por ser suporte, o tal $\mathrm{X}$ seria indiferente às qualidades psíquicas que suporta. No entanto, o Ego é comprometido por seus estados, pois eles exercem influência sobre a conduta e a disposição do sujeito (se constato meu ódio por Pedro, é provável que 
continue sentindo repulsa a cada vez que o ver, eu serei desagradável com ele). Comprometimento, aqui, significa que o ser psíquico é sensível à sua história vivencial, as transformações de seus predicados se correlacionam com suas próprias.

Quanto à transcendência, Sartre afirma o seguinte. O Ego não é nada fora os estados e qualidades dos quais é síntese, no entanto ele aparece para a consciência de segundo grau como transcendendo a todo estado, no sentido em que nunca se deixa reduzir a uma ação ou estado pontuais, mas é antes sua "totalidade infinita", como o é o mundo em relação a todas as coisas. Portanto, o Ego, na forma como se mostra, transcende seus predicados, ao contrário do $\mathrm{X}$ abstrato, e não existe para além da unificação que realiza.

Por fim, o Ego não se distingue de seus estados e ações, de sorte que os mesmos não podem ser pensados sem ele. Indistinção, aqui, significa que o sujeito psíquico se identifica com seu próprio ato. Numa formulação como "Eu sou amoroso", estes termos só podem ser separados por abstração. O Eu não teria uma existência separada de seu ato amoroso. Pelo contrário, no momento da formulação, ele existe na forma de amorosidade. Pois tanto a existência do estado, quanto a do Ego, não teriam sentido se ambos os termos não fossem ligados imediatamente um ao outro sempre que se pensa neles. Portanto, o Ego sintetiza a vida psíquica de modo bem particular, não se reduz à unidade de seus elementos embora não seja nada sem eles, além de com eles compartilhar de certa cumplicidade. Ele é, certamente, muito diferente de um polo de unidade abstrato.

É interessante notar que a relação do Ego com as qualidades, estados e ações não é uma relação de emanação, nem de atualização, é uma relação de produção poética ${ }^{42}$, no sentido de construção articulada. Desta maneira, os estados se reportam ao Ego como à sua origem. O Ego se mostra como criador e mantenedor dos estados, qualidades e ações, numa criação ex nihilo. No entanto, em coerência com o que foi dito acima, o Ego não é apreendido como algo para além daquilo que cria, se fossem retiradas cada uma de suas qualidades, nada restaria. Em uma palavra, o Ego aparece como uma espontaneidade criadora, indistinta disto que cria, no entanto, não se limitando a nenhuma criação concreta.

\footnotetext{
${ }^{42}$ SARTRE, 2003b, p. 116.
} 
Ora, o Ego realiza a síntese do campo psíquico de maneira espontânea. Isto nos coloca diante de outra dificuldade, pois a espontaneidade era característica apenas da consciência. Como manter, então, a distinção entre consciência e $E g o$, uma vez que este último realiza espontaneamente a síntese das vivências transcendentes, compartilhando, assim, dessa característica que era exclusiva da consciência e do campo transcendental? Devemos compreender como funciona essa espontaneidade. $\mathrm{O}$ fato é que o Ego não pode ser espontâneo tal qual a consciência, pois, “A noção justa de espontaneidade afasta a possibilidade de ligação 'sintética' entre ela e outra coisa, tal como há entre o Ego e o estado." (MOUTINHO, 1995b, p. 40). Além disso o Ego é um objeto e, enquanto tal, é passivo. É passivo, inclusive, em relação àquilo que cria, uma vez que ele é comprometido pelo estado. Por tais motivos, Sartre recusa a reconhecer no Ego uma verdadeira espontaneidade, aquela que não é determinada nem causada por nada, condição exclusiva do ser da consciência. Sendo assim, o autor dirá que a espontaneidade do Ego é bastarda e degradada. A causa disso é a maneira pela qual a consciência reflexiva apreende e constitui o Ego, através da reflexão impura. É uma constituição inversa, em relação à ordem em que os estados são constituídos pela consciência. Como já foi dito, a consciência, que é realmente primeira, aparece como que emanando dos estados, e estes como que produzidos pelo Ego. Mas o que realmente ocorre é que a consciência reflexiva, quando se dobra sobre si mesma, inverte a cadeia de aparições e projeta sua espontaneidade para seu próprio objeto, isto é, o Ego. Trata-se, então, de uma falsa espontaneidade, ou melhor, uma espontaneidade passiva uma vez que é ele (o Ego) que foi constituído.

Todas essas confusões ocorrem porque o Ego é constituído pela reflexão impura, que significa aqui reflexão constituinte. O problema é, então, como a consciência constitui o Ego, sendo que ela não pode produzir nada senão ela mesma. Acontece que a consciência reflexiva se projeta no objeto Ego para "fugir de sua própria espontaneidade", isso significa que o Ego não é nada mais que a projeção invertida da própria consciência em relação às suas vivências, sendo assim, a espontaneidade em questão é aquela da própria consciência, que se mascara por meio da reflexão constituinte. A consciência não constitui o Ego como algo diferente de si, de maneira que se poderia ocorrer uma ligação sintética. O que ocorre é que as consciências já unificadas no plano da espontaneidade irrefletida, quando submetidas à reflexão que apreende o encadeamento das vivências de maneira invertida, são projetadas e hipostaseadas no Ego. Em outras palavras, a reflexão 
impura constitui o Ego quando representa uma síntese já operada pela consciência de maneira espontânea no plano irrefletido. "No fundo, trata-se apenas de uma só e mesma síntese, realizada no nível ainda da consciência: é a consciência já unificada que é projetada como Ego.” (Idem, p. 42). Isso significa que o Ego não é um ente efetivamente real (embora se doe através de uma intuição concreta) e distinto da consciência, ele é apenas a maneira pela qual ela representa sua própria síntese que, no plano irrefletido, ocorre espontaneamente.

A aparição do Ego só acontece quando da apreensão reflexiva do psíquico, isso mostra que ele não é uma estrutura interna da consciência, ao contrário, é um ser que aparece ao lado do psíquico, sua existência se limita à vida afetiva. Por sua vez, a vida afetiva corresponde às relações que a consciência estabelece com o mundo, além das epistemológicas. Todo esse domínio afetivo acontece numa segunda instância se comparado com a consciência transcendental pura, ele é apenas um objeto desta última. A partir daqui podemos tirar duas conclusões sobre o Ego. Em primeiro lugar, ele deixa de ser o centro da consciência e da personalidade, ele não pode mais ser identificado com o sujeito metafísico, pois sua existência se limita à apreensão dos vividos afetivos. Longe de ser uma substância autônoma, o Ego é apenas a maneira pela qual a consciência organiza sua própria vida afetiva. Da necessidade de se encontrar um remetente perpétuo para a unidade dos estados, que é realizada de modo espontâneo no plano irrefletido, a consciência reflexiva constitui o Ego como se fosse o sujeito de suas vivências. Em outras palavras, o Eu é a ficção teleológica da consciência, é apenas o modo como ela mascara para si própria a contingência de sua autocriação continuada, seu vir a ser perpétuo e espontâneo. Em segundo lugar, e este ponto é particularmente caro para a ética realista de Sartre, a identidade pessoal não existe, de modo algum, nas profundidades do espírito. Uma vez identificado como o psíquico, objeto da consciência transcendental, o Ego é transcendente e mundano, suas aparições são contemporâneas ao mundo, logo, é dessa exterioridade que sua vida tira todo seu sentido. Portanto, aqui temos uma continuidade do projeto de purificação da consciência iniciado em $I$., nada permanece na consciência, tudo está no mundo, até mesmo a identidade pessoal. 


\subsubsection{Um sujeito impessoal}

A tese contida em T.E. é um marco para as teorias do sujeito. Segundo Coorebyter ${ }^{43}$, esse texto chegou a ser visto como o primeiro sinal da "morte do sujeito", tema que predominaria na filosofia francesa durante o estruturalismo e depois. De fato, a consciência anônima instituída nessa obra traz algumas repercussões para o modo como se pensa tradicionalmente a subjetividade. A seguir, pretendo trabalhar alguns pontos relacionados com essa questão.

A separação feita entre o campo transcendental e o psíquico, que se traduz na distinção entre consciência e Ego, implica claramente uma cisão entre o fluxo consciente e a identidade pessoal. Isso significaria o fim do sujeito? O estabelecimento de uma impessoalidade inconsciente de si, atirada a um relacionamento passivo com os processos de subjetivação do mundo? Acredito que não. Mas, se não há na obra de Sartre uma extinção plena sujeito, certamente há, no mínimo, uma reformulação dessa noção. Como já adiantei acima, parece que o autor transfere para a própria consciência algumas das características que tradicionalmente eram atribuídas ao sujeito, ao mesmo tempo em que relativiza a noção de Eu. A melhor maneira de compreender esse processo é entendendo a ausência da substância pensante no interior da consciência. O Eu penso é a entidade realmente anulada pela tese sartreana, pelo menos no plano primordial da consciência irrefletida. Desde o esvaziamento da consciência realizado em $I$, até a crítica ao Eu puro feita em T.E., Sartre tenta mostrar que não existe nenhuma estrutura egológica habitando o interior da consciência, regendo seus processos e intermediando sua relação com o mundo. $\mathrm{O}$ resultado disso é a completa autonomia da consciência no que concerne à sua dinâmica existencial e sua abertura ao mundo. O ser da consciência é a existência absoluta e o Eu, apenas seu objeto. O sujeito entendido como o Eu substancial, do qual emanaria a consciência, simplesmente não existe. Mas isso não implica numa anomia absoluta, a consciência é individuada e cria suas próprias tendências, seus vícios, sua "personalidade", ou melhor, idiossincrasia, conforme é descrito na exposição sobre os estados e as qualidades. Tal estrutura psíquica apenas não é anterior à consciência transcendental, mas ela a acompanha ao longo de sua vida temporal. Em outras palavras,

\footnotetext{
${ }^{43}$ COOREBYTER, V. Introduction. In Coorebyter, V. (ed). La transcendance de l'Ego et autres textes phénoménologiques. Paris, Vrin, 2003. p. 7.
} 
embora consciência e psíquico não sejam identificáveis, ambos andam juntos. Tal proximidade que nunca se toca pode ser sentida por quem experimenta a introspecção.

O sentimento advindo da cisão entre o Eu e a consciência é uma angústia de saberse uma criação continuada da qual não somos os autores. O Mim está aquém da consciência, ela transborda nossa autoimagem. Até mesmo a volição é "um objeto que se constitui por e para esta espontaneidade" (SARTRE, 2003b, p. 128). A vontade nada pode sobre a consciência, esse fato pode ser experimentado por qualquer um que já tenha tentado dominar o próprio fluxo mental (tentar não pensar em algo, tentar não rir num momento inapropriado ou, ainda, acalmar a mente como nas meditações orientais). Espontânea e, às vezes, turbulenta, a consciência age e existe à nossa própria revelia. Criadora de si mesma, e autora incondicionada de sua própria história, a consciência é o que mais se assemelha à ideia de um sujeito, o Eu é apenas sua ilusão necessária, forjado para escapar de sua "liberdade vertiginosa". Sartre comenta que alguns psicólogos se deram conta dessa autonomia e anterioridade da consciência em relação ao $\mathrm{Eu}, \mathrm{o}$ problema é que eles identificaram essa dissintonia com a existência de um inconsciente do qual emanariam as consciências espontâneas. Essa tese, além de duplicar o sujeito numa forma desvelada (o Ego) e noutra velada (o inconsciente), apenas recua o problema, pois a existência das espontaneidades no inconsciente ainda precisaria de uma explicação prévia $^{44}$. Para Sartre, a consciência espontânea se produz a si própria através da criação ex nihilo, assim o suposto inconsciente pode ser explicado apenas pela autonomia e separação da consciência em relação ao Ego. A verdadeira cisão não estaria entre o consciente e o inconsciente, mas entre a vontade consciente e a espontaneidade.

Pura abertura fenomênica, essa espontaneidade da consciência não saberia existir na forma cristalizada de um Eu. Seja entendida como criação ex nihilo, ou mesmo como um fluxo contínuo, a natureza da consciência é demasiadamente dinâmica para ser identificada com uma coisa tão estática quanto a identidade pessoal. A consciência possui individualidade, isto é um fato, no entanto ela não possui identidade. Não apenas porque, sendo um fluxo contínuo, ela estaria em permanente mudança, na realidade ela nem tem o que mudar, uma vez que não é nada "já que todos os objetos físicos, psicofísicos e psíquicos, todas as verdades, todos os valores estão fora” (Idem, p. 125). É a sua existência leve que a impede de ter as características de uma pessoalidade. No entanto,

\footnotetext{
${ }^{44} \mathrm{O}$ embate com o psicologismo e com a psicanálise será comentado no capítulo 3 desta dissertação.
} 
essas características não a impedem de assumir para si alguns dos papeis que eram atribuídos ao Eu metafísico. O papel constituinte, unificante e auto producente conferem à consciência espontânea um modo de ser que se assemelha àquele de um sujeito, no sentido de ser um ente ativo que cria seu próprio modus operandi. Temos aqui uma maneira impessoal de se ser sujeito. Gostaria de deixar claro que não estou afirmando que a consciência passe a ser um novo sujeito, mas apenas que ela adquire para si algumas de suas características. O sujeito deixará de ser identificado com o Eu pensante e encontrará suas dinâmicas sendo realizadas pela própria consciência, espontânea e impessoal.

\subsubsection{Negação do solipsismo: uma ética realista.}

Na conclusão de T.E. Sartre afirma que sua concepção de Ego transcendente é a única refutação possível do solipsismo. Pois enquanto o $\mathrm{Eu}$ for uma estrutura da consciência sempre lhe é possível opor todos os outros existentes, então nenhum argumento seria suficiente para objetar a hipótese de o "Mim" ser o criador do mundo, como se permanecêssemos estacionados na segunda meditação cartesiana. A existência real de outras coisas, além de mim mesmo, nunca seria convincentemente atestada. No entanto, o Ego transcendente participa de todas as vicissitudes do mundo, uma vez que ele é um objeto para a consciência, ele é um habitante do mundo tanto quanto qualquer outro objeto e os outros "Eus". A única distinção entre meu Ego e estes últimos é apenas de intimidade e não de certeza.

A vida psíquica ocorre no mundo e mesmo os supostos interesses do $\mathrm{Eu}$ são sempre, em primeiro lugar, qualidades das coisas no mundo. Isso é o que Sartre mostra na crítica ao Eu material, quando nega que um recuo ao Mim estaria oculto em cada um dos atos da consciência. Por exemplo, se tento ajudar Pedro porque a visão de seus sofrimentos me cause desconforto, isto significaria que minha ação visa apenas suprimir um estado desagradável ao qual um certo "mim" estaria submetido e o Eu material estaria por detrás da consciência que socorre Pedro. No fundo não haveria altruísmo, eu apenas atenderia aos meus desejos. Mas, nesse caso Sartre lembra que a consciência intencional não necessita desse recuo constate ao $\mathrm{Eu}$. Ao contrário, sua vida irrefletida e imediata é sempre uma imersão no mundo. "Eu tenho piedade de Pedro e vou socorrê-lo. Para minha consciência uma única coisa existe neste momento: 'Pedro-que-deve-ser-socorrido'. Esta qualidade de 'dever-ser-socorrido' se encontra em Pedro” (SARTRE, 2003b, p. 105). Isso 
significa que os interesses da consciência são a posteriori, em primeiro lugar há um mundo repleto de sentido que reclama a ação do sujeito “(...) devemos reconhecer sem mais que a qualidade do desejo irrefletido é de se transcender à medida que apreende no objeto a qualidade desejável” (Idem, p. 106). A consciência irrefletida, o existente absoluto, é naturalmente empática. Isso não significa que ela seja naturalmente "humanista", mas apenas que reconhece primeiramente o outro para, em seguida, constituir sua identidade na relação com este outro. Portanto, sem o mundo e suas qualidades, o sujeito não saberia existir; a relação com outrem está no cerne do ser de si. É enquanto socorro Pedro que meu Mim é construído.

A referência a Rimbaud "Eu é um outro" (Id., p. 127) procura indicar que a identidade pessoal não existe no mesmo registro que a consciência. $\mathrm{O}$ Eu é outro que a consciência já que ele é seu objeto e, enquanto tal, participa de um registro de existência igual ao do mundo. Isso não apenas porque mundo e Ego são transcendências, mas também porque são copresentes, o segundo só aparece quando está relacionado com o primeiro. Essa contemporaneidade entre o Ego e o mundo implica na negação do solipsismo. Pois o Eu jamais poderia ser o criador do mundo, uma vez que a apreensão de ambos possui o mesmo grau de certeza. Por fim, o Eu perde seus privilégios metafísicos e tira da relação com o mundo e com os outros, todo o seu sentido.

Sintetizando a exposição feita até aqui, pode-se dizer que na fenomenologia sartreana o conceito de intencionalidade estabelece uma ponte entre a ontologia e a ética. E na medida em que a intencionalidade imerge ontologicamente o sujeito no mundo, o engajamento passa a tomar os ares de condição existencial mais do que de imperativo moral. O sujeito não pode existir como um ente egológico (ser do mundo), mas a partir das dinâmicas intencionais de uma consciência impessoal (ser-no-mundo). Ou seja, a dualidade entre sujeito e objeto é substituída pela totalidade consciência/mundo. Desta maneira, os indivíduos podem superar uma ontologia "cartesiana" de isolamento subjetivo, e passar a considerar uma ética baseada no comprometimento e na empatia entre si. Isto possibilita um relacionamento intersubjetivo responsável.

Para Sartre, pode-se observar que na relação objeto-indivíduo se faz necessário uma superação de um solipsismo no processo de autoconsciência; é perceber que o sujeito se reconhece em reciprocidade. Ter consciência de mim, por exemplo, encontra-se interligada em ter consciência do outro e em 
ter consciência de que este outro constrói uma consciência de mim. (MOURA, 2012, p. 19).

Sartre era plenamente ciente dessas implicações éticas apontadas por sua visão da fenomenologia. No último parágrafo de T.E., ele chega a citar uma polêmica com os "teóricos de extrema esquerda" 45 que acusariam a fenomenologia de ser um idealismo e, portanto, ser uma filosofia descompromissada com a realidade. Para o jovem filósofo, o problema destes teóricos é que eles vivem naquela velha dualidade entre ideia e matéria, correspondida pela oposição entre a consciência e o mundo. Por essa razão, os intelectuais de esquerda não poderiam ver o potencial realista da fenomenologia, pois, para eles, o realismo deve ser resultado de um "materialismo metafísico". Sartre lamenta a falta de visão desses pensadores.

Sempre me pareceu que uma hipótese de trabalho tão fecunda quanto o materialismo histórico não exigia, de maneira alguma, por fundamento a absurdidade que é o materialismo metafísico. Não é necessário, com efeito, que o objeto preceda o sujeito para que os pseudo-valores espirituais esvaneçam e para que a moral reencontre suas bases na realidade. (SARTRE, 2003b, p. 131)

Ou seja, para Sartre, o realismo não necessita do materialismo metafísico para ser fundamentado. Ao contrário, ele pode muito bem conviver com uma tese que respeite a autonomia da consciência frente à causalidade material, basta não decorrer dessa autonomia a submissão do mundo à subjetividade. Reconhecemos, aqui, o jovem que se encontrava no Bec de Gaz, desenvolvendo sua filosofia anti-idealista a partir da fenomenologia que lhe havia sido apresentada naquele encontro com Aaron. Agora entendemos o porquê Sartre acreditou que essa ciência atenderia suas preocupações de então, de ultrapassar os empasses epistemológicos entre idealismo e materialismo. Pois, a partir de seus estudos de fenomenologia, este autor pôde constituir uma imersão ontológica do sujeito no mundo. Certamente ele extravasa o projeto husserliano na medida em que começa a esboçar a constituição de uma ontologia ${ }^{46}$. Mas podemos notar como estes desvios em relação à filosofia de Husserl são dirigidos por aquele projeto que

\footnotetext{
${ }^{45}$ Provavelmente os marxistas do Partido Comunista francês.

46 "E Sartre não se satisfaz de modo algum em permanecer dentro da esfera da experiência subjetiva. Ao contrário, seu objetivo essencial é ontológico. Não apenas no sentido de que reivindica ter criado, com sua concepção do ego, 'a única refutação possível do solipsismo', corrigindo os erros de Husserl quanto a isso, mas também na medida em visa solapar o que chama de 'materialismo metafísico', abrindo o parêntese fenomenológico dentro do espírito de um 'realismo' filosófico." (MÉSZÁROS, 2012, p.101).
} 
o autor francês já possuía. E de fato, a partir da leitura do filósofo alemão, Sartre chega exatamente onde queria, ele constitui uma teoria que reconhece a presença do mundo material, na exata medida em que preserva a espontaneidade (leia-se, liberdade) da consciência humana. Por essa razão, é compreensível o entusiasmo inicial do jovem Sartre naquele bar parisiense. A fenomenologia de Husserl the permitiria superar os impasses epistemológicos que o dividiam, a partir de então o autor francês pôde renovar a teoria do sujeito, ele assegurou a autonomia da consciência e conduziu o Ego para dentro do mundo, o mundo real do sofrimento, da fome e da guerra, no qual o engajamento se torna característica constitutiva do sujeito. A partir de então "Nada mais é necessário para fundar filosoficamente uma moral e uma política absolutamente positivas.” (Idem, p. 131).

O núcleo desta primeira parte da dissertação pode ser identificada com a negação do idealismo a partir da refutação do solipsismo operada pelo conceito de intencionalidade. A seguir adentrarmos na segunda parte que é o estudo da negação do "realismo metafísico". Como foi afirmado no início do texto, o conceito de intencionalidade, uma vez que desfaz o conceito de representação, nega, simultaneamente as duas linhas epistemológicas que tinham tal conceito por sustentação. É por essa razão que o estudo de psicologia fenomenológica realizado por Sartre no fim dos anos 30 não é uma quebra temática, ao contrário, é continuidade coerente do projeto do autor. Portanto, nas próximas páginas, acompanharemos como esse estudo psicológico constituirá o momento de assegurar a soberania da consciência que, sendo atividade pura, não pode ser natualizada. 


\section{Segunda parte: "A soberania da consciência".}

\section{Do psicologismo ou o materialismo metafísico.}

\subsection{Psicologia objetivista, um novo adversário.}

Enquanto eles não se conscientizarem, não serão rebeldes autênticos e, enquanto não se rebelarem, não têm como se conscientizar. (Orwell, George. 1984)

Vimos que nas suas duas primeiras obras influenciadas pela fenomenologia, Sartre desenvolve a sua própria concepção de consciência intencional. Tentei esclarecer como a elaboração dessa noção esteve estreitamente ligada a um objetivo que era anterior à descoberta de Husserl: o escopo de formular uma tese sobre a consciência que pudesse combater o idealismo francês do início do século XX. A consciência intencional sartreana, ao anular a noção de representação e de Eu puro, faz com que o sujeito esteja ontologicamente imerso no mundo. Assim, como já foi dito, perceber uma árvore não é ter sua representação em meu interior, ao contrário, é estar em face de um ente contextualizado em seu horizonte mundano, cuja presença se impõe a mim. Em outras palavras, Sartre pretende negar o solipsismo chamando a atenção de que ter consciênciade-árvore pressupõe a existência dessa árvore anterior e independente da minha observação de sujeito. Independentemente da ação de qualquer consciência, o mundo objetivo sempre está lá, carregado de seu sentido e seus predicados; as coisas existem, tal como se dão a nós, no Bec de Gaz havia um coquetel de abricot cuja existência era um fato irredutível às consciências dos três jovens que se encontravam diante dele ${ }^{47}$. A partir do conceito de intencionalidade, o ser do mundo não fica mais submetido ao conhecer do sujeito. Portanto, Sartre lê a fenomenologia no intuito de constituir um realismo.

Mas, como eu já chamei atenção, o projeto sartreano é duplo, ele quer afirmar a presença do mundo na mesma medida em que deseja preservar a soberania da consciência. Isso significa que o autor, em sua defesa da existência do mundo material,

\footnotetext{
${ }^{47}$ Essa irredutibilidade da existência, independente da subjetividade, é o que será chamado de transfenomenalidade na introdução de $O$ Ser e o Nada.
} 
não pretende anular a consciência, ou submetê-la às dinâmicas desse mundo das coisas. Afinal, a consciência é um ser-no-mundo e não um ser dentro do mundo. Espontaneidade pura, a consciência não pode ser tomada como uma coisa, e nem se submeter à causalidade mecânica que constitui a interação entre os objetos cuja realidade foi restituída com o conceito de intencionalidade. Nos próximos capítulos, pretendo acompanhar como essa segunda parte do itinerário do jovem Sartre se cumpre.

No final dos anos 30, o trabalho de Sartre se volta para a psicologia, o resultado desse novo estudo, ainda influenciado pela fenomenologia, são os dois livros sobre a questão da imagem (A imaginação e $O$ imaginário, ou, apenas, os livros sobre a Imagem) e o Esboço para uma teoria das emoções (doravante Emoções, ou simplesmente E.). Esse novo interesse não é fortuito. A psicologia do final do século XIX e início do XX era uma ciência de forte influência positivista. Por essa razão, Sartre identifica uma tendência materialista inerente à metodologia psicológica da época. Tal metodologia pretendia espelhar-se nos procedimentos das ciências empíricas. Sendo assim, ela pressupunha a análise objetiva de fatos no intuito de desenvolver suas induções. Ora, o problema ao qual Sartre chama a atenção é que metodologia e objeto de estudo devem possuir compatibilidade entre si. Neste caso, há de se perguntar se o objeto da psicologia, ou seja, a consciência, aceita a abordagem objetivista. Em outras palavras, para o filósofo, um método de estudo só deve ser adotado uma vez que se conheça a natureza de seu objeto. Segundo ele, os psicólogos dessa época não tomaram tal precaução. Num ímpeto positivista, tais pesquisadores adotaram procedimentos de trabalho que tinham pouca afinidade com a natureza da consciência. Adotar um método a priori, é um procedimento fadado a resultar em conclusões equivocadas, pois o método já delimita e define seu próprio objeto antes de qualquer interpelação da realidade. Desse modo, no fim de seus estudos, os psicólogos estão condenados a encontrarem, apenas, as próprias premissas das quais partiram e, diga-se, eles próprios construíram. A psicologia objetivista nada descobre sobre a consciência, apenas coloca nela suas próprias crenças pré-estabelecidas. O detalhe é que tais crenças, como Sartre mostrará, têm sua origem em investigações alheias à psicologia, elas vêm de uma tradição metafísica sobre a constituição do mundo material. Portanto, a crítica do autor a essa ciência visa, em última instância, embasar sua crítica ao materialismo metafísico; é o itinerário dessa crítica que guia o estudo das imagens mentais e das emoções que será apresentado a seguir. 


\subsubsection{O ser em si e o ser para si}

O interesse pela ontologia, que perpassa o estudo da psicologia, já aparece na primeira página de $A$ imaginação. Lá, para apresentar a sua teoria sobre a imagem mental, Sartre familiariza o leitor com estes dois conceitos que formarão a principal dualidade existencial de sua grande obra de ontologia fenomenológica, esses conceitos opositores são o ser em si e o para si. Como veremos, a compreensão desses dois modos de existência constituirá o fundamento teórico que permitirá ao autor distinguir a imagem mental da impressão sensível. Nesse sentido, Sartre explicita a oposição ontológica entre a consciência e o mundo material que até então vinha sendo esboçada (e embasada) nas obras anteriores.

O que define a existência em si é a inércia própria do conteúdo sensível. Ele se apresenta como algo a ser desvelado, apreendido aos poucos; trata-se de uma passividade que se impõe como um limite à espontaneidade do meu ser. O ser em si é o ser das coisas cujos principais predicados são, portanto, inércia e desvelamento. Já o ser para si é definido como negação do em si, pois, para ele, existir e ter consciência da própria existência são uma só e mesma coisa. Portanto, trata-se de um ser que não se desvela e que é espontâneo (pois nada o coloca, ele mesmo se põe a existir); este é o ser da consciência.

Através dessa exposição, percebe-se a coerência em relação àquilo que já havia sido desenvolvido nas obras anteriores. Enquanto que os seres materiais se oferecem ao "olhar" da subjetividade por meio de uma infinidade de pontos de vista diferentes, que vão continuamente se somando ao conteúdo já apreendido, a consciência, ao contrário, se oferece por si e por inteira. Dada uma certa vivência, seu conteúdo está todo lá, não permite desvelamentos ulteriores a serem realizadas em ângulos diferentes. Em outras palavras, um objeto tridimensional pode ser sempre manipulado pelo sujeito observador, posso girá-lo, observá-lo de outro ângulo, ver hora uma, hora outra de suas faces, o mesmo vale para as qualidades que podem ser apreendidas pelos outros sentidos, como o olfato, paladar, etc. Já uma vivência da consciência se dá sempre por inteira, nunca haverá algo novo a ser descoberto nela. Além disso, o ser em si é um ser pleno, saturado; suas qualidades permanecem passivamente na existência. O ser para si da consciência, ao contrário, está sempre se colocando a si mesmo na existência, de maneira espontânea e não se oferece a nenhum olhar, senão o seu próprio, ou melhor, ele existe sendo o olhar 
de si mesmo. A consciência não possui qualidades inertes, pois não coincide consigo mesma, é sempre uma ação de só existir enquanto é consciente (de) si. Na medida em que é uma transcendência, para a consciência "a existência é esse movimento constante pelo qual o sujeito escapa disto que ele é, fazendo-se outro que si, não sendo aquilo que é na exata medida em que é aquilo que não é" (CABESTAN, 2015, p. 29). Como já foi considerado anteriormente, a consciência existe mais como uma ação, uma função de abertura fenomênica, e não como um ser mensurável, delimitável e definível, se por isso entendermos a dureza desta pedra.

Observando com atenção, nota-se que essa incipiente ontologia do ser das coisas em oposição ao nada da consciência que começa a ser esboçada aqui, além de explicitar algumas das teses desenvolvidas em $I$. e T. E., estabelece a distinção fundamental entre o modo de ser dos objetos materiais e o das ações da consciência. Tal distinção, por sua vez, irá embasar a crítica à psicologia objetivista, pois é através dela que se opera a diferenciação fundamental entre a impressão sensível e os estados fisiológicos, de um lado, e a imagem mental e as emoções, de outro.

\subsubsection{O método delimita o objeto}

Uma vez entendida a distinção apresentada no subcapítulo anterior, não é difícil prever que a principal acusação de Sartre contra uma psicologia que flerta em demasia com as ciências naturais será de que essa linha de pesquisa tende a confundir o modo de ser da consciência com aquele dos seres materiais. O resultado disso é uma concepção mecanizada do ser psíquico e a consequente reificação do ser humano. Mas, para que se compreenda o alcance dessa crítica, cumpre, antes, entender a maneira como ela foi apresentada pelo autor. Nesse sentido, o primeiro ponto a ser analisado é a exposição que o filósofo realiza da metodologia de toda uma corrente de psicólogos do final do século XIX e início do XX.

Tanto em a Imaginação, quanto no esboço das Emoções, Sartre dedica boa parte das obras para apresentar sua crítica a diversos teóricos e linhas de psicologia desse período citado. A acusação comum a todos os adversários é de que a psicologia desenvolvida por eles decorre numa concepção equivocada da consciência por conta da metodologia adotada. Trata-se de um problema na base de sua própria atividade, que 
determina a priori toda a série de resultados que serão obtidos. O nome dessa acusação é positivismo. Por positivismo, Sartre entende a tentativa de um fazer científico baseado na experiência a partir da observação objetiva de fatos. Aqui, fato significa um elemento inerte a ser encontrado, no decorrer da pesquisa um vai sempre se somando ao outro, de modo que sua coleção é sempre passível de enriquecimentos ulteriores. Ou seja, trata-se de um proceder metodológico que pretende se aproximar da metodologia das ciências naturais. O motivo desse flerte com as "ciências duras" seria um desejo de se aproximar da exatidão da qual elas gozam, tendência que, diga-se, existe até hoje, mas na época era ainda mais forte devido à influência da atmosfera positivista que envolvia diversas áreas do conhecimento e da sociedade.

Uma leitura atenta, principalmente de $A$ Imaginação, mostra que, para Sartre, essa tendência positivista se traduzia na psicologia através do método de análise e da experimentação objetiva. Tal método significaria estudar o objeto de conhecimento, objetivamente, a partir de sua decomposição em elementos simples, isolados, e, então, observar a relação de uns com os outros. Esta é uma metodologia que, de antemão, exclui qualquer recurso à introspecção, e busca encontrar os elementos fundamentais de seu objeto. Esse "atomismo" aplicado à consciência humana conduz a uma separação, um isolamento entre as vivências, transformando a consciência numa série de "fatos de consciência" que seriam os estados emocionais, as lembranças, as imagens, etc. Esses fatos, sem nenhuma relação intrínseca uns com os outros, e cada um com o todo da realidade humana, seriam convertidos nos "dados" puros tão caros à ciência natural, elementos que estariam submetidos às leis de inércia; tal qual a relação de movimento entre as bolas numa mesa de sinuca. Essa perspectiva cientificista pressupõe duas coisas. Primeiramente, podendo ser esses elementos dados isolados, nada em sua natureza se alteraria estando eles separados ou combinados entre si. Como os tijolos de um muro, ou as rodas de uma engrenagem que, apesar de quando em coletivo formarem um todo e uma dinâmica do todo, isoladamente permanecem iguais, estando nesse todo ou dele separados. Em segundo lugar, a relação entre eles é uma relação externa, daí a alusão sartreana ao princípio de inércia. Nessa acepção, isso significa que todas as forças que animam certo elemento isolado the são exteriores, os objetos reagem e transmitem tal força uns entre os outros, de forma mecânica, exatamente como as bolas na mesa de bilhar distribuem entre si a força exercida pelo taco; nenhum impulso parte das próprias esferas. Em uma palavra, esses elementos possuem uma dinâmica passiva, pois sua força motora 
vem de fora, eles nada produzem ativa e espontaneamente. Logo, caso fazer ciência signifique utilizar de tal procedimento de análise, então concebe-se, de antemão, que o objeto estudado é uma combinação de invariantes inertes. Mas, uma vez que a consciência, na concepção sartreana, é um todo sintético e espontâneo, por natureza averso às leis que regem o mundo material, já é possível perceber as consequências problemáticas nas quais esse método de estudo psicológico irá incorrer na opinião do filósofo; reificação e eliminação da subjetividade humana.

Essa crítica aos "fatos de consciência" pode ser inscrita na mesma trilha que as objeções à concepção espacial da consciência que foi descrita no primeiro capítulo desta dissertação. Da mesma forma que no artigo da Intencionalidade, cumpria combater a ideia de que a consciência seria um espaço e as representações, seus conteúdos, aqui Sartre pretende recusar a ideia de que as vivências psíquicas possam ser tomadas isoladamente, de modo que a consciência seria apenas o lugar onde se guardaria uma coleção interminável de lembranças, imagens, emoções, percepções, etc. Diferentemente de uma caixa onde se depositam bolinhas de gude, - que, rolando, chocam-se umas com as outras, transferindo uma força exterior - a consciência, para Sartre, tem o aspecto das águas de um lago; um sistema fluido, contínuo, no qual a menor perturbação feita em uma borda, geraria ondulações até a outra margem. Há uma lógica interna entre as vivências da consciência, que faz com que cada um de seus atos expresse os demais e o todo do qual faz parte. Em A Imaginação, essa coerência interna é chamada de espontaneidade sistematizadora, ao passo que no esboço das Emoções, é a essência humana que se expressa em e por cada um dos atos da consciência. Esses dois termos, cada um à sua maneira, significam igualmente a absurdidade de se estudar a consciência de maneira fracionada, numa divisão e atomização que perverteriam sua própria natureza. Por essa razão, há uma crítica à metodologia psicológica nos dois ensaios que estão sendo citados, e o principal ponto em comum da abordagem nas duas obras é o ataque à concepção de fato de consciência; em $A$ Imaginação porque essa noção embasa o método de análise, e em Emoções porque justifica a abordagem objetivista (consequentemente, a exclusão da subjetividade). Em ambas as obras o resultado da busca por fatos é o mesmo; a descoberta de uma coleção de elementos heteróclitos que jamais poderiam oferecer um conhecimento relevante sobre a subjetividade humana, mas apenas informações isoladas sobre temas que não se relacionam. 
Esperar pelo fato é, por definição, esperar o isolado, é preferir, por positivismo, o acidente ao essencial, o contingente ao necessário, a desordem à ordem (...) Os psicólogos não se dão conta, com efeito, de que é tão impossível atingir a essência amontoando os acidentes quanto chegar à unidade acrescentando indefinidamente algarismos à direita de 0,99. (SARTRE, 1975, p. 9-10)

Conduzida dessa maneira, a psicologia decairia num mero trabalho curioso de colecionador, pois nada diria sobre o que é o ser humano.

Em A Imaginação, essa crítica é principalmente observada na apresentação que o autor realiza da teoria de Taine ${ }^{48}$, não por acaso, um dos expoentes do positivismo francês. Segundo Sartre, esse autor representaria o psicologismo de sua época, pois quando adota de antemão o método de análise da consciência, ele já parte do pressuposto de que a complexidade psíquica possa ser reduzida a um mecanismo, cujas partes e elementos seguiriam a mesma dinâmica de engrenagens materiais. Como percebe Moutinho (1995, p.81-82), o procedimento tainiano é composto por três passos consecutivos; primeiramente se coisifica o psíquico, identificando o seu modo de ser com o da sensação. Em seguida, esse psíquico convertido em coisa é decomposto em seus elementos mais simples, diferentes em aspecto, mas iguais em natureza, eis que surgem os fatos de consciência. Por fim, restaria determinar a relação entre essas partes recortadas da consciência que, uma vez que foi coisificada, seria um ser inerte, incapaz de organizar seus elementos através de um princípio interno, necessitando, assim, de algo externo para explicar sua dinâmica. Daí percebe-se que Taine não conclui, mas pressupõe que as vivências psíquicas possam ser tidas como fatos de consciência. Portanto, a psicologia de análise não encontra a posteriori uma natureza mecanizada da consciência, ao contrário, já parte do princípio, a priori, de que a consciência é mecânica.

Assim, para os intelectuais da época que consideramos (final do século XIX), tomar uma atitude científica diante de um objeto qualquer - seja ele um corpo físico, um organismo ou um fato de consciência - é estabelecer, antes de toda investigação, que este objeto é uma combinação de invariantes inertes que mantém entre si relações externas (SARTRE, 1965, p. 22-23).

\footnotetext{
${ }^{48}$ A principal obra de Hyppolite Taine a qual Sartre faz alusão é a De l'intelligence (1870). De resto, a reconstituição da obra desse autor é bastante econômica.
} 
Em outras palavras, a análise não revela um psíquico coisificado, mas para que se faça a análise o psíquico já deve ter sido transformado numa coisa, e isso é feito identificando o seu modo de ser com o da sensação. Portanto, a mecanização da consciência nunca é concluída, mas pressuposta. Isso é o que decorre dessa atitude positivista de estudar psicologia a partir de um suposto cientificismo; o método adotado não permite descobrir a verdadeira natureza do objeto, pelo contrário, a delimita de antemão. O resultado já se encontrava no próprio princípio do qual se partiu.

Esse problema de método não se resume apenas à atitude de análise, na verdade, a análise, por sua vez, pressupõe uma tendência que lhe é anterior; o associacionismo. Em A Imaginação, Sartre mostrará que o cientificismo positivista não se manifesta apenas no mecanicismo clássico que a análise propõe, mas em outras tendências que, embora tentem recuperar hora um vitalismo, hora uma síntese da consciência, ainda assim, não conseguem se livrar de algo em comum com a análise, a presença de leis associacionistas na consciência, o que, por sua vez, implica na assunção de que elementos na consciência se comportam de forma passiva e, diga-se, material.

O associacionismo surge para Taine quando, após reduzir a consciência aos seus elementos mais simples, isolando esses supostos fatos, esse autor se questiona como tais elementos se relacionariam entre si. Segundo Sartre, é no associacionismo que o psicólogo encontra sua resposta. Pois, uma vez que essa configuração da consciência pressupõe um conjunto de elementos inertes, então, na falta de uma espontaneidade sistematizadora interna aos elementos - ou seja, um princípio organizador imanente, apenas as leis mecânicas da associação poderiam explicar sua organização. Não é de outro modo que o filósofo entende essas leis; a ligação mecânica e exterior entre elementos psíquicos que traduziria, em psicologia, o que é a lei de inércia para a física.

No entanto, esse se trata de um associacionismo vulgarizado em relação ao de Hume, por exemplo. Pois, enquanto o filósofo empirista se limitava ao campo psicológico, Taine, por sua vez, aplica as leis de associação para fazer uma ponte confusa entre o psicológico e o fisiológico. Isso acontece, pois sua teoria identifica o resultado da análise - os fatos de consciência - unicamente com a sensação.

Não há nada de real no eu salvo a fila de seus acontecimentos. Esses acontecimentos, diversos em aspecto, são os mesmos em natureza e resumemse todos à sensação; a própria sensação, considerada de fora e pelo meio 
indireto que chamamos de percepção exterior, reduz-se a um grupo de movimentos moleculares. (TAINE, 1870, apud SARTRE, 1965, p.25).

Segundo essa concepção, as únicas coisas na consciência que não seriam a sensação pura, seriam suas repetições; eis o caso das imagens mentais. Sendo assim, uma vez analisada, não haveria outra coisa na consciência senão sensações e repetições menos vívidas dessas mesmas sensações na forma de imagens. Essas imagens, por sua vez, se combinariam segundo as leis da associação para formarem as demais modalidades do pensamento. "Tudo o que, no espírito, ultrapassa 'a sensação bruta' resume-se a imagens, isto é, a repetições espontâneas da sensação" (TAINE, Ibidem, p. 25).

Sartre ainda ressalta que, antes de fazer uso da experiência, Taine parte de uma definição arbitrária sobre o que seria a experiência, uma vez que confunde ingenuamente experiência com análise.

“A confusão inicial de Taine entre a experiência e a análise leva-o a constituir um associacionismo híbrido que ora se exprime em linguagem fisiológica, ora em linguagem psicológica, ora nas duas línguas ao mesmo tempo; seu empirismo puramente teórico é acompanhado de um realismo metafísico" (SARTRE, 1965, p.26).

Por essa razão, sem perceber, esse psicólogo, ao explicar o funcionamento da consciência, passa placidamente do plano psicológico para o fisiológico. As leis que regem o funcionamento da consciência seriam mecânicas, pois a própria consciência não seria mais do que uma derivação da sensação e, em última instância, de "movimentos moleculares". Não é por acaso que, no final da citação acima, Sartre menciona o realismo metafísico. Em Taine, encontra-se uma teoria que, antes de se debruçar sobre seu objeto, parte de um pressuposto não fundamentado sobre o que seria a experiência e o método para o estudo desse mesmo objeto. $\mathrm{O}$ objeto é obrigado a responder apenas àquilo que $\mathrm{o}$ método sabe perguntar. Uma vez que esse método é buscado no modelo das ciências naturais, o objeto será, por fim, moldado de forma naturalizada ${ }^{49}$. Portanto, numa tal perspectiva, a consciência não seria outra coisa senão um conjunto de sensações e sensações renascentes que se comportam segundo as leis associacionistas.

\footnotetext{
49 “(...) a opção prévia pela análise implicará uma deturpação do psíquico. A ambição aqui é a cientificidade da psicologia, razão pela qual as ciências naturais aparecem como modelo, condicionando metodologicamente a psicologia positivista" (MOUTINHO, 1995b, p. 81).
} 
No Esboço para uma teoria das Emoções, há uma continuidade dessa crítica à metodologia reificante. Aqui, também, o anseio positivista por fatos - que só podem ser obtidos através da experiência objetiva - resulta na exclusão da subjetividade. Como já foi dito, os fatos podem se acrescentar indefinidamente uns aos outros, de modo que possuem uma relação meramente quantitativa entre si. O que significa que um fato nada significa, ele apenas é. Em A Imaginação, o resultado da busca por fatos era a decomposição da consciência em elementos isolados que jamais poderiam se reagrupar numa totalidade sintética. Agora, indo mais além, Sartre afirmará que tal busca resulta numa ciência infrutífera, pois apenas oferece uma coleção de elementos heteróclitos. Sendo assim, a psicologia objetivista jamais poderia oferecer algum conhecimento sobre a realidade humana, ou flertar com a antropologia, tratar-se-ia, tão somente, de um mero trabalho de colecionador de fatos sobre o psíquico.

Como Taine o foi em A Imaginação, W. James é no esboço das Emoções o autor selecionado por Sartre para encarnar a versão mais radical da teoria que pretende combater e, ao mesmo tempo, mais expressa o malogro da psicologia positivista. No estudo das emoções, o método positivo é traduzido pela abordagem exclusivamente objetiva dessas manifestações psíquicas. Ora, a emoção observável, para um cientista externo ao sujeito emocionado, se expressa apenas de duas maneiras; através das condutas e das alterações fisiológicas. Desse modo, o método objetivista delimita a emoção nesse campo observável, eliminando qualquer recurso à subjetividade que vive, que experiencia tal emoção. Uma vez feita tal delimitação, a busca pela cientificidade psicológica não demora para, em seguida, reduzir e identificar a emoção com essas manifestações externas. E não haveria elemento melhor que o fisiológico para cumprir as exigências da abordagem positiva, já que as alterações corporais que acometem a pessoa emocionada são perfeitamente mensuráveis e quantificáveis. É daí que surge a teoria periférica das emoções, representada pela figura de James.

$\mathrm{Na}$ teoria periférica, as emoções seriam apenas a projeção dos distúrbios fisiológicos na consciência ${ }^{50}$. Segundo Sartre, trata-se da tese que supõe que uma mulher não chora por estar triste, ao contrário, está triste porque chora. Contra essa teoria, o autor argumenta que a alterações quantitativas no corpo, não podem corresponder expressões

\footnotetext{
50 “A emoção assim descrita (James) é separada do sujeito que a vive: ela é objetivada, cortada da consciência e tomada apenas como realidade física (mudanças corporais) como se fosse um evento da natureza." (MOUTINHO, 1995a, p. 54)
} 
qualitativas na consciência. Pois, emoções diferenciadas como a alegria e a cólera são irredutíveis entre si, apesar de seus correspondentes fisiológicos - aceleração do ritmo respiratório, ligeiro aumento do tônus muscular, crescimento das trocas bioquímicas e da tensão arterial - variarem apenas em intensidade. Não é preciso muito para mostrar como a diferença de grau dessas alterações não pode se reapresentar em emoções tão distintas na consciência, pois está claro que um homem em cólera não está superalegre. Enfim, a referência feita a James serve para mostrar, mais uma vez, como a adoção de um método a priori (no caso, a experiência objetiva) condiciona o objeto. O estudo positivo das emoções está fadado a uma naturalização tal da consciência que exclui completamente a subjetividade, uma vez que substitui a vivência psíquica pelo distúrbio fisiológico. A implicação mecanicista dessa teoria é clara, e os demais psicólogos apresentados no tratado das Emoções permanecerão sempre, em maior ou menor medida, presos a esse tipo de abordagem reificante devido à herança positivista.

A partir desta exposição, percebe-se que a crítica de Sartre incide, primeiramente, na metodologia da psicologia de sua época. É por conta da metodologia adotada que esses psicólogos assumem uma concepção materialista da consciência, e não por causa do resultado de seus estudos. Por sua vez, essa metodologia é adotada a fim de seguir uma tendência positivista, trata-se de uma escolha arbitrária de adotar como único critério de cientificidade estudos que possam apresentar exatidão e mensurabilidade, nos moldes das ciências da natureza. Em psicologia, esse projeto se traduz na dinâmica associacionista que pressupõe que a consciência é composta por ou tem como base os dados da sensibilidade - que esses psicólogos, expostos por Sartre, têm tanta dificuldade em abandonar. Um dos motivos pelos quais a imagem mental é um tema tão importante para o jovem Sartre é esse; a concepção da imagem herdada da tradição metafísica moderna e trabalhada pela psicologia positivista - é uma concepção material, portanto, afirma a presença de conteúdos na consciência. Para Sartre, a dinâmica associacionista desses supostos entes materiais interagindo na consciência implica numa mecanização inaceitável da subjetividade. O estudo das emoções seguirá essa mesma linha de recusar uma interpretação da vida psíquica que exclua a subjetividade, substituindo-a pelo mecanismo fisiológico. As obras de psicologia fenomenológica cumprem coerentemente seu papel no programa sartreano de afirmar a soberania da consciência, o que, posteriormente, significará instituir as bases da ética existencialista da liberdade inerente à realidade humana, já que, como será mostrado no próximo capítulo, a liberdade da 
consciência é uma implicação de sua indeterminação ontológica. De acordo com Franklin Leopoldo e Silva (2013, p.13) "Indeterminação quer dizer liberdade. (...) É a pura e simples indeterminação da existência que nos leva a considera-la livre. A liberdade não se acrescenta ao sujeito porque se identifica com sua realidade ontologicamente". Por essa razão, não basta combater apenas as ideias de imagem e emoção coisificadas e, com isso, expulsar mais um conteúdo da imanência transcendental como havia sido feito com o Eu em T. E., agora trata-se de combater toda uma psicologia de coisas ${ }^{51}$ para assegurar uma concepção não reificada do ser psíquico que o filósofo quer constituir nessas obras do final dos anos 30 .

\subsubsection{A psicologia de coisas}

Como foi indicado, a opção pelo estudo dos fatos, a partir da experiência objetiva, significa a exclusão da subjetividade na psicologia. Uma vez ausente a subjetividade, toda a vida psíquica seria regida por um mecanismo, seja na relação associacionista entre as imagens de reminiscência material, seja na dinâmica causal da emoção tida como distúrbio fisiológico. Portanto, para preservar a concepção de consciência, conforme descrita pela fenomenologia, Sartre deve reconstruir toda a noção de psíquico constituída por essa psicologia positiva. Para tal, o autor primeiramente expõe toda essa linha psicológica, representada na figura de alguns de seus principais teóricos, para assim demonstrar suas insuficiências.

Em $A$ imaginação, Taine representa a tese mecanicista mais clássica dentre os psicólogos que Sartre combate, mas não a única, pois, segundo o filósofo, mesmo outros psicólogos que tentam se impor contra o espírito de análise e o mecanicismo puro, nunca se distanciam tanto de Taine. A causa disso é a dificuldade desses psicólogos abandonarem o associacionismo e sua maneira mecânica de interpretar a dinâmica da consciência. Por sua vez, essa insistência no associacionismo é resultado da concepção a

\footnotetext{
51 "Não é difícil perceber que o combate à imagem-coisa se imporá da mesma forma que, no Ensaio sobre a transcendência do ego, combateram-se os conteúdos de consciência. Dessa vez, contudo, a crítica se desdobra em outro plano: não se trata apenas de purificar o campo transcendental da presença de conteúdos, mas ainda de se discutir a natureza mesma do psíquico, repropondo assim uma nova psicologia." (MOUTINHO, 1995b, p. 78)
} 
priori que se tem da imagem mental como uma revivescência da sensação. A seguir, continuarei acompanhando a crítica sartreana contra alguns desses psicólogos.

Ribot é citado ${ }^{52}$ como um psicólogo que, inicialmente, tenta reconsiderar os direitos da síntese na psicologia. Esse autor consideraria a ciência como uma atividade de análise, mas também de síntese, isso pelo fato de que na própria natureza haveriam sínteses; um exemplo disso é a dinâmica biológica. No entanto, Sartre salienta que a proposta de Ribot não o afasta tanto de Taine, já que os resultados da pesquisa de ambos são os mesmos; uma tese coisista da consciência. Isso ocorre, pois, a síntese de que fala Ribot - uma vez que este se apoia na dinâmica biológica para explicar a consciência vem inteiramente de um modelo fisiológico. Aqui, a consciência seria apenas um produto evolutivo destinado a se aplicar às formas primárias do conhecimento: sensações, memória, associação. Segundo Sartre, essa tese incorre na impossibilidade de se considerar um pensamento puro, uma vez que a atividade da consciência só seria uma função misteriosamente aplicada a essas formas primárias originadas da materialidade sensível. O filósofo evidencia isso na exposição da forma como Ribot entendia as imagens mentais. Em A imaginação criadora, o psicólogo delimita o poder criador da imaginação a uma atividade de dissociação e associação realizada, de modo inconsciente, sobre as imagens que, assim como em Taine, se originariam da impressão sensível. Essa atividade que Sartre chama de "associacionismo dirigido" também seguiria razões evolutivas. Portanto, estamos diante de uma ação que não visa a nenhum fim, mas apenas decorre de causalidades naturalistas ${ }^{53}$.

Por conta dessa inspiração biologicista no que concerna à natureza da consciência, Sartre ainda argumenta que Ribot chega a "negar resultados experimentais em nome de deduções puras" (SARTRE, 1965, p. 37), devido a essa posição de que os dados primários da introspecção seriam sensações. Por sua vez, isso implica na impossibilidade a priori de um pensamento puro; daí o pensamento ser uma atividade inconsciente que viria a se aplicar sobre os dados da sensação. Mais uma vez, na tentativa de elaborar uma psicologia científica, concepções preestabelecidas determinam a natureza da consciência a despeito de qualquer experiência que se faça sobre tal objeto. Para Sartre, a noção biológica de

\footnotetext{
52 (SARTRE, 1965, p. 35)

${ }^{53}$ A questão da finalidade dos atos de consciência é de suma importância para Sartre. No próximo capítulo, mostrarei que no Esboço para uma teoria das emoções é a finalidade da conduta emocional que permite assegurar a espontaneidade e o caráter organizado da consciência.
} 
pensamento inconsciente, produto evolutivo, inscreve Ribot nessa geração associacionista para quem “o pensamento será apenas uma hipótese necessária para explicar uma 'organização"” (Idem, ibidem.), sendo essa organização apenas o resultado das relações associacionistas entre as imagens sensíveis.

Portanto, a psicologia de Ribot também é coisista, pois a característica de síntese que esse psicólogo tentou incluir em seus estudos é inteiramente constituída pela dinâmica fisiológica. Desse modo, as imagens mentais estariam para a consciência como os alimentos para o sistema digestivo; é apenas nesse sentido de todo funcional que o psicólogo fala em síntese. Sartre conclui que se a atividade psíquica de síntese funcionasse como uma função biológica, então tratar-se-ia, aqui, de um processo determinista cujos elementos são todos, igualmente, coisas; o ser humano, as imagens mentais e o pensamento. Em suma, do mesmo modo que Taine estabelece sua psicologia a partir do modelo da física, Ribot o faz a partir da biologia. A presunção cientificista de ambos os conduz a uma teoria, igualmente, reificada da consciência.

Outra linha psicológica abordada por Sartre em $A$ imaginação é a da escola de Würzburg que, desenvolvida no início do século XX, representaria a atitude cartesiana frente às imagens. Para o filósofo, esses psicólogos - principalmente representados por Binet - apresentariam alguns avanços em relação aos anteriormente citados, pois eles, influenciados pelas Investigações Lógicas de Husserl, buscavam atestar a existência de um pensamento puro, sem intermediários sensíveis. Sartre não chega a explicar como funcionariam as experiências realizada pelos representantes dessa escola, mas afirma que através de um método chamado de "introspecção experimental" (cujos resultados seriam garantidos pelo cogito cartesiano), eles teriam encontrado esse tipo de pensamento independente de qualquer raiz sensível. No entanto, o autor também fará ressalvas em relação a esses psicólogos, pois eles também acreditavam que as imagens mentais eram seres nascidos da sensibilidade. Sendo assim, numa atitude tipicamente cartesiana, a escola de Würzburg separa e opõe esse pensamento puro às imagens sensíveis. Nesse caso, a imagem, por conta de seu vínculo com a percepção, seria apenas um estorvo para o pensamento. Trata-se, aqui, da mesma distinção entre a substância pensante e as impressões fornecidas pelo pedaço de cera da meditação de Descartes; apenas o entendimento, e não os dados imagéticos da percepção, pode fornecer o conhecimento verdadeiro de tal objeto. Uma vez que as imagens mentais sejam consideradas dessa forma, então elas são um intruso material na consciência. Segundo Sartre, esse problema 
também é consequência do preconceito associacionista de conceber a imagem como um suporte material do pensamento, e não ele próprio sob outra forma (como é a tese do filósofo que será exposta mais à frente). Portanto, eis mais uma teoria que não se distancia tanto de Taine.

Em síntese, o problema comum de toda a psicologia da imagem do final do século XIX é tomar a imagem como uma reminiscência material no pensamento, uma revivescência da percepção, portanto, uma coisa. Essa concepção é um pressuposto herdado, acriticamente, da tradição metafísica moderna. Da mesma forma que durante séculos os astrônomos se debateram com fórmulas complicadas para descrever o movimento dos astros a partir de círculos perfeitos em volta da Terra, - apenas porque se pressupunha que o céu era um reino de perfeição e, portanto, deveria se mover segundo a forma perfeita do círculo, os psicólogos, pressupondo que a imagem se originaria na sensação, tiveram que elaborar teorias problemáticas para explicar a relação desse ente supostamente material com o espírito. No início do século XX essas dificuldades continuaram. O desafio consiste em aproximar a imagem sensível com o domínio do pensamento. De maneira geral, a psicologia concebia a imagem como algo elaborado pelo pensamento, mas tal elaboração seria entendida, tão somente, como um processo de fragmentação e recomposição. Em Meyerson, por exemplo, a imagem serve como signo de algum objeto sensível, e caberia ao pensamento compreender tal significação. Entretanto, uma vez que tais termos se referem a elementos materiais, o caráter mecanicista dessa tentativa de aproximação continua tão latente quanto nas teses associacionistas do final do XIX. Trata-se de uma tentativa malograda de fundir a imagem (pontual e delimitada) na continuidade do pensamento; um bloco sólido imerso num rio, obstruindo sua fluidez.

Da mesma forma que os psicólogos que se dedicaram ao estudo das imagens mentais não conseguiram se afastar de Taine, também os psicólogos que se debruçaram sobre a emoção, não conseguiram se afastar do teor mecânico instituído por W. James ${ }^{54}$. Segundo Sartre, Janet teria compreendido ${ }^{55}$ a principal insuficiência da teoria de James, que seria o fato de um distúrbio físiológico não poder explicar o caráter organizado da

\footnotetext{
${ }^{54}$ A teoria periférica comentada na seção anterior.

55 (SARTRE, 1975, p. 14).
} 
emoção. Por essa razão, Janet tentou reintroduzir o psíquico na explicação da emoção, para conferir a ordem que a mera alteração corporal não poderia fornecer.

No entanto, Sartre afirma que Janet falha nesse intento. Esse malogro, como é de se esperar, já se enuncia pela metodologia objetivista que o psicólogo adota. Pois, munido de tal método, ele só tem acesso às manifestações orgânicas que se dividiriam em duas categorias; de um lado os fenômenos psíquicos que ele chama de condutas, do outro os fenômenos fisiológicos. Sartre concorda que a única maneira de restituir o psíquico na emoção seria fazendo dela uma conduta. Porém, a única conduta que Janet interpreta nos fenômenos emotivos é a conduta de fracasso, uma conduta desadaptada ou insuficiente em relação ao que determinada situação exigiria. Essa interpretação já denota a dificuldade de se afastar em definitivo da concepção de que o ato emocional seria uma desordem frente a uma conduta superior.

Um dos exemplos reproduzidos por Sartre dessa conduta de fracasso é o da paciente que ia até o consultório de Janet para fazer alguma confissão, mas que, entretanto, caia em crises nervosas e chorava antes de realizar a tarefa almejada. Nesse caso aconteceria que, uma vez que a ação exigida era social e psicologicamente muito difícil de se realizar (dada a posição de respeito de Janet, a pressão moral, etc.), então a paciente, para se livrar do tensionamento psíquico, caia em prantos, transformando Janet de juiz severo a consolador. Para Sartre, este poderia ser um exemplo autêntico de conduta, caso tivesse sido estrategicamente adotado pelo psíquico da paciente. Entretanto, há uma diferença entre chorar por não conseguir dizer nada, e chorar para nada dizer. Claramente, a primeira postura se dá de modo automático enquanto que a segunda seria verdadeiramente uma conduta. Como se antevê, Janet interpreta o caso a partir da primeira forma. Isso ocorre por conta de sua interpretação de que a emoção é um malogro frente à conduta superior que deve ser adotada (a confissão). Essa concepção unívoca da emoção, como um fracasso frente à conduta superior, trata-se, na verdade, de uma tese mecânica, pois a emoção corresponderia apenas a uma descarga automática da energia psíquica para a situação de menor exigência psicológica, tal qual a corrente elétrica corre, naturalmente, pelo caminho de menor resistência. $O$ fracasso seria, simplesmente, uma derivação automática da conduta superior. Ou seja, aqui não se trata, qualitativamente falando, de um fracasso, mas de um movimento automático. Pois, para que o fracasso seja vivenciado como tal, é preciso que a conduta em questão receba essa significação de fracasso. Isso só pode ser realizado pelo poder constituinte da consciência. Caso contrário, 
a suposta conduta permaneceria uma reação orgânica difusa, "uma simples descarga de energia nervosa segundo a lei do menor esforço" (SARTRE, 1975, p. 25) e, segundo Sartre, é essa a interpretação de Janet, além de que o psicólogo só utiliza exemplos de emoções pouco qualificadas e diferenciadas, que se caracterizam mais como perturbações próximas do choque emocional nervoso do que como sentimentos definidos. No modo como está construída, essa teoria está fadada a ser mais uma interpretação mecanicista da consciência.

\footnotetext{
Para Sartre, também essa teoria (de Janet) objetiva o fato psíquico. E o faz porque para ela a derivação de uma conduta por outra se dá automaticamente, na medida em que a substituição se dá conforme a tensão psicológica: é uma relação entre coisas. Não há aqui intervenção do sujeito. $\mathrm{O}$ indivíduo é compreendido como um sistema objetivo de condutas, que reage conforme a energia nervosa acumulada, descarregada automaticamente. Tratase, pois de uma teoria mecânica que, no fundo, em nada se diferencia da teoria de James. (MOUTINHO, 1995a, p.55)
}

O que falta para que a emoção descrita por Janet seja de fato uma conduta (de fracasso ou qualquer que seja) é a finalidade na ação do psíquico que se emociona, pois a finalidade atestaria a emoção como um sistema organizado de meios que visam fins. Além disso, a finalidade pode explicar a diversidade e diferenciação entre as emoções, uma vez que situações de pressão psíquica diferentes exigiriam que a consciência elaborasse diferentes condutas para resolver cada impasse. Segundo Sartre, essa finalidade já se encontra subjacente na teoria do psicólogo, pois é o que sugere o termo "conduta" de fracasso. No entanto, a interpretação do choro da paciente como fato decorrente dela nada poder dizer, no lugar de uma ação para nada dizer - que forneceria inteligibilidade para a razão da conduta - evidencia a dificuldade de se afastar de uma leitura mecânica da consciência. Daí a visão de que a emoção seria uma descarga de energia psíquica. Ainda estamos diante das dificuldades suscitadas pela metodologia positivista. "Mas Janet nos deu o que podia: ele é demasiado incerto, dividido entre um finalismo espontâneo e um mecanicismo de princípio" (SARTRE, 1975, p. 27-28). Portanto, seja a emoção entendida como uma perturbação fisiológica (James) ou uma descarga de energia psíquica (Janet), o princípio mecânico permanece o mesmo; ainda estamos diante de uma psicologia de coisas.

Antes de encerrar esta seção, acredito ser frutífero abrir um parêntese para expor o curto comentário sobre a psicologia psicanalítica desenvolvida no meio do Esboço das Emoções. À primeira vista, o debate com a psicanálise pode parecer lateral no contexto 
da crítica às teorias psicológicas materialistas, mas pretendo mostrar que esse comentário adianta consequências importantes do caráter irrefletido da consciência.

Sartre inicia seu debate com a teoria psicanalítica, reconhecendo que ela foi a primeira a acentuar a significação dos fatos psíquicos, ou seja, que todo estado de consciência remete à outra coisa que não si próprio. Nisso, há acordo entre a psicanálise e a posição sartreana. O problema com a teoria psicanalítica é o princípio do qual partem suas explicações. Segundo Sartre, ela concebe o fenômeno consciente como a realização simbólica de algum desejo recalcado - majoritariamente de origem sexual. Para o filósofo, o problema é que, nessa concepção, a consciência não percebe a implicação desse desejo em sua própria realização simbólica. "Disso resulta que a significação de nosso comportamento consciente é inteiramente exterior a esse próprio comportamento (...) o significado é inteiramente separado do significante" (Idem, p. 35). Sendo assim, a teoria psicanalítica interpreta a relação entre a consciência que constitui a significação (que, no caso, será chamada de inconsciente) e a consciência emotiva, como uma relação de exterioridade e, mais ainda, como se a segunda fosse um efeito passivo da primeira, ou seja; uma coisa.

Para ilustrar essa estranha relação entre duas consciências no jogo simbólico, Sartre faz um paralelo com a relação entre os vestígios de uma fogueira nas montanhas e a maneira como ela indica a presença de seres humanos. Nesse exemplo, tem-se uma relação completamente externa, a fogueira apagada apenas indica que pessoas estiveram no local, mas de modo algum contém essas pessoas e sua intenção de se aquecer. Ou seja, assim como a madeira queimada é uma coisa passiva, um efeito da presença de pessoas com frio - que com elas não guarda nenhuma relação sintética, para a teoria psicanalítica descrita por Sartre, um fato de consciência seria uma coisa em relação a seu significado (o desejo recalcado). Assim, o surto de uma jovem que come azeitonas é um efeito passivo e exterior em relação a um episódio de violência sexual sofrido num olival.

Já é possível antever uma das objeções de Sartre em relação a essa teoria. Ora, sendo a consciência uma totalidade sintética, ela não pode estar apartada da significação que ela mesma constituiu. Além disso, o fato de a significação não estar totalmente implícita numa conduta emocional, não implica que ela seja inconsciente. Ocorre apenas que existem diferentes "graus de condensação e de clareza" (Id. p.36). Ou seja, uma consciência irrefletida, não tética de si, pode realizar distraidamente os seus atos, como 
quando escrevo estas palavras e não presto atenção em cada tecla clicada no computador, nem por isso pode-se dizer que estou inconsciente do meu ato de digitar no teclado só porque o objeto noemático de minha consciência seja o aparecimento de cada palavra como uma exigência objetiva, e não a ação mesma de apertar cada tecla. Irreflexão não significa, em absoluto, inconsciência. Em resumo, o filósofo reconhece que a teoria psicanalítica acerta ao atribuir o caráter de símbolo do fato consciente em relação ao complexo que exprime. No entanto, o processo de simbolização é interpretado pelo psicanalista como uma relação causal entre um fato transcendente (o desejo recalcado) e o fato de consciência que seria constituído como símbolo. É por conta dessa interpretação - causal, praticamente mecanicista - que a teoria psicanalítica tende a criar um sistema engessado de explicações ${ }^{56}$. Esse é o resultado de apartar a consciência de sua espontaneidade, de seu poder de constituir e viver suas próprias modificações. Pelo fato de a significação psicanalítica vir de fora, essa teoria precisa recorrer ao inconsciente que, na prática, é tão somente uma duplicação do sujeito; o inconsciente torna-se um sujeito oculto que age de fato, e a consciência seria um sujeito passivo, seguindo mecanicamente os impulsos do primeiro. O recurso a esse inconsciente, para Sartre, significa apenas atrasar o problema, restando ainda por ser explicado o poder de constituição de significado desse sujeito oculto. A solução fenomenológica, como já se pode antever, será unificar essa relação entre constituir e viver a significação numa só e mesma consciência, num todo sintético cujo poder de criação de sentido decorre de sua liberdade espontânea.

Essa curta crítica à psicanálise possui algumas ressalvas. A teoria reproduzida na obra sartreana não faz menção a nenhum teórico específico, parecendo ser uma interpretação generalizada de certos princípios freudianos. O próprio Sartre reserva suas críticas para o psicanalista teórico enquanto reconhece o potencial de acertos que o psicanalista clínico pode alcançar, uma vez que no processo de análise ele busca a "compreensão" do processo de simbolização, pois apenas a compreensão preserva a ligação de continuidade entre significado e significante, ou seja, a própria consciência se constituindo na forma de simbolização. Ainda assim, a reconstituição dessa crítica cumpre o papel importante de mostrar que até mesmo uma teoria que reconhece o papel funcional e simbólico da emoção, pode cair na mesma tendência mecanicista das teorias

\footnotetext{
56 “(...) uma pregadeira de alfinetes significa sempre, no sonho, seios de mulher, entrar num vagão significa fazer o ato sexual (...)" (SARTRE, 1975, p. 37). Assim, criar-se-ia um catálogo fixo para relacionar símbolos e significados (objetos pontiagudos sempre são falos); eis aberto um perigoso caminho para uma psicanálise vulgarizada e simplista.
} 
psicológicas anteriormente criticadas, fazendo da consciência uma coisa que não possui nenhuma autonomia em relação às suas vivências afetivas. Essa perigosa tendência reificante mostra os perigos de uma interpretação que não compreende a verdadeira natureza da espontaneidade da consciência irrefletida.

Portanto, nas duas obras sobre psicologia fenomenológica, é possível perceber que mesmo tratando de temas diferentes (imaginação ou emoção) Sartre realiza uma mesma crítica contra toda psicologia de linhagem positivista; trata-se de uma ciência reificante. Não era possível esperar outra coisa de uma abordagem psicológica que cinde a consciência em elementos isolados e estuda seus fenômenos de forma heteróclita, tentando constituir leis gerais. Esses problemas decorrentes da experiência psicológica indutiva - que une a crítica sartreana nos dois textos - estão na mesma esteira de todo materialismo metafísico que vê a realidade física como a única forma de existência, suprimindo assim a subjetividade humana. É contra essa concepção materialista que a filosofia de Sartre se coloca, agora, com o mesmo fervor com o qual outrora havia combatido o idealismo de Brunschvicg. Para responder à psicologia de coisas, resguardando a espontaneidade da consciência, o filósofo elabora sua concepção fenomenológica de imagem e emoção que apresentarei a seguir.

\subsection{A intencionalidade da imagem e da emoção.}

\footnotetext{
Eu creio, amigo, que a existência inteira. É um mistério talvez; - mas n'alma sinto. Sentindo as brisas, recordando aromas (...) Que essas tardes e brisas, esse mundo. Que na fronte do moço entorna flores. Que harmonias embebem-lhe no seio - Têm uma alma também que vive e sente..." (Álvarez de Azevedo, "Panteísmo" In Lira dos vinte anos)
}

Sartre utilizará novamente o conceito de intencionalidade para combater os dualismos que pretende superar. Vejamos o problema da imagem mental, por exemplo. Para resolver essa questão sem ter que apelar para a reminiscência sensível, o filósofo propõe uma concepção fenomenológica da imagem que ele credita ao livro de Ideias I: "Tanto quanto a filosofia, esse livro estava destinado a revolucionar a psicologia" (SARTRE, 1965, p.139). A revolução que a obra de Husserl pode suscitar se deve, justamente, à concepção renovada da imagem que ela contém. É verdade que aqui, como em outros casos, é uma interpretação propriamente sartreana que iremos encontrar nesta leitura de Ideias I. Mas, dessa vez, Sartre explicita que Husserl apenas introduz o tema da 
imagem que ele próprio irá desenvolver, pois aqui já não concorda integralmente com o antigo mestre.

Mas qual é, afinal, essa nova concepção de imagem capaz de superar aquela perspectiva associacionista da psicologia? Não é outra, senão, a ideia de imagem intencional. "A concepção de intencionalidade é chamada a renovar a noção da imagem" (Idem, ibidem, p.144). Isto significa que se pensarmos em termos de consciência intencional, podemos supor que “...a imagem também é imagem de alguma coisa” (id., ibid., p.145). Ou seja, a imagem não é uma cópia de menor intensidade sensível de determinado objeto, mas sim mais uma forma de a consciência se relacionar com este. A imagem mental, assim como o dado da percepção sensível, é algo que a consciência intencional ultrapassa para alcançar o objeto visado. Dessa forma, se há uma árvore em meu jardim e, agora, em meu escritório, eu a imagino, ela não se trata de outra árvore, em miniatura, dentro de minha cabeça, mas é a própria e mesma árvore. A árvore que eu via ali, pela minha janela, é exatamente a mesma que eu posso imaginar agora. A diferença é que a primeira é apreendida pela consciência a partir do dado sensível visual, enquanto que a outra o é pela atitude imagética. Trata-se aqui de uma distinção de existência; existência física, captada pela percepção de um lado, e existência em imagem, captada pela ação da consciência, de outro. O que fundamenta essa distinção é a atualidade da presença do objeto (se imagino a árvore é porque ela não me é presentemente dada). Entretanto, essa distinção de existência não implica distinção de essência, logo as duas formas de presença (sensível ou imagética) se referem ao mesmo ser. A imagem é algo pelo qual a consciência se transcende, intencionando certo objeto ausente. Isto significa que quando se mostra, ela já é ultrapassada pela consciência intencionante. A imagem é “...uma relação intencional de uma certa consciência a um certo objeto" (id., ibid.). Para Sartre, essa concepção faz com que a imagem deixe de ser entendida como um conteúdo psíquico, pois o objeto por ela suscitado é algo que está fora da consciência. Em outras palavras, a imagem é a maneira pela qual a consciência se relaciona com um objeto transcendente ausente, e não um conteúdo material em seu interior.

A partir desta concepção da imagem como um tipo de relação intencional, novas possibilidades se abrem, e o gênero das imagens se amplia. Quero dizer que, segundo esta perspectiva, não apenas as imagens propriamente mentais podem ser chamadas de imagem, mas outros seres irão compartilhar dessa classificação. Na medida em que ser imagem é ser algo pelo qual a consciência alcança um objeto ausente, figuras como 
pinturas, desenhos, caricaturas e fotos podem ter essa mesma função e, neste sentido, podem igualmente serem chamadas de imagens. Por exemplo, posso ver este quadro pendurado na parede. Ele é uma tela preenchida por tintas e formas. Posso mesmo ver os traços das pinceladas. Mas minha consciência pode animar de outra maneira estes dados visuais e ver, para além da pintura, meu amigo Pedro; este quadro é um retrato de Pedro. Dessa maneira, através do quadro minha consciência intenciona Pedro da mesma forma que antes, através da atitude imagética, havia intencionado a árvore no jardim. A diferença entre ambos os tipos de imagem é apenas isto que é animado pela consciência intencionante, isto pelo qual ela visa e se transcende ao objeto. No primeiro caso, temos os puros dados sensíveis, o conceito husserliano que Sartre chama de matéria subjetiva; a hylé. Dessa forma, no caso das imagens mentais, teríamos uma hylé própria que deve ser investigada, e que certamente não é material na medida em que não é percepção, mas sim uma ação do espírito. Tal trabalho sobre a imagem seria a realização de um ponto particular de uma psicologia fenomenológica. Aqui, tratar-se-ia de determinar "o conjunto das condições que um estado psíquico deve necessariamente realizar para ser imagem" (id., ibid. p.142). Mas A Imaginação se limita a anunciar essas questões. Tais problemas são trabalhados em $O$ imaginário. Nessa obra, Sartre inventaria à exaustão os vários tipos de seres que, a partir de sua teoria, podem ser chamados de imaginários. Além disso, ele explora a estrutura intencional da imagem e trabalha o tema da hylé traduzida apenas por "matéria". A conclusão do autor é que a matéria da imagem mental se distingue daquela da percepção pois, diferentemente desta última, ela não é dada para a consciência de maneira passiva, mas ela já é constituída como um objeto para a consciência; ela é um produto da espontaneidade. Mas, para me ater aos fins desta pesquisa, encerro aqui a análise do tema da imagem, para me focar mais atentamente na questão da disputa com a psicologia positiva.

Voltando ao tema da emoção, essa manifestação psíquica também deve ser lida pela chave da intencionalidade sartreana. Como vimos, a emoção para Sartre não é a mera resposta a um estímulo ou um distúrbio psíquico. Ela, assim como todo o resto da consciência, não é o efeito de uma causalidade mecânica, pois ela tem um sentido, ela significa alguma coisa; "Significar é indicar outra coisa; e indicá-la de tal modo que, ao desenvolver a significação, se encontrará precisamente o significado. Para o psicólogo a emoção nada significa porque ele a estuda como fato, isto é, separando-a de todo o resto." (SARTRE, 1975, p.16). Relembrando o que dissemos sobre a intencionalidade, a 
consciência é um movimento de transcendência em direção ao objeto. Intencionar significa, aqui, precisamente se direcionar $a$, apontar para algo. Desta forma, pela intencionalidade, a consciência identifica a emoção com outra coisa, que não si própria. Por exemplo, se odeio Pedro, esse sentimento não seria uma reação subjetiva. Para minha consciência, é Pedro que aparece com a qualidade objetiva de ser odiável. Isso significa que um sentimento como o ódio só se dá em um contexto vivido pela consciência, e em referência a algo concreto de seu exterior. Daí este sentido intencional não poder ser redutível ao processo fisiológico correspondente, ou poder ser captado como um comportamento observável, por mais que a vivência corporal possa parecer demonstrar. A emoção não é um fenômeno que se esgota em si mesmo. O sentido intencional depende da vivência que dá significado para cada emoção. Como um ato subjetivo e intencional, a emoção em Sartre visa a alguma coisa no mundo, essa coisa dará sentido à emoção na medida em que será seu fim (assim, odiar Pedro seria uma forma de, de acordo com um projeto subjetivo, eu me relacionar com todas as injúrias que ele já me causou).

Sendo assim, o filósofo entende que a consciência emocional não é movida por causalidade, mas por finalidade (motivação). Isso significa compreendê-la como um "tipo organizado de consciência" (idem, ibidem, p.14). Desse modo, a emoção é uma forma de consciência e não um mero distúrbio, seja fisiológico, seja comportamental. A emoção, para Sartre, é uma forma particular pela qual a consciência encontra e apreende o mundo, sempre atrelada a seu sentido intencional, isto é, o objeto da emoção. Seguindo esse raciocínio, entendemos que a emoção "é na estrita medida em que significa" (id., ibid., p.16). Para que se possa compreendê-la, é fundamental a compreensão do contexto intencional, isto é, o objeto que suscita a emoção, bem como da subjetividade que esteja mergulhada nesse contexto. Sendo assim, a emoção não deve ser entendida como uma desordem de fatos fisiológicos, mas como um procedimento psíquico organizado. Ela não será nenhum efeito da realidade humana, mas será a própria realidade humana se realizando na forma de emoção. Portanto, ignorar aqui fatos fisiológicos, ou a causalidade mecânica, significa estabelecer um sentido profundamente humano para a consciência emocional. Ela é um processo significante. Indo mais além no texto, Sartre concluirá que a emoção é parte essencial do funcionamento da consciência, afirmando mesmo a impossibilidade de que haja uma consciência sem emoção. "A emoção não é um acidente, é um modo de existência da consciência, uma das maneiras como ela compreende (no sentido heideggeriano de 'verstehen') seu 'ser-no-mundo'.” (id., ibid.) 
Irei aprofundar um pouco mais a análise da emoção no próximo capítulo. Por enquanto, é suficiente ressaltar que é dessa maneira, através da intencionalidade, que Sartre entende resolver algumas dificuldades da psicologia de sua época. Quando ele propõe a formulação de uma psicologia fenomenológica, seu objetivo é fazer com que a psicologia experimental se beneficie dos resultados fenomenológicos que não fazem outra coisa senão estudar e descrever a consciência transcendental. O que significa que a fenomenologia descreve em conceitos as bases das manifestações conscientes e, portanto, precede as aparições da subjetividade e do mundo. Assim, a psicologia fenomenológica precede qualquer outra psicologia, pois esclarece seus fundamentos. O resultado disso, como vimos, é uma ciência que entende que a consciência humana nada tem a ver com as coisas materiais, pois possui características próprias e, portanto, sua metodologia de estudo deve ser diferenciada, levando em conta tais características. Ao fim, o que se apresentará é uma noção muito mais humanizada de consciência, se por isso entendermos um ser espontâneo e não reificável. 


\section{Do psíquico fenomênico; antessala do existencialismo.}

\section{1. Esta terrível máscara japonesa: uma abordagem fenomenológica da emoção.}

(...) e ele estava com a raiva tanta, que tudo quanto falava ficava sendo verdade. (Guimarães Rosa, Grande Sertão: Veredas).

O último capítulo terminou discorrendo sobre a concepção de consciência emocional desenvolvida em Emoções, mais precisamente sobre o fato de que a emoção sartreana possui um caráter significante. Esse processo de significação só é possível num sistema organizado de meios que visam fins, em outras palavras, o caráter significativo da emoção decorre de sua finalidade. Além de negar as interpretações de materialismo fisiológico que foram apontadas acima, essa tese da finalidade implica em outras consequências bastante interessantes para a obra de Sartre, apesar de não serem tão facilmente notadas. Dentre essas consequências, quero destacar o papel ativo que a consciência adquire nessa constituição do sentido da emoção. Comumente, o plano afetivo sempre foi relegado para um domínio de paixão e passividade, no qual o estado subjetivo era considerado, tão somente, como o resultado de uma causalidade, seja por parte de um evento externo, seja por outro fato psíquico. A seguir, mostrarei que a emoção, assim como a imaginação, é um modo ativo do ser da consciência. Esse modo, mais do que somente alterar o estado subjetivo, transforma toda a relação da consciência com o mundo, na medida em que transforma o próprio mundo a partir de uma atitude mágica. Além disso, destacarei a característica temporal que a finalidade acarreta para a consciência, característica essa que resolve alguns impasses - como a questão do instantaneismo psíquico apontado no segundo capítulo desta dissertação - como também abre caminhos para desenvolvimentos teóricos ulteriores da obra sartreana. Este capítulo final pretende abordar, de maneira ampla, essas "novidades" que a concepção de psíquico elaborado em E. traz para a obra de Sartre, explorada até aqui. Para iniciar estes últimos passos, começarei por descrever mais detalhadamente como se constitui a consciência emocional segundo a interpretação fenomenológica de Sartre. 
4.1.1. Para além do estado subjetivo: a emoção como uma transcendência.

Após o debate com os psicólogos e com a teoria psicanalítica nos dois primeiros capítulos do esboço das Emoções, e após ter estabelecido sua posição sobre o papel significante da emoção, Sartre inicia o terceiro capítulo dessa obra apresentando uma descrição fenomenológica das emoções, de modo a resolver as questões que ficaram em aberto nos capítulos anteriores. Esta dissertação já citou algumas vezes as mudanças conceituais que o psíquico passa a ter nessa obra. Contudo, pretendo mostrar que essas mudanças não fazem parte de uma ruptura e, certamente não sendo mera continuidade, as inovações teóricas se tratam de um desenvolvimento e um aprofundamento da obra que vinha sendo elaborada desde o artigo sobre a Intencionalidade. Claro que todo desenvolvimento só pode ocorrer num campo de tensões, como será mostrado adiante.

Retomando, brevemente, o que já foi exposto nos dois primeiros capítulos desta dissertação sobre as características da consciência emotiva no primeiríssimo Sartre (em I. e T.E.), lembramos que sua característica principal, assim como a de todas as modalidades da consciência, é a transcendência via intencionalidade. Em outras palavras, a emoção foi concebida como mais uma maneira de a consciência encontrar o mundo. “(...) temível, hostil, com refúgios de graça e de amor.” (SARTRE, 2003a, p. 89). Portanto, desde o ancestral artigo sobre a Intencionalidade, o autor já adiantava que a consciência emotiva se tratava de muito mais que um mero distúrbio ou alteração acidental e pontual num sujeito dentro de um mundo inalterado, ao contrário, era uma consciência que, ao mergulhar no mundo, tingia-o inteiramente com suas próprias cores; a transformação é absoluta e total nos dois lados da relação. Acompanhando a descrição fenomenológica da emoção desenvolvida no esboço das Emoções, podemos ver que, a despeito de todas as tensões conceituais, essa concepção do início dos anos 30 recebe um aprofundamento detalhado no final dessa década.

Sartre inicia o terceiro capítulo do opúsculo das Emoções destacando, como observação preliminar, um equívoco que pode ser atribuído a todas as teorias psicológicas tratadas nas páginas anteriores (com exceção da de Dembo e seu campo de tensões); tomar a emoção sempre como sendo uma consciência reflexiva ${ }^{57}$, isto é, que se sabe

\footnotetext{
${ }^{57}$ Aliás, desconsiderar a primazia da consciência irrefletida de primeiro grau era o mesmo erro que fazia alguns filósofos afirmarem a presença do Ego no interior de todas as vivências. Portanto, a exigência metodológica de aceitar apenas os dados imediatos da consciência irrefletida continua sendo mantido desde
} 
enquanto um estado de consciência emocionado. Num caminho argumentativo que remonta a seus dois primeiros artigos, o autor afirma que por conta da intencionalidade e da prioridade da consciência irrefletida de primeiro grau, "A consciência emocional é, em primeiro lugar, consciência do mundo.” (SARTRE, 1975, p. 55). Ou seja, há uma síntese indissolúvel entre o sujeito emocionado e o objeto emocionante; de modo que, irrefletidamente, a emoção se mostra como uma maneira de apreender o mundo.

Para defender essa tese, Sartre investiga a consciência da ação para mostrar que a atitude prática do sujeito no mundo não necessita da mediação de uma consciência reflexiva. Tomemos o exemplo de uma ação que fracassa como num jogo de videogame: o jogador tenta passar de fase diversas vezes, mas sempre deixa o personagem morrer em determinado obstáculo. Após diversas tentativas frustradas, ele finalmente irrita-se e joga o controle no chão. Para tal ação, ele não precisa ponderar sobre a dificuldade daquele obstáculo que não pôde ser superado por sua habilidade como jogador. A conduta de atirar o controle no chão apenas expressa e traduz a apreensão de jogo-odioso que sua consciência realiza irrefletidamente. Esse processo pelo qual o jogo deixou de ser um entretenimento desafiador, para apresentar-se como estorvo odioso, se dá de maneira direta e contínua no plano irrefletido. Ou seja, a partir da consciência irrefletida do jogo cativante, não preciso fazer um retorno reflexivo ao mim fracassante para, depois, voltar irrefletidamente ao jogo apreendido como irritante. Segundo Sartre, ocorre apenas uma transformação direta da forma "mundo-agido" para a forma "mundo-odioso". Ainda segundo o autor, é desse modo que se dão a maioria das ações, sem o abandono do plano irrefletido.

Desenvolvendo essa posição, Sartre retorna àquela conclusão já alcançada durante a crítica à psicanálise; irreflexão não significa inconsciência. Pelo fato de eu não perceber cada uma de minhas condutas durante determinado procedimento, isso não significa que eu esteja inconsciente delas, de modo que estariam vindo de fora de minha consciência ${ }^{58}$, por princípio, isso seria absurdo. Ocorre que a consciência irrefletida é consciência não tética de si. A maneira não tética da consciência da ação (e da emoção que lhe seja sucedânea) é perceber-se como qualidade no mundo.

A Transcendência do Ego, mesmo que no Esboço das Emoções, como será visto, o instantaneismo da evidência pura sofrerá importantes reconsiderações.

${ }^{58}$ Esse agente externo poderia ser tanto a causa material de um distúrbio fisiológico, quanto o inconsciente freudiano. 
Uma vez compreendida essa transcendência da consciência emotiva, pode-se, agora, apresentar uma definição mais precisa do que é a emoção: trata-se de uma transformação do mundo realizada pela consciência; quando os caminhos para a ação se encontram demasiadamente obstruídos ou impossíveis, então, para sair da situação de urgência imposta pela impossibilidade, a consciência substitui as relações deterministas do mundo pela relação mágica.

\subsubsection{Do mundo da magia: o ser humano é um feiticeiro.}

Aqui retorna o tema da magia que já havia sido exposto em T.E. (citado na página 58 desta dissertação). Esse termo aparece em diversos momentos ao longo dos anos 30, seu sentido certamente muda de uma obra para outra, no entanto suas características principais são mantidas. Magia, em toda obra sartreana, é a atitude pela qual a consciência rompe o determinismo do mundo objetivo para, assim, impor suas determinações sobre esse mundo. Isso não diverge muito da acepção comum da palavra. O mágico profissional não faz outra coisa senão alterar, inesperada e inexplicavelmente, a ordem do mundo. Certamente, um coelho que sai de dentro de um cartola, que a pouco estava vazia, rompe com a expectativa determinista de que, na ordem natural, coelhos não surgem do nada. É este sentido de ruptura com o determinado que se mantém em todas as referências sartreanas. Mas, assim como o mágico de palco é apenas um ilusionista e não faz, de fato, o coelho brotar do nada, também a atitude mágica da consciência não subverte nenhuma lei metafísica, ela é apenas um truque pelo qual a consciência alcança seus objetivos, não obstante, trata-se de um truque bastante sério, no qual ela própria enfeitiça-se junto com o mundo.

Portanto, os caracteres gerais da magia são a quebra da expectativa determinista, a transformação repentina, a ininteligibilidade e o irracional. Esses caracteres são mobilizados com objetivos diferentes em cada menção que Sartre faz do mágico. Às vezes, sua utilização tem um caráter pejorativo de flertar com o equívoco ${ }^{59}$, esse caráter equívoco descreve, sobretudo, a estranha espontaneidade apassivada da dinâmica

\footnotetext{
${ }^{59}$ Essa é a forma com a qual, em T.E., a magia descrevia as relações de produção e emanação do Ego com seus estados e qualidades; relações ininteligíveis que apenas mascaravam a espontaneidade vertiginosa da consciência que se objetivava no Ego.
} 
egológica ${ }^{60}$. Mas, em outras ocasiões, a mágica é apresentada como uma propriedade da absoluta soberania da consciência, que mais do que apenas apreender passivamente o real, supera-o, transformando o mundo e a si própria. Ou seja, nesta acepção, mágica sugere liberdade. Sendo erro ou liberdade, alienação ou criação, a mágica é uma categoria fundamental para a compreensão da dinâmica espontânea da consciência e, mais do que descrever meras transformações pontuais, a mágica constitui todo um mundo próprio.

Já que a magia descreve uma propriedade tão importante do objeto desta pesquisa, parece ser proveitoso acompanhar, brevemente, a leitura fina realizada por Coorebyter desse termo. O comentador belga identifica quatro sentidos principais do mágico em toda a obra sartrena: 1. O sentido de sacralização dos objetos; é através desse sentido que a consciência, arrastando-se nas coisas, pode tornar sagrado um objeto material, como um ídolo ou imagem sacra. Este é o modus operante dos rituais religiosos, trata-se do sentido antropológico da mágica que aparece, sobretudo, nos Diários de uma Guerra Estranha. 2. Sentido de irrealização do mundo, através do qual a consciência expressa sua liberdade, imprimindo no mundo suas próprias determinações, seja através da imaginação quanto através da emoção, este é o sentido que aparece no esboço das Emoções. 3. Sentido contraditório; descreve a quase espontaneidade da vida psíquica, ou seja, sua propriedade de, ativamente, transformar o mundo, ao mesmo tempo em que se objetifica nesse processo. Os estados descritos em T.E. refletem bem esse sentido, é a consciência que, por seu próprio poder espontâneo, tenta identificar-se com o modo de ser passivo da coisa em si. O Ser e o Nada apresentará alguns exemplos desse sentido do mágico. 4. O sentido estético; trata-se do sentido de criação artística rumo ao Belo, ou seja, seria o ultrapassamento das formas plásticas do real com fins estéticos. Esse sentido é encontrado em Situações I. (COOREBYTER, 2000, p. 487).

Essa lista dos diferentes sentidos do mágico embasa ainda mais aquilo que foi dito acima, que a mágica descreve fundamentalmente o caráter irracional da vida psíquica. Mais do que afirmar, prosaicamente, que um sujeito emocionado não age de forma racional - que está "fora de si”, o que Sartre está fazendo é uma delimitação sofisticada do campo de atuação e da metodologia das ciências da emoção. Neste sentido, identificar

\footnotetext{
${ }^{60}$ Recapitulando o que foi explicado no segundo capítulo desta dissertação, espontaneidade passiva é a forma como a consciência, projetando-se no objeto Ego, vê este último como uma espontaneidade criadora dos estados e emoções, apesar de ele ser um objeto constituído e passivo. Essa espontaneidade passiva, repito, trata-se tão somente da espontaneidade da própria consciência irrefletida mascarada no Ego.
} 
o psíquico com o mágico significa interditar à psicologia pretensões cientificistas conforme foi tratado no capítulo anterior desta dissertação. Desde que o domínio psíquico seja regido por relações não determinísticas, relações que expressam um modo especial e essencial do ser da consciência, espontâneo e subjetivo, então a abordagem objetivista das psicologias positivistas teria pouco a dizer sobre a dinâmica emocional. Desse modo, a magia se mostra como um campo privilegiado de estudos, principalmente porque é ela quem descreve as relações intersubjetivas, conforme Sartre afirma em sua famosa expressão de que "o homem é sempre um feiticeiro para o homem"61, expressando, assim, a peculiar relação de objetificação da consciência, transcendência da imanência, que a interação com outrem pressupõe. Entretanto, o escopo do esboço das Emoções - a obra que melhor aborda o tema da magia - é limitado, como o próprio autor explicita na introdução e na conclusão do opúsculo. O objetivo aqui seria abrir um campo de pesquisas baseadas na reflexão fenomenológica eidética sobre a emoção. Sartre esperava apenas mostrar a possibilidade de um tal estudo com sua obra, cabendo aos psicólogos desenvolverem monografias sobre os temas da psicologia fenomenológica ${ }^{62}$. Além disso, Sartre não dará a esperada continuidade do tema em O Ser e o Nada. Segundo Coorebyter, isso ocorre, pois nessa obra o autor não precisa recorrer ao mágico, já que ultrapassa o dualismo entre corpo e consciência, transformando o próprio corpo em psíquico ${ }^{63}$. Ainda assim, mesmo que um possível projeto ontológico do domínio mágico seja precocemente abandonado na obra sartreana, essa categoria sempre continuará valendo para expressar as relações de ininteligibilidade entre o psíquico e o corpo. Como já foi dito, essas relações constituem muito mais do que comportamentos pontuais, mas formam um verdadeiro mundo; o mundo da magia, morada da consciência emocional, que será exposto mais afrente.

A definição mais geral da emoção é, portanto, um encantamento do mundo. A compreensão sobre como se dá tal encantamento é de uma importância capital para os objetivos desta pesquisa. Sendo assim, os próximos parágrafos irão se aprofundar naquele

\footnotetext{
${ }^{61}$ SARTRE, 1975.

62 "Desejaríamos, especialmente desse ponto de vista, que nossas sugestões abrissem o caminho para estudos monográficos completos da alegria, da tristeza, etc. Fornecemos aqui apenas as direções esquemáticas de tais monografias." (Idem, ibidem, p. 65)

63 “O Ser e o Nada prescindirá, então, da categoria do mágico uma vez em que tentará ultrapassar o dualismo, tornando o corpo inteiramente psíquico" (COOREBYTER, 2000, p. 489).
} 
segundo sentido do mágico apresentado por Coorebyter, que vale a pena ser citado na íntegra:

(...) a emoção e, em uma menor medida, as pantomimas da imaginação e o jogo do ator, dão condutas mágicas de desrealização do mundo ou de realização do imaginário: a liberdade tenta, assim, desvitalizar o concreto, ou materializar as vistas do espírito para escapar de sua situação-nomundo. O mágico toma, desta vez, um sentido original, que qualificaremos de existencial como o faz o Esboço (das Emoções). (COOREBYTER, 2000. p, 487).

Ora, não seria exagerado afirmar que a emoção é um ato existencial da consciência, conquanto que compreendamos como funciona tal ato. Segundo Sartre, a transformação mágica do mundo é, na verdade, uma mudança de atitude da consciência. É importante salientar que essa mudança não é consciente de si enquanto mudança, pois, mais uma vez, estamos diante de uma consciência irrefletida que está voltada para o mundo e que não faz de sua ação o objeto de uma reflexão ${ }^{64}$. Daí essa mudança de atitude não se tratar de um jogo, pois a consciência se torna cativa de sua própria mudança. Mais adiante irei desenvolver melhor a apreensão cativante do mundo da emoção. Mas, primeiramente, é importante acompanhar como o autor justifica essa possibilidade de uma mudança de atitude da consciência. Para argumentar em favor disso, Sartre afirma que estamos acostumados a essas mudanças, lembrando que isso ocorre comumente com a consciência perceptiva. $\mathrm{O}$ autor exemplifica isso com o caso das gravuras charadas ${ }^{65}$, ele cita a gravura do caçador escondido nas árvores, aqui quando o observador se esforça para encontrar a figura proposta pelo desafio, a consciência perceptiva passa, irrefletidamente, da atitude "paisagem de árvores" para a atitude "caçador escondido". A consciência realiza esse mesmo tipo de mudança irrefletida na atitude emocional quando, para alcançar seus fins, transforma a si própria para apreender o mundo através de uma forma nova.

Ilustremos como funciona o encantamento do mundo na vida quotidiana. Sartre utiliza um exemplo semelhante à fábula da raposa e as uvas. Quando o personagem está sob um cacho de uvas que pretende comer, há o objeto noemático "uvas-a-seremcolhidas". O sujeito estica o braço e não alcança seu objetivo, então, dando de ombros, desdenha das uvas dizendo que estavam muito verdes. A transformação mágica seria a

\footnotetext{
${ }^{64}$ Aliás, é justamente por ser irrefletida que essa mudança de atitude da consciência dá a impressão de que a conduta emocional seja um processo inconsciente. Estamos diante, mais uma vez, das ambiguidades da espontaneidade apassivada do ser psíquico encarnado pelo Ego.

${ }^{65}$ SARTRE, 1975, p. 44-45.
} 
própria atitude de desdém do personagem. Quando se vê impossibilitada de alcançar seu objetivo inicial, a consciência realiza uma transformação efetiva das relações do corpo com o mundo (bater de ombros, torcer a boca, enfim, desdenhar) para, assim, transformar as uvas no objeto noemático "muito-verdes". Como não pode alterar a estrutura química das uvas, a consciência transforma magicamente o cacho através da conduta de desdém. Veja-se que isso não se trata de um mero fingimento, apesar de Sartre descrever esse exemplo como uma comédia executada sob as uvas ${ }^{66}$, a consciência, através da conduta corporal, realmente se convence de sua própria atuação, só assim pode ir embora sem lamentar a incapacidade de alcançar aquele cacho outrora atraente. A magia está, portanto, na alteração das propriedades do mundo, quando essa alteração é levada a sério pela consciência. Não se trata de um mero achismo, trata-se de uma apreensão irrefletida e efetiva do mundo com propriedades novas, propriedades que não poderiam ocorrer naturalmente. Voltemos ao caso do jogador de videogame que se irritara com seu fracasso. Onde está a mágica na conduta de atirar o controle no chão e se aborrecer com o jogo? Ora, todas as pessoas já devem ter provado o sentimento de resignação como um dos mais amargos existentes; aceitar um prejuízo que, impunimente, o destino nos impõe. Males sem culpados, sem responsáveis, são um verdadeiro absurdo existencial. Analisando a História política, seria desnecessário citar quantas e quantas vezes as sociedades precisaram encontrar um "culpado" por suas crises. Enfim, está claro que, por conta dessas razões, uma das características mais comuns da conduta humana é terceirizar a culpa por seus infortúnios. A atitude de atirar o controle no chão expressa isso. Não se trata apenas de "descontar" a raiva no objeto que está às mãos, mas de imputar culpa, responsabilidade, punibilidade para o objeto inanimado que, através dessa conduta, se torna magicamente odiável, irritante, etc. Eis, portanto, o que significa encantar o mundo: conferir humanidade para as coisas. O exemplo de irritação para com objetos inanimados é paradigmático nesse sentido. Todos que acidentalmente já chutaram a quina do sofá ou da mesa com o dedinho do pé sabem que, frente à dor aguda, a primeira atitude quase sempre é xingar o objeto chutado e não nossa inépcia motora. O sofá "maldito", "fora do lugar", é o exemplo mais prosaico de como o ser humano encanta o mundo quando humaniza a absoluta passividade neutra de sentido do ser em si. Assim como fazemos com as outras pessoas, também queremos culpar os objetos inanimados por nossas

\footnotetext{
${ }^{66}$ SARTRE, 1975, p. 45.
} 
mazelas. Em ambos os casos ocorre uma terceirização da responsabilidade, mas no segundo há uma terceirização mágica.

Portanto, a conduta mágica pode, finalmente, ser entendida como uma das atitudes mais comuns e frequentes da consciência humana. Ela é a expressão mais clara da espontaneidade livre da consciência que, não podendo viver em si mesma, está sempre explodindo na direção do mundo, encontrando-se nesse mundo, enfim, encantando esse mundo ao conferir-lhe suas próprias características. Mas uma ressalva precisa ser feita, a mágica da consciência é um procedimento no qual o feiticeiro se enfeitiça junto com seu objeto. Sendo assim, ela é um atributo da liberdade essencial da consciência que pode, ambiguamente, acarretar em aprisionamento. Como já foi dito acima, o termo do mágico pode comportar acepções negativas. Ora, o personagem das uvas pôde resolver a tensão emocional derivada da incapacidade em alcançar alguns metros acima, o gamer pôde canalizar sua frustração. No entanto, na dimensão prática, o primeiro foi embora com fome e o segundo encerrou sua diversão não conseguindo passar de fase. Daí pode-se antever um potencial alienante da magia, ele ocorre quando a consciência utiliza sua liberdade de criação de sentido unicamente para fugir de sua situação. Ou seja, no domínio da ação, a magia contrasta com a práxis, estando próxima do desejo alienante. Esse sentido - que já depende do estudo da dialética - só será realmente desenvolvido em O Ser e o $\mathrm{Nada}^{67}$. Chamo aqui a atenção para isso, no intuito de salientar o papel importante que a ação desempenha na constituição do sentido da emoção. Tanto quanto criação de sentido, quanto como fuga da realidade, a consciência mágica tem uma ligação essencial com a ação, conforme será explorado na próxima seção.

\subsubsection{Da consciência ativa: engajamento no mundo e lacuna teórica.}

Esta dissertação já explicitou seu objetivo de apontar para as consequências éticas e existenciais que podem ser tiradas da fase fenomenológica de Sartre. Seguindo esse objetivo, chama atenção o fato de o filósofo ter apresentado o modo irrefletido da consciência emocional a partir da descrição da consciência da ação, conforme foi exposto nas páginas acima. A emoção, portanto, está intimamente vinculada com a ação da

\footnotetext{
67 “Um primeiro olhar sobre a realidade humana nos ensina que, para ela, ser se reduz a fazer. Os psicólogos do século XIX que mostraram as estruturas motrizes das tendências, da atenção, da percepção, etc., tiveram razão (...) Assim, a realidade humana não está, por princípio tendente à ação, mas para ela ser é agir, e cessar de agir é cessar de ser.” (SARTRE, 2011, p. 521)
} 
subjetividade que, não cansamos de repetir, só ocorre em referência ao mundo transcendente. Isso significa que a emoção não é uma transformação acidental e desinteressada da consciência frente a qualquer situação, ao contrário, a queda na emoção está associada aos percursos ativos que a subjetividade traça no mundo. Emoção tem a ver com os projetos subjetivos. Admite-se, desde aqui, as dificuldades desse tema. Como é largamente conhecido, Sartre não desenvolve uma teoria da ação nas obras anteriores ao Ser e o Nada. Além disso, no ensaio de ontologia fenomenológica a descrição da consciência ativa já é realizada sob um prisma muito diferente do que as investigações de psicologia fenomenológica pressupõem. No entanto, tanto em T.E. como no esboço das Emoções, a investigação da consciência ativa é mencionada para os fins da descrição do psíquico, não obstante essa investigação seja, nos dois casos, explicitamente postergada para outro momento que não viu a luz nas obras sartreanas de que temos conhecimento ${ }^{68}$. Ainda assim, a despeito da esquiva de Sartre para tratar da consciência ativa, a menção dela, em mais de um momento das obras dos anos 30, revela que uma teoria da ação está subjacente à descrição fenomenológica do ser psíquico. Mais ainda, essa teoria é tão importante que, mesmo inacabada, é digna de menção nesses momentos supracitados. Portanto, pretendo desenvolver nos próximos parágrafos alguns comentários sobre a consciência ativa na psicologia fenomenológica sartreana. Tendo total noção das limitações desta pesquisa para reconstituir toda uma teoria que o próprio autor não terminou, meus comentários pretendem, tão somente, elucidar a importância do tema e apontar, modestamente, alguns possíveis desdobramentos e as lacunas teóricas que restaram.

O que há em comum com todas as manifestações emotivas já exemplificadas, é que elas são decorrentes de uma urgência do mundo, essa urgência, por sua vez, é sucedânea de uma atividade da subjetividade que se vê, subitamente, impossibilitada, obstruída, exigida, frustrada, desejada, imperada, enfim, uma atividade que vê seus caminhos truncados pela conjuntura do real. O mundo das exigências, como afirma Sartre (1975) é o correlato noemático de nossa atividade empreendida ou simplesmente concebida. Sendo assim, fica claro que - pelo menos na maioria dos casos, pois as

\footnotetext{
${ }^{68}$ Talvez, assim como o tema da temporalidade, a consciência ativa possa ter sido explorada naquele que deveria ter sido o grande livro de psicologia fenomenológica: La psyché. No entanto, o próprio Sartre optou por nunca publicar tal obra, da qual o Esboço para uma teoria das emoções seria o único extrato que o autor revelou ao público. Mas, essa e muitas outras hipóteses sobre essa que poderia ter sido a principal obra dos anos 30, estão fadadas a se restringir ao plano da especulação.
} 
exceções serão tratadas na seção subsequente desta dissertação - é a partir da ação que a consciência tem a ocasião de se transformar magicamente na emoção. Ou seja, assim como ocorre com a percepção, também através dos atos percebemos o mundo.

As implicações teóricas disso vão totalmente de acordo com as consequências éticas já mencionadas da imersão ontológica do sujeito no mundo; a subjetividade está longe de ser uma substância pensante que apenas testemunha a realidade, contemplando à distância o mundo, submetendo-o às categorias da cognição, ao contrário, a subjetividade se constrói em seu mergulho no mundo, e o próprio mundo, correlativamente, é apreendido segundo os projetos, pontos de vista e interesses dessa subjetividade engajada. Como já foi dito, ser é ser-no-mundo. Ontologicamente, isso já havia sido assegurado desde T. E., agora, uma descrição da consciência na ação poderia fornecer os detalhes de como se dá, formalmente, essa imersão no mundo. Entretanto, como tal teoria não foi elaborada, nos resta destacar e descrever seus meros perfis que foram apresentados nas obras dos anos 1930.

Retornemos, brevemente, ao exame das ações realizado em T.E. Lá, Sartre utilizava um certo tema diretor para dar coesão às consciências que se sucediam na ação. $\mathrm{O}$ tema diretor funcionava como o fio condutor que guiava um complexo de consciências ativas que, não fosse ele, arriscavam cair numa sucessão caótica devido sua aparição ex nihilo. Era assim que, o ato de beber água poderia ocasionar o esfaqueamento de meu vizinho $^{69}$. Deixei esse tema em aberto no segundo capítulo desta dissertação para, agora, poder desenvolvê-lo melhor. Apesar de ainda não ter respostas definitivas, esta pesquisa tem, neste momento, pelo menos, ferramentas para abrir mais a discussão. Do que já foi exposto no segundo capítulo, ficaram duas questões: 1. De onde viria esse tema diretor? 2. Sua projeção nas ações futuras sobreviveria ao critério instantaneista da reflexão pura (o que significa perguntar se ele é característica da consciência transcendental, ou meramente um falso objeto como o Ego)?

1. Exploremos a primeira pergunta. A descrição fenomenológica do Ego não oferece respostas para ela. O fato é que em T.E. Sartre faz uso dessa noção para conferir coesão às sucessivas consciências ativas. $\mathrm{O}$ tema diretor transcendia cada um dos atos que guiava rumo à concretização da ação. Mas nenhuma dessas consciências o colocava, ele era pressuposto por elas. No segundo capítulo desta dissertação, afirmei que ele

\footnotetext{
${ }^{69}$ Vide a nota 40.
} 
poderia ser o fruto de um ato volitivo irrefletido. Isso parecia fazer sentido se considerássemos os imperativos da ação como propriedades objetivas do mundo "trema-ser-pego", "copo-que-deve-ser-enchido", etc. Mas, analisando mais profundamente, é forçoso admitir que uma "volição irrefletida" apenas atrasaria o problema, pois logo surge a questão: De onde vem a volição? O senso comum - e boa parte do que já exploramos responderia rapidamente: da liberdade da consciência. Entretanto, há que se admitir que volição é um ato deveras carregado de sentido e conteúdo e, portanto, não pode ser fruto da liberdade descrita por Sartre como uma característica do próprio ser da espontaneidade da consciência impessoal. Uma breve análise da liberdade e sua relação com a vontade pode, portanto, elucidar um pouco esse problema.

Qualquer pessoa que tenha lido com um mínimo de atenção o existencialismo sartreano, ou mesmo levado em conta o que esta dissertação já afirmou sobre a liberdade da consciência, principalmente no capítulo anterior, verá que liberdade, para Sartre, não tem a ver com livre-arbítrio. Apesar de o filósofo fazer, como vimos, uma crítica radical do determinismo, isso não significa que a liberdade da consciência possa ser identificada com o voluntarismo do que se entende por livre-arbítrio. A liberdade é uma condição intrínseca do próprio ser transcendental e espontâneo da consciência. Uma vez que ela não é colocada no mundo por nenhuma outra coisa senão ela mesma, e pelo fato de não compartilhar das propriedades físicas e materiais das coisas em si, a consciência é, na raiz de seu ser, completamente indeterminada e, portanto, livre. Por outro lado, livre arbítrio pode ser lido como "vontade livre"70. Ora, precisamente, a vontade se trata de um aspecto do ser psíquico e, portanto, é mais um dos objetos da consciência transcendental irrefletida. Sendo assim, pode-se afirmar que a liberdade da consciência não pode estar associada com o voluntarismo subjetivista ${ }^{71}$.

Apesar de o tema diretor não poder ser fruto da liberdade voluntarista, isso não significa que as afirmações feitas no segundo capítulo ficam invalidadas após as análises dos livros sobre psicologia fenomenológica. Não por acaso, eu havia chamado a fonte do tema diretor de "volição irrefletida", isso para indicar que a coesão das ações certamente era trabalho da consciência de primeiro grau e não do domínio psíquico pessoalizado. Acontece que no Ensaio sobre a Transcendência do Ego, Sartre ainda não havia realizado

\footnotetext{
${ }^{70}$ Neste sentido, a tradução do termo em inglês como free will é reveladora.

${ }^{71}$ Para aprofundar este tema, vale a pena acompanhar o artigo Towards a theory of action in Sartre's philosophy de André Barata, devidamente citado na bibliografia.
} 
uma investigação detalhada da dinâmica psíquica frente ao mundo - que identificamos como a vida emotiva. Agora, de posse dessa investigação, repito o que também já havia adiantado no segundo capítulo; o que em T.E. podia ser chamado de tema diretor, em Emoções pode ser associado com a finalidade da emoção. Portanto, respondendo à primeira questão colocada, o que confere unidade - e, portanto, racionalidade, diga-se até teleologia - para as consciências ativas, é o projeto colocado, espontaneamente, pela consciência impessoal e irrefletida. Não se trata do querer de um Mim, mas do modo como a consciência se joga no mundo.

2. A resposta para a segunda questão é mais fácil de ser fornecida: Não; a indicação de continuidade do tema diretor, doravante chamado de projeto, não sobreviveria aos critérios de evidência radicais da reflexão pura. Entretanto, essa resposta negativa não entra em contradição com o que acaba de ser afirmado no fim do último parágrafo. Antes de contradição, o que está ocorrendo aqui é um tensionamento teórico no pensamento do autor. Isso explica porque de no esboço sobre as Emoções Sartre não mencionar mais a reflexão pura, oferecendo, no lugar dela, uma reflexão eidética da consciência emotiva ${ }^{72}$. Esse tema será aprofundado no próximo subcapítulo, por enquanto, o que importa fixar é que, mantendo a ideia de que o sentido das consciências ativas parte da consciência irrefletida, Sartre propõe, agora, que esse sentido se mantém para além da instantaneidade de uma consciência pontual; não é outra coisa que o termo projeto quer sugerir.

A ação, portanto, só faz sentido no contexto de um projeto da consciência irrefletida que "vê" no mundo os caminhos de realização e obstrução de sua atividade. Esse projeto, por sua vez, não é fruto da vontade, pois conforme Barata (2018, p. 126) essa só aparece pela consciência refletida, na forma de testemunha correlata da ação que é realizada. Uma vez que o processo significante, subjacente ao projeto, é revelado pela conduta emocional, isso mostra uma consequência bastante interessante da filosofia sartreana que a destaca de uma longa tradição. Aqui, a emoção é a alteração do mundo para conformá-lo de acordo com os caminhos necessários à ação da consciência, sendo

\footnotetext{
72 “Tentaremos nos colocar no terreno da significação e tratar a emoção como fenômeno." (SARTRE, 1975, p. 19). "Uma psicologia fenomenológica segura de si, e que tivesse previamente se desembaraçado do que lhe estorva, começaria por fixar numa reflexão eidética a essência do fato psicológico que ela interroga". (idem, ibidem, p. 65)
} 
assim, emoção não deve ser entendida unicamente como paixão e, portanto, passividade. Há um componente ativo intrínseco ao comportamento emotivo que expressa, não apenas padecimento, mas também os poderes da indomável liberdade da consciência.

Acredito que o que acaba de ser exposto dá conta dos pontos principais que podem ser explorados no que concerne ao tema da consciência ativa da psicologia fenomenológica de Sartre. O que podemos compreender é que a consciência da ação, não sendo tética de si enquanto agente, "vê" no mundo a exigência de sua atividade como uma qualidade objetiva.

\begin{abstract}
O que importa aqui é apenas mostrar que a ação como consciência espontânea irrefletida constitui uma certa camada existencial no mundo, e que não há necessidade de ser consciente de si como agente para agir - muito pelo contrário. Em suma, uma conduta irrefletida não é uma conduta inconsciente, ela é consciente dela mesma não teticamente, e sua maneira de ser teticamente consciente de si é transcender-se e perceber-se no mundo como uma qualidade de coisas. Assim pode-se compreender todas as exigências e as tensões do mundo que nos cerca (...). (SARTRE, 1975, p. 42)
\end{abstract}

Essa tese torna ainda mais dinâmica a liberdade vertiginosa da consciência que, contudo, não pode ser identificada com o voluntarismo pessoal. Mas, como o próprio Sartre (1975) avisa, ele tentaria descrever o mundo agido em outra parte. Para André Barata, essa descrição se encontra, principalmente, no capítulo sobre a vontade e a liberdade de $\mathrm{O} \operatorname{Ser}$ e o $\mathrm{Nada}^{73}$. O comentador português sintetiza muito bem essa descrição apresentando os elementos correlatos motivos e móveis da ação. Os motivos seriam o polo objetivo que impulsiona a ação (a situação mundana), enquanto que os móveis seriam o polo subjetivo (o conjunto de desejos, vontades, etc.). Nessa tese apresentada em $O$ Ser e o Nada, percebe-se que a ação não é o resultado nem de um impulso interior e nem de uma demanda exterior, já que é o resultado dessa estrutura correlata. Além disso, a vontade - elemento da pessoalidade psíquica - não é vista como a agente deliberativa, e sim como mera testemunha da ação. Ou seja, a volição só aparece quando a decisão já foi tomada. Em outras palavras, é à espontaneidade da consciência irrefletida que se deve o exercício das ações. Essa tese mostra que a obra de ontologia fenomenológica não rompe, mas aprofunda os principais aspectos da ação conforme tratamos até aqui. A interpretação de Barata me parece esclarecedora, mas para ater-me nos fins desta pesquisa, encerro aqui o que pode ser depreendido da consciência ativa nas obras dos anos 1930, mesmo que reste algumas lacunas incômodas. Toda a tensão

\footnotetext{
${ }^{73}$ BARATA, 2018, p. 128.
} 
conceitual está, pois, no fato de que a consciência se sucede no futuro orientada através do tema diretor. Não obstante, a consciência não sofre causalidade nem de objetos externos e nem de outros estados mentais passados. Assim, em Emoções, as consciências que reclamam cada momento da ação continuam surgindo ex nihilo (SARTRE, 1975, p. 42), retroativamente elas não se remetem a nada, ao mesmo tempo, cada um desses momentos se orienta num objetivo comum. É como se retroativamente a consciência não pudesse encontrar lastro temporal, ao mesmo tempo em que o faz, através de protensões, no futuro e, quando a próxima consciência surge, ela já não pode mais ser remetida à anterior. Temos aqui, portanto, uma dificuldade difícil de solucionar. O problema parece estar não no fato de a consciência não sofrer causalidade de seus próprios estados passados, mas da dificuldade de Sartre em considerá-la temporal e sinteticamente conectada com esses estados. É o fluxo da consciência que, embora já fosse admitido desde T.E., encontra dificuldades em ser conceitualizado até em Emoções. A grande lacuna é, portanto, a temporalidade, conforme o próprio autor admitirá nos Diários de uma Guerra Estranha. De qualquer forma, analisando a trajetória dos textos dos anos 30, há que se reconhecer ganhos conceituais nesse sentido, conforme irei trabalhar separadamente algumas páginas adiante.

Acredito que o que foi exposto embasa pontos importantes do que esta pesquisa vem tentando defender; a relevância de se interpretar a consciência sartreana como uma função ativa no mundo. Pois, quando consideramos a ação como a condição da emoção, vemos que agir, para a consciência, não significa somente mover espacialmente o corpo e os objetos; ação descreve o próprio movimento do ser da consciência. Além disso, também se embasa mais, desde aqui, outra coisa que procuro defender; a fundamentação do existencialismo sartreano a partir de seus estudos de fenomenologia. A menção de como o artigo de Barata relaciona e conclui o tema da ação entre as obras dos anos 1930 e $O$ Ser e o Nada é uma explicitação disso.

Vê-se, portanto, um vínculo indissociável entre ação e emoção. Pelo menos na primeira forma da emoção (a seguir será apresentada uma segunda forma), o mundo só sofre o encantamento mágico quando a ação da consciência irrefletida enfrenta algum obstáculo ou frustração. Já é possível antecipar que essa ligação entre consciência ativa e consciência emotiva abre um leque de interpretações sobre a ética da volição e da liberdade. Por enquanto, a consequência dessa forma irrefletida que a maioria das ações têm, é que elas constituem uma camada existencial no mundo. Isso vem da exigência 
exercida por cada um dos passos da ação (voltando ao jogo de videogame: "buraco que deve ser saltado", "inimigo que deve ser enfrentado", "chefe de fase a ser derrotado", etc.). Enfim, a consciência, no intento de cumprir seus projetos, utiliza-se da emoção para recobrir o mundo com uma roupagem completamente nova. Há, portanto, um verdadeiro mundo da emoção, que pretendo expor agora.

\subsubsection{Do mundo da emoção.}

Vimos que a consciência, por oportunidade da ação e através da atitude mágica, recobre o mundo com uma verdadeira camada existência, é como se o poder de constituição de sentido da consciência dotasse o mundo com uma carga ontológica extra além daquela já contida na massa densa que o ser em si oferece à percepção. Mas vale lembrar que, se tratando da fenomenologia descrita por Sartre, não há uma separação entre o sujeito e seu objeto, a totalidade consciência/mundo prevê uma correlação constante entre seus dois elementos. Conforme foi mostrado acima, os planos de ação da subjetividade formam um entrelaçamento de caminhos que constituem o correlato noemático da consciência ativa. Sendo a consciência um perpétuo movimento, ultrapassamento de si e da realidade, seu correlato noemático não pode se restringir a mudanças pontuais e localizadas; a totalidade sintética que constitui o ser da consciência se estende para o mundo encantado pela magia. Sendo assim, não existem momentos ou objetos emotivos, há todo um mundo da emoção. Pretendo fazer algumas considerações sobre esse mundo nos próximos parágrafos.

Afirmar que existe um verdadeiro mundo da emoção significa dizer que quando a consciência realiza uma transformação afetiva em sua vivência, ela não o faz em um objeto individual que permaneceria num mundo inalterado, significa que essa transformação é massiva e o mundo é transformado por completo. É interessante destacar que Sartre retoma uma descrição parecida com aquela dos estados em T.E. para falar da transformação ocorrida com o mundo emotivo. Esse mundo, afirma o autor, é tão completo e pleno quanto o mundo dos sonhos, pois através de protensões afetivas, a consciência constitui as qualidades no mundo ad aeternum. Voltando ao exemplo exposto no artigo sobre a Transcendência do Ego, quando eu odeio Pedro, ele não aparece como odioso em tal instante ou em determinado contexto, mas a qualidade objetiva de ser odioso perpetua-se de tal modo que parece ser um atributo substancial de Pedro. Ou seja, 
da mesma forma como o estado era uma transcendência das vivências pontuais de repulsa em T.E., em Emoções, a consciência emotiva recobre o mundo com uma textura emotiva tal que abrange toda a situação vivencial numa síntese individual, no espaço e no tempo. Pedro é odioso como o são suas ações, suas feições, seus trejeitos, e tudo o mais que esteja no horizonte de sua aparição. E todo esse ambiente odioso tende a perpetuar-se no futuro, assim forma-se todo um mundo maciço "Pedro-odioso".

Ainda no contexto da correlação consciência/mundo, é de se supor que não apenas a consciência encanta o mundo, mas, por vezes, é o próprio mundo que já aparece como mágico. Segundo Sartre, esse evento descreve uma segunda forma da emoção, seria aquela das reações bruscas que não solicitam nenhuma conduta e, por isso, aparentam não ter finalidade ${ }^{74}$. Exemplos desse tipo de emoção seriam o horror e a admiração. O notório desses casos é que neles ocorre um movimento contrário àqueles exemplos de emoções sucedâneas de uma ação interditada. Aqui é o próprio mundo que, imediatamente, aparece como mágico. Ou seja, a magia vem do próprio mundo e, portanto, tais emoções revelam uma estrutura existencial mágica inerentemente mundana. Essa dimensão mágica ocorre, sobretudo, nas relações intersubjetivas, já que nelas a consciência se torna, ao mesmo tempo, objeto de outrem e para outrem. Para ilustrar essas emoções peculiares, Sartre cita o horror no caso de um rosto assustador que aparece na janela. O exemplo é simples, estou em um cômodo e surge, de repente, um rosto assustador por trás do vidro da janela; o sentimento de horror toma conta do quarto. O que confere a propriedade mágica dessa emoção - ou seja, a mudança que ocorre no mundo - é o fato de que, para ser efetivo, o horror tem que romper o determinismo encarnado na distância que separa meu corpo de qualquer ameaça real proporcionada pelo rosto. Isso é o que Sartre chama de quebra do mundo dos utensílios. Os utensílios seriam as propriedades determinadas e previsíveis que os objetos ao nosso redor exercem uns entre si e com o todo do mundo. A janela fechada que deve ser aberta, a distância de tantos metros de assoalho que me separa da janela e que deve ser percorrida, esses elementos são os utensílios que, efetivamente, afastam o perigo trazido pela pessoa na janela. Entretanto, a transformação mágica acontece quando esses utensílios de separação se dissolvem e tornam-se, tão somente, a moldura do rosto cuja ameaça afetiva não tem distância. Todo o cenário passa a compor o quadro mágico do horrível. Portanto, neste caso, não é como quando minha consciência

\footnotetext{
74 “Assim, há duas formas de emoção, conforme somos nós que constituímos a magia do mundo como sucedâneo a uma atividade determinista que não pode se realizar, ou conforme é o próprio mundo que se revela bruscamente como mágico ao redor de nós". (SARTRE, 1975, p. 59)
} 
transforma Pedro em ser-odioso para justificar todas as injúrias que ele me causou, o encantamento acontece no sentido inverso; é o mundo, repentinamente e por si só, que se apresenta como magicamente horrível.

Logo depois desse exemplo, Sartre menciona outros aspectos do mundo mágico que soam um tanto quanto enigmáticos:

Naturalmente, a magia como qualidade real do mundo não é estritamente limitada ao humano. Ela se estende às coisas na medida em que estas podem se apresentar como humanas (sentido inquietante de uma paisagem, de certos objetos, de um quarto que conserva o vestígio de um visitante misterioso) ou trazem a marca do psíquico. (SARTRE, 1975, p. 5960)

As fórmulas são misteriosas, mas revelam aspectos dos mais interessantes dessa teoria do mundo que se auto apresenta como mágico. Como o autor explicita, trata-se sempre de humanização das coisas. Nossa vida cotidiana está repleta de exemplos de como a consciência capta o mundo ao redor num aspecto humanizado. A própria percepção visual tende a organizar as formas e objetos na proporção do ser humano, o fenômeno da pareidolia revela essa tendência. Através desse processo, buracos da tomada e rochas em Marte se tornam rostos, nuvens se convertem em objetos do cotidiano, animais e assim por diante. Ou seja, mesmo na experiência que consideramos como a mais objetiva, a da percepção, a consciência tende a colocar filtros humanos no mundo. Mas a teoria sartreana vai além, quando o mundo se releva como mágico, os objetos não se revelam apenas morfologicamente humanos, mas também afetivamente. "O sentido inquietante de uma paisagem", esse inquietante trata-se, certamente, de um tipo bastante fino de emoção, mas também ele pode ser exemplificado em experiências quotidianas. Ruínas de pedra na selva cambojana, geoglifos no deserto de Nazca, um parque de diversões deserto no leste europeu, hospitais psiquiátricos abandonados, enfim, todos esses cenários que costumam compor histórias de mistério, aventura ou terror, só são tão recorrentes na cultura popular porque possuem, por si sós, a capacidade de gerar inquietações e arrepios sutis. Onde quer que a presença humana tenha tocado, um sentido afetivo latente restará pronto para ser apreendido por qualquer consciência. No entanto, essa estrutura existencial mágica do mundo é mais um dos temas que Sartre promete desenvolver em outra parte, cuja teoria constituída não viu a luz do $\operatorname{dia}^{75}$. Ainda assim,

\footnotetext{
${ }^{75}$ Idem, ibidem p. 58.
} 
esse mero esboço do segundo tipo de emoção já serve para embasar mais ainda a constituição do mundo mágico da emoção.

A partir de tudo o que foi exposto, pode-se apresentar a definição mais completa da emoção, definição que serve para todos os casos apresentados até aqui: a emoção é o rompimento do mundo determinado dos utensílios e a subsequente queda no mundo mágico. Dada essa definição, Sartre salienta o que vinha defendendo desde o início do esboço das Emoções, a emoção não é uma modificação acidental de uma subjetividade num mundo que permaneceria inalterado, ao contrário, é uma forma organizada através da qual a consciência altera todo o seu mundo de uma só vez. Ela é, portanto, uma reorganização total do mundo, desfazendo o caráter utensílio das coisas, unindo-as todas num todo sintético tingido pela mesma cor emotiva - assim, no caso do rosto na janela, todos os objetos ao redor aparecem com a mesma textura de horrível; tudo emoldura e compõe o quadro mágico do horror.

Portanto, o sentido do mundo da emoção é constituído pela consciência. Mas é preciso reiterar, não se trata de uma brincadeira, de um faz de conta - como quando a imaginação das crianças transforma cabos de vassouras em espadas e armários em fortalezas - é um mundo levado a sério pela consciência, nele ela vive e fica cativa. Como Sartre afirma, desde a descrição do psíquico em T.E., a consciência sofre seus estados emotivos. Já foi afirmado acima (no exemplo das uvas inalcançáveis e do videogame difícil) que a conduta confere seriedade à emoção. Ou seja, não se pode ignorar o envolvimento do corpo na vivência emotiva. O problema com as psicologias positivistas criticadas no capítulo anterior é que elas consideravam apenas o corpo, mas Sartre pretende levar em conta as manifestações fisiológicas na exata medida em que elas revelam o sério pelo qual a subjetividade vive a emoção. No entanto, o autor salienta que a emoção não se restringe à sua conduta. Para ilustrar isso, ele cita o caso de condutas puras que expressam falsas emoções (quando uma pessoa finge gostar de um presente), ou até mesmo imitações de emoção (o caso de um ator). A verdadeira emoção não se esgota em sua conduta, pois ela é acompanhada de crença; ela é sofrida pela subjetividade. É por essa razão que, nas críticas ao psicologismo, Sartre afirma o caráter vão de um estudo isolado dos fenômenos fisiológicos. Eles formam um todo sintético com as condutas, "representam o sério da emoção" (idem, ibidem p. 52), entretanto, nada podem explicar sobre a dimensão subjetiva, ou seja, o sofrido da emoção. Para a compreensão dessa dimensão subjetiva, deve-se levar em conta o fator de crença da consciência. Em 
outras palavras, o modo como a consciência vive a significação afetiva que ela projeta no mundo. Assim, a vivência no corpo traduz a crença da emoção, mas, por si só, ela é como a febre para uma doença, quase que um mero sintoma externo que nada pode dizer sobre o vírus ou a bactéria que ataca o corpo.

A partir de tudo o que foi dito, Sartre destaca dois pontos que merecem ser ressaltados, mesmo que já estejam subentendidos:

1. A consciência emotiva não é tética: Ou seja, imediatamente, a consciência não se percebe a si mesma degradando-se e ressignificando o mundo. Assim, a carga afetiva é vista como uma qualidade objetiva desse novo mundo que surge. Mas, isso não significa que a finalidade da emoção seja inconsciente. Sendo consciência não posicional de si, a consciência emotiva constitui a finalidade junto com o próprio objeto da emoção, e nessa mesma constituição ela se esgota.

2. A consciência emotiva é cativa: Justamente por transcender-se no mundo, a consciência vive nele. Sem o caso especial da reflexão, ela nunca está voltada para si. Isso significa que a consciência vai viver seriamente o mundo mágico que cria. Dessa forma, pode-se afirmar que ela é cativa de sua própria magia e, não obstante, é sempre o mundo que lhe aparece como cativante. Sem a intervenção da ação reflexiva, a consciência tende a perpetuar o mundo mágico e, consequentemente, a emoção. Sendo assim, a emoção só pode dissipar-se em duas circunstâncias: com uma reflexão purificadora, ou com o desaparecimento da própria situação emocionante.

Com essas colocações, encerra-se a descrição do maciço e sinteticamente contínuo mundo mágico da emoção. Um conteúdo considerável da primeira parte desta pesquisa destinou-se a mostrar que o ser do mundo objetivo independia completamente da consciência. Em outras palavras, a existência das coisas se impunha a nós, presente e absoluta; o ser nada devia ao conhecer. Agora, nesta segunda parte da dissertação, vemos a contraparte dessa tese; a consciência, por seu lado, desconhece a causalidade por parte do mundo físico. O seu ser se constitui a partir de uma liberdade radical que é capaz de constituir o sentido de suas próprias vivências. Sendo assim, embora a consciência não possa nada frente ao ser do mundo - além de testemunhar sua presença - ela pode viver nesse mundo de uma maneira que escapa a qualquer determinismo. Um dos modos desse 
viver é transformando o sentido desse ser cuja presença a preenche de parte a parte. Se atribuirmos todas essas constituições de sentido ao poder da intencionalidade, podemos compreender aquela outrora misteriosa afirmação de Sartre de que Husserl restituíra o mundo dos artistas e dos profetas ${ }^{76}$. O mundo deixa de ser um amalgama de matérias mortas, de seres estáticos e desinteressantes (aquelas carnes nauseantes que tocavam Roquentin), e se torna o horizonte dos projetos humanos, de formas estéticas, de criaturas afetivas, mesmo de relações e proporções matemáticas como na visão de Galileu; todas essas qualidades não são senão um modo absolutamente humano de apreender seu entorno. Ora, na medida em que a consciência emocional retorna - a todo momento e na maioria das vezes irrefletidamente - ao mundo, ao ponto de não apenas se perder nessa imersão, mas a transformá-lo, reinterpretando e redefinindo suas relações, encantando-o, vemos que o mundo está, a todo instante, tingido pelas cores da consciência. As infinitas qualidades que possamos conceber - belo, terrível, atraente, assustador, repugnante - na atitude habitual de nossas vidas não são vistas como reações subjetivas, mas como qualidades objetivas. O mundo está impregnado das vivências e dos modos existenciais humanos. Assim, a Noite Estrelada não se trata de tintas e texturas numa tela, mas era a própria experiência vivida por Van Gogh numa noite no sul da França; magicamente, o próprio céu podia rodopiar, é por isso que uma tela pintada pode cativar estética e afetivamente qualquer pessoa. Mesmo a aridez imagética da flor amarela de Alberto Caeiro, só podia ser essa coisa plana e neutra do mundo, porque assim um poeta a enxergava na beira do rio. Enfim, “É uma qualidade dessa máscara japonesa ser terrível (...) e não a soma de nossas reações subjetivas a um pedaço de madeira esculpido",77. $\mathrm{O}$ que Sartre quer dizer aqui é que a intencionalidade, ao mesmo tempo em que nega o solipsismo, também reafirma a validade do mundo intersubjetivo e suas formas humanas, pois o mundo não é um correlato meramente epistemológico, mas também o é afetivo e semântico da consciência.

\footnotetext{
${ }^{76}$ SARTRE, 2003a, p. 89.

${ }^{77}$ Idem, ibidem.
} 


\subsection{Ser-no-mundo: adentrando no existencialismo.}

Mas o que pode valer a vida, se o primeiro ensaio da vida, já é a própria vida. (Milan Kundera, A insustentável leveza do ser)

\subsubsection{Finalidade; espessura temporal da consciência.}

A ligação da consciência com a temporalidade já estava implícita desde a exposição que a apresentava existindo num fluxo de retenções e protensões. O problema com os textos anteriores a $E$. era o critério de validação da evidência, que só podia ser adquirido através da reflexão pura. Como vimos, essa reflexão estava limitada ao instantaneísmo, a um presente congelado cuja relação com seu passado era ininteligível, é daí que vinha a necessidade do recurso ao ex nihilo para descrever o aparecimento da consciência. Como pretendi ter demonstrado na seção 4.1.2. deste capítulo, a ideia do tema diretor que comandava as ações já dava a entender que sucessões ex nihilo, independentes umas das outras, não poderiam dar conta de descrever o funcionamento de uma consciência engajada em projetos complexos como as ações. Agora, com a consideração do psíquico fenomênico e da protensão emocional, finalmente essa extensão temporal que dá sentido ao plano de ações, pode ser captada também como um fenômeno de consciência, já que está contida na apreensão imediata e irrefletida de um objeto emocional. Esse tema da finalidade da emoção, e sua consequente temporalização da consciência, parece resolver muitas das dificuldades teóricas que esta dissertação deixou em aberto nas páginas anteriores. Sendo assim, dedicarei as próximas páginas para analisar com mais atenção esses desenvolvimentos conceituais.

O termo que mais explicita a implicação da temporalidade na teoria das emoções de Sartre é a expressão “protensões afetivas”. Na explicação sobre o mundo da emoção, vimos que o sentido afetivo constituído pela consciência não é pontual, não se aplica apenas a uma parte destacada da realidade. No exemplo do rosto na janela, todos os utensílios se convertem na moldura do horror; a qualidade "horrível" tinge todo o contexto em que o objeto que a suscitou se encontra. É essa extensão absoluta que permite falar num mundo maciço da emoção. Em T.E. já se afirmava que, ao conferir qualidade às coisas, a consciência o faz ao infinito. Em Emoções, Sartre mantém esse ponto de vista com a grande diferença - como veremos - de que agora essa passagem ao infinito não se tratará de uma extrapolação a ser exorcizada pela reflexão pura. É de se supor que essa passagem ao infinito ocorre, também, temporalmente. Excetuando o caso de que o rosto 
na janela fosse apenas meu amigo Pedro me pregando um susto - neste caso a consciência da emoção, num átimo de segundo, perceber-se-ia enganada e desaparecia junto com o fato de Pedro não ser horrível - o sentimento e, portanto, o sentido de horror permaneceriam por todo o tempo em que o rosto continuasse lá, pois no mesmo instante em que o vê, a consciência apreende nele o horrível como propriedade permanente. Conforme nota-se nesta passagem que merece ser citada:

Ora, toda qualidade só é conferida a um objeto por uma passagem ao infinito (...) as qualidades que a emoção confere ao objeto, ela o confere ad aeternum. Por certo, se percebo bruscamente um objeto como horrível, não afirmo explicitamente que ele permanecerá horrível para sempre. Mas a simples afirmação do horrível como qualidade substancial do objeto já é, nela mesma, uma passagem ao infinito. Agora o horrível está na coisa, no coração da coisa, é sua textura afetiva, é constitutivo dela. Assim, através da emoção, uma qualidade esmagadora e definitiva da coisa nos aparece. E é isto o que ultrapassa e mantém nossa emoção. O horrível não é apenas o estado atual da coisa, é ameaça quanto ao futuro, estende-se por todo o porvir e o obscurece, é revelação sobre o sentido do mundo. Assim, em cada emoção, uma série de protensões afetivas dirige-se ao futuro para constituí-lo sob um aspecto emocional. (SARTRE, 1975, p. 56)

Essa protensão afetiva significa que a consciência estica sua vivência num futuro indeterminado. Do mesmo modo como a consciência perceptiva adianta aspectos do mundo, completando lacunas sensoriais e antecipando vivências - o que fez com que, segundo a anedota, Husserl cumprimentasse uma boneca de cera na rua, tomando-a por uma pessoa - a consciência emotiva adianta a continuidade das qualidades do mundo, e é isso o que permite com que ela construa um projeto na sua relação com esse mundo. Em outras palavras, falar sobre a finalidade da consciência é admitir a sua projeção temporal no futuro.

Para ilustrar essa tese, Sartre apresenta alguns exemplos do finalismo atuante em certas emoções:

- O medo passivo (desmaio): tentativa de fazer o objeto da emoção desaparecer, suprimindo a própria consciência.

- O medo ativo (fuga): não se trata de uma atitude refletida de autopreservação para salvar-se, por exemplo, de um predador. Trata-se de uma tentativa de fazer o objeto terrível desaparecer, movendo o próprio corpo para longe dele. - É notável que os dois tipos de medo, para Sartre, são tentativas de suprimir o objeto.

- Da tristeza passiva (recolhimento): tentativa de neutralizar o mundo, torná-lo menos afetivo, indiferenciado, para assim anular suas exigências. 
- Da tristeza ativa (crise nervosa de choro): tentativa de tornar o objeto, ou a ação a ser realizada, humanamente impossíveis, a fim de justificar nossa incapacidade frente a eles.

- Da alegria: Sartre diferencia o que ele chama de alegria sentimento e alegria emoção, esta última seria o conjunto das ações eufóricas (dançar, pular, bater palmas) frente a algo bom (ganhar na loteria, saber da visita de um amigo). Essa emoção seria, na verdade, uma certa impaciência frente à impossibilidade de fruição instantânea do objeto desejado. Sendo assim, ela é uma conduta que tenta realizar magicamente o usufruto que só pode ser consumido aos poucos.

Em todos esses casos, vemos claramente a presunção de um futuro a se realizar no mundo, e a ser realizado pela consciência. A emoção em todos esses casos é a constituição de uma qualidade no mundo com a finalidade de, a partir dela, executar-se certa conduta, de acordo com certo projeto. Ora, essa protensão afetiva, essa projeção da consciência rumo ao futuro, jamais seria aceita como parte da imanência da consciência conforme a descrição de T.E., era isso o que previa o critério de evidência da reflexão pura. Nesse artigo, os temas diretores que regiam a dinâmica das ações eram identificados do lado do psíquico que, como lembramos, ficava numa esfera completamente distinta daquela da consciência transcendental alcançada pela reflexão fenomenológica. $O$ psíquico era o objeto transcendente da consciência transcendental e objeto de estudo dos psicólogos. Campos de ser diferentes, diferentes abordagens de estudo. No entanto, em Emoções e mesmo nos livros sobre a Imagem, Sartre não propõe outra coisa senão uma psicologia fenomenológica. Em outras palavras; a possibilidade de um estudo fenomenológico do objeto da psicologia (o psíquico). Ou seja, Sartre está buscando o eîdos, a essência do fato psíquico. A manifestação psíquica também é um fenômeno, isso significa que o critério rigoroso de evidência da reflexão pura não é mais utilizado, e isso ocorre, por sua vez, porque a própria concepção de fenômeno de consciência foi alterada.

Neste ponto, acompanho a leitura de Moutinho $^{78}$ segundo a qual, a procura por esse eîdos do psíquico constituirá um meio termo entre a passagem do perfeitamente adequado da imanência (repulsa por Pedro) para o incerto do sentido transcendente (ódio por Pedro). Tal meio termo não existia em T.E. de modo que, agora, o eîdos funcionará como uma ponte entre o domínio de estudos da filosofia e o da psicologia. Será preciso,

\footnotetext{
${ }^{78}$ MOUTINHO, 1995b, capítulo 3.
} 
pois, realizar dois tipos de reduções; fenomenológica e eidética, respectivamente para cada domínio (consciência transcendental e psíquico) ${ }^{79}$. E o que vem a ser esse eîdos, essa essência do fato psíquico da emoção, já o sabemos; a maneira como a emoção significa o todo da realidade humana. Sendo assim, à psicologia fenomenológica caberá estudar a emoção significante. Ou seja, como a consciência constitui a finalidade de suas condutas afetivas. Portanto, não se trata de buscar o significado particular de tal ou tal emoção, mas sim como é constituído o processo de significação no ato emocional, pois essa constituição de sentido é a essência do fato psíquico emoção.

Esse tipo de estudo, portanto, concebe o ser psíquico como um fenômeno. Ou seja, o ser psíquico não é mais, meramente, um objeto constituído pela consciência transcendental, ele também passa a ter um papel constituinte no que se refere ao sentido de suas emoções. Além disso, é na medida em que o psíquico passa a ser considerado como fenômeno que é possível conferir temporalidade à consciência, pois ele é regido por "temas diretores" que, necessariamente, extrapolam os limites do instante ${ }^{80}$. Essa é uma perspectiva ausente em T.E. Agora o psíquico não é mais um mero objeto passivo da consciência, ele é - assim como a percepção e a imaginação - uma forma pela qual ela existe no mundo. E essa forma de existência é temporal, o que representa um importante avanço conceitual, pois resolve todos aqueles impasses apontados pela dificuldade da ligação entre consciências instantâneas surgidas ex nihilo.

Essa é, pois, a importância da ideia de "tema diretor" que orienta a ação numa conduta emotiva; mesmo que tal ideia não tenha sido devidamente elaborada e acabada, ela aponta para consequências teóricas deveras relevantes. Admitir a finalidade não significa temporalizar apenas a consciência, mas a própria noção de fenômeno que em T.E. significava apenas translucidez. É dessa forma que "Também passa a valer para ele (o psíquico) - e na perspectiva da psicologia eidética - a equação segundo a qual 'a realidade é precisamente a aparência' (id., ibid., p. 15)" (MOUTINHO, 1995b, p. 100). Essa espessura temporal da consciência, apesar de que só será de fato tematizada e trabalhada em $O$ Ser e o Nada, desde aqui já indica os primeiros passos da concepção existencialista da subjetividade que existe na forma dos projetos de si que se transcendem

\footnotetext{
${ }^{79}$ MOUTINHO, 1995b, p. 99

80 Já que todo tema diretor aponta para uma finalidade, portanto para um futuro presumido. Sendo assim, esse conceito só pode fornecer coesão e sentido para várias consciências sucessivas, conquanto as unifique num fluxo temporal.
} 
e ultrapassam o mundo. Um projeto só pode existir no tempo, portanto é apenas com a temporalidade que a consciência pode constituir seu engajamento, transcorrendo e superando os limites de sua situação.

\subsubsection{A insustentável leveza do ser-no-mundo.}

A conclusão que podemos tirar dos livros sobre psicologia fenomenológica é que a consciência possui diferentes formas de "ser-no-mundo". Estamos acostumados a considerar majoritariamente a forma mais “objetiva”, quase que limitada à percepção, que é aquela na qual o mundo aparece como um conjunto determinado e infinito de utensílios. Nesse modo de ser, as alterações que a consciência pode imprimir no mundo são sempre parciais e localizadas, e a modificação de cada utensílio em particular sempre depende da alteração de algum outro, que remete para outro e assim por diante, como ocorre no sistema metafísico de Espinosa. Mas, nos modos de ser imaginativo e emocional, a consciência supera as arestas estreitas da realidade para, afirmando sua liberdade ontológica, realizar transformações maciças do seu mundo ambiente, leia-se, da sua situação. Claro que, como já foi ressaltado, num ponto de vista objetivo, a liberdade para

ultrapassar o real pode flertar com a alienação. É por isso que, após o desenvolvimento de sua ontologia, a filosofia sartreana demanda uma ética que lhe seja subjacente. Mas, como sabemos, um tratado ético ou moral nunca foi desenvolvido pelo filósofo, de modo que nos resta, apenas, conjecturar nesse sentido - esse foi o objetivo que permeou todo o corpo desta dissertação e que ainda renderá estes últimos comentários.

Na primeira parte desta dissertação, o estudo da intencionalidade mostrou que, para a consciência, ser significa ser-no-mundo. Ora, esta segunda parte se dedicou a mostrar, através da crítica ao psicologismo determinista, as formas pelas quais a consciência pode ser-no-mundo. De fato, vimos que existe mais de uma maneira pela qual isso acontece, mas o que une todas essas formas? É aquilo que Beauvoir chamava de "soberania da consciência" quando falava do projeto sartreano conforme citei nas primeiras páginas deste texto. Esse termo "soberania" pode ser lido através de vários sentidos, mas acredito que a acepção mais geral "autodeterminação" pode concordar com todos. Ora, esses vocábulos precisam ser lidos com algum cuidado. Da mesma forma como em filosofia política os termos "soberania" e "autodeterminação" renderam muitas 
acusações de ingenuidade saudosista para Rousseau ${ }^{81}$, também Sartre foi vítima de muitas más interpretações devido à sua concepção de liberdade da consciência. Já tentei desfazer algumas delas quando mostrei que a ação, para o filósofo francês, não significa voluntarismo. Mas, agora, ainda cumpre especificar positivamente o que a descrição fenomenológica encontrou como liberdade.

A expressão ser-no-mundo já indica muita coisa. Na primeira parte desta pesquisa, demos atenção para "no-mundo", mostrando que a consciência nunca pode ser concebida de forma isolada de sua situação mundana. Não sendo um espírito e nem uma substância pensante, o estatuto ontológico da consciência intencional redundava em recusa do solipsismo e em engajamento. Agora, podemos entender também o que significa o verbo “ser". Como sabemos, Sartre formulou com cuidado a expressão être-au-monde (ser-nomundo), de maneira a não a confundir com être-dans-le-monde (ser-dentro-do-mundo). A consciência não existe no mundo como uma pedra, ou outro objeto qualquer que embora esteja sujeito à causalidade de seus pares e, com isso, possa sofrer mudanças de formato ou qualidade - permanece estático no estatuto de seu ser. Como vimos, as coisas em si apenas são. Aquela pedra, independentemente das alterações as quais suas qualidades sensíveis estão suscetíveis, em relação à sua existência ela apenas é ${ }^{82}$. Já a consciência, ela nunca é, ela vem a ser, sua existência ocorre na forma da ação expressa pelo verbo "ser". É por isso que sua forma de existência é chamada de para si; ela se coloca a todo instante como uma questão para si mesma ${ }^{83}$. Ora, neste sentido, o que significa a afirmação de que a liberdade não é um atributo, mas sim uma determinação ontológica da consciência? Bem, se essa pedra é dura ou macia, se está íntegra ou rachada, se é bege ou preta, não importando sua qualidade, ela sempre é. Por isso, posso determinar e estabelecer cada uma de suas qualidades. Entretanto, um ser que não é precisamente nada, nunca pode ser determinado. Como uma partícula subatômica no princípio de incerteza, também a consciência nunca pode ser observada e definida ao mesmo tempo ${ }^{84}$.

\footnotetext{
81 Apenas a título de menção, veja-se a crítica de Benjamin Constant que afirma que o conceito rousseauniano de liberdade, na forma de exercício da soberania, seria apenas uma tentativa anacrônica de reproduzir a liberdade política vivida pelos antigos, para sempre perdida às sociedades modernas.

82 Sendo dura, rachada, cinza, branca, etc., a pedra continuará sempre sendo algo predicável, seu estado sensível atual, não importa qual seja, será sempre, existencialmente, inerte.

${ }^{83}$ Ver seção 3.1.1. desta dissertação.

${ }^{84}$ Objetivamente, ela já não pode ser observada por princípio, uma vez que se trata de imanência e não transcendência. Internamente, ela jamais pode ser aquilo que observa, pois quando observa, ela é observadora que não coincide mais com aquilo que é observado. As explicações sobre a diferença entre a consciência reflexiva e refletida não queriam dizer outra coisa. A consciência nunca pode se ver sendo nada, pois quando se vê sendo x-visado, ela já se transformou em y-vidente. É um ser que, angustiosamente,
} 
Esta é a base para a formulação conhecida de O Ser e o Nada segundo a qual o para-si é aquilo que ainda não é e não é aquilo que é. Sendo assim considerada, a soberania da consciência já não parece tão romântica. Não se trata da propriedade de, por nunca sofrer causalidade, poder ser qualquer coisa que se queira ser. Mas sim de, arrebatada por um grande vento, nunca poder se abrigar em nenhum refúgio que confira estabilidade ao seu ser. É por isso que essa liberdade vertiginosa será lida pelo existencialismo como angústia. Ora, aqui temos que concordar com Milan Kundera que a extrema leveza da indeterminação de um einmal ist keinmal ${ }^{85}$ o torna, paradoxalmente, mais pesado que a absoluta definição do es muss $\operatorname{sein}^{86}$.

A oposição entre o modo do ser em si e do para si forma um emaranhado ontológico mais complexo do que uma mera dicotomia dual. Na medida em que o para si não sofre nenhuma determinação por parte do mundo, ao mesmo tempo em que confere todo o sentido desse mundo, forma-se uma equação complicada, na forma de dupla antinomia: Por um lado temos o mundo do ser em si - determinado, mecânico - que é apreendido pelo para si - indeterminado, imprevisível. Mas nesse mesmo ato de apreensão, a consciência constitui o sentido do mundo de acordo com um projeto finalista, assim temos; a realidade humana - organizada e significativa - que se torna uma antípoda da existência do em si - acidental e contingente. Portanto, quando a consciência é considerada segundo as determinações de seu ser, ela é um nada indefinido, oposto a um mundo regido por leis mecânicas, mas referenciada a um projeto, a teoria da ação/emoção em Sartre é um teleologismo e não um determinismo psicológico, assim a consciência se mostra como um ser organizado frente a um mundo gratuito. Portanto, a definição da consciência enquanto liberdade ontológica, ao mesmo tempo em que gera angústia por conta da instabilidade de seu próprio sentido, também sugere o poder de dar sentido para seu mundo, organizando seu projeto de ser. Sem sentido de ser, a consciência é soberana para dar sentido ao ser. No vocabulário existencialista, esta última frase ficaria "a existência precede a essência". Eis, portanto, a condição da existência humana; uma existência radicalmente indeterminada e, portanto, livre para definir escolhas e projetos no mundo, e, exatamente por isso, angústia pela abstinência de sentido do seu próprio ser e uma responsabilidade, mais pesada do que o mundo, por suas escolhas. Todas essas

está sempre se colocando a ser, sempre para si mesma, e sempre malogrando neste intento de ser algo, pois quando é, já não é mais.

${ }^{85}$ Tradução livre do alemão: "uma vez é nunca".

${ }^{86}$ Tradução livre do alemão: "assim tem que ser". 
constatações foram constituídas pela maneira como Sartre leu a fenomenologia de Husserl. É assim, portanto, que a epistemologia endossa uma ontologia que, por sua vez, aponta para uma ética radicalmente nova em relação a tudo o que já havia sido feito. Toda moral e toda ética sempre dependeram de uma régua de valores, fossem esses valores universais ou absolutos, eles sempre eram dados de antemão; a moral tratava-se do seguimento à risca de regras racionais, religiosas, etc. Quando a consciência é ontologicamente descrita como um vazio, uma indeterminação absoluta constituída unicamente por sua atividade de encontrar e constituir sentido ao mundo, então a ambição ética perde todo solo sólido em que se firmar e encontrará conteúdo unicamente na maneira como coloca a própria existência. Com essa tese, o caminho do existencialismo está em aberto. A fenomenologia, portanto, foi para Sartre muito mais do que a chave teórica para liquidar com a antiga querela epistemológica entre idealismo e realismo, ela foi a metodologia que endossou os caminhos para uma ética cujos únicos imperativos são uma liberdade absoluta e sua própria assunção; é o fim do moralismo e o início da constituição da autenticidade existencial. 


\title{
Conclusão
}

\begin{abstract}
A vida que procuras, não a encontrarás: quando os deuses fizeram o homem, dispensaram-lhe a morte, mas a vida retiveram para si mesmos. Por conseguinte, Gilgamesh, enche a barriga, dia e noite rejubila nas coisas, faz de cada dia um dia de festa, dança e goza dia e noite! Estejam limpas as tuas roupas, lavada a tua cabeça, que te possas banhar em água! Abisma-te na criança que levas pela mão! Deleite-se a tua mulher no teu abraço repetido! É esse o destino dos mortais (...) (O Épico de Gilgamesh)
\end{abstract}

Vimos que as obras de Sartre da década de 1930 - apesar de abordarem temas distintos como o conceito husserliano de intencionalidade, a negação do Ego e temas psicológicos sobre a imagem e a emoção - formam um todo coerente. O que confere unidade para essa variedade temática é, acredito, o projeto de constituir uma teoria da consciência que assegure, ao mesmo tempo, a presença da realidade objetiva e a autonomia da subjetividade. O conceito que dá sustentação para essa teoria é a consciência intencional. Como vimos, esse conceito é aprimorado e enriquecido ao longo das obras estudadas, mas guarda sempre os principais caracteres de ser um ente voltado para o mundo, num movimento absolutamente indeterminado e, portanto, livre. Consequentemente, a consciência em Sartre é menos um ser (no sentido de algo que possa ser definível) e mais uma ação. Seria temerário afirmar, desde aqui, que as obras sartreanas desse período formam um esboço de ontologia. Ainda assim, acredito que a passagem da psicologia, para a ontologia fenomenológica de $O$ Ser o Nada, a despeito da descontinuidade temática, não se trata de uma ruptura brusca, pois são temas diferentes trabalhados num mesmo projeto. A psicologia fenomenológica desenvolvida desde T.E até $E$. constitui a fundamentação teórica do grande livro dos anos 40 . O recorte desta pesquisa não constrói, porém embasa a ontologia existencialista, através da definição da consciência e sua relação com o mundo que é desenvolvida nessas obras. O que motivou esta pesquisa foi a busca por aquilo que impulsionou todo esse projeto teórico do jovem filósofo; um ímpeto ético que tomou forma com a constituição de uma teoria sobre a condição humana. Em relação a esse ímpeto, acredito ainda ser possível fazer as próximas, e últimas, considerações.

Por que fez sentido nossa exposição da crítica à psicanálise (frequentemente ignorada pelos comentadores) no terceiro capítulo? Porque, embora ela esteja num terreno metodológico muito diferente daquele das críticas às psicologias positivistas, ela compartilha com estas últimas um objetivo central de Sartre; resguardar a autonomia da consciência frente a qualquer sistema mecânico de causalidade. Nos positivistas, essa 
causalidade exterior vinha do corpo, na psicanálise, embora seja subjetiva, a causalidade advinda do inconsciente continua sento tão exterior quanto mecânica. Portanto, a grande oposição ao mecanismo não é, meramente, o subjetivo (quer dizer, um estado psíquico determinando outro estado psíquico), mas sim o finalismo, e esse finalismo perde seu sentido se não for constituído soberanamente pela consciência, durante o próprio ato de vivenciar o mundo. É exatamente esse poder de constituição que confere à consciência pré-egológica as determinações de um sujeito conforme vimos no quarto capítulo. E qual é a importância dessa crítica ao mecanicismo? O que está em questão é a própria dinâmica da existência humana no mundo. Ora, o ser em si está sempre condenado a ser aquilo que é, nunca se coloca, sempre é colocado, todas as suas ações e transformações ocorrem no sistema da causalidade. A causalidade determina as interações entre seres passivos. Já a consciência - e, portanto, a subjetividade - uma vez que é sempre o exterior de si mesma, impredicável e indefinível, não pode ser classificada dentro desse sistema causal. A finalidade da emoção mostra isso; a ação da consciência nunca pode ser lida através de uma causa que lhe tenha determinado previamente, mas sim pela motivação que lhe movimenta rumo ao futuro. Portanto, não há desculpas, somos nosso próprio projeto de ser, embora não possamos escolher a situação da qual partimos - já que a realidade independe e é anterior ao ser cognoscente, tudo o que fazemos do que fazem de nós é sempre uma escolha, motivada e movida por projetos livres ${ }^{87}$. Por essa razão, a atitude antiética por excelência segundo o existencialismo, a má-fé, vem a ser a pretensão do ser para si em tomar os contornos do ser em si; acomodar-se na passividade de ser aquilo que se é determinado a ser. A responsabilidade da vida humana é sempre uma questão de assunção da própria existência. Todas essas questões são, de fato, alheias às indagações de uma epistemologia pura, que estariam limitadas aos questionamentos sobre a natureza do conhecimento. Uma vez que a filosofia de Sartre desde seu início aponta para tais consequências teóricas, podemos afirmar que sua fenomenologia foi, desde sempre, uma fenomenologia engajada, pois sempre quis extrapolar a teoria do conhecimento para adentrar no terreno da vida prática.

\footnotetext{
${ }^{87}$ Essas questões colocadas pelo existencialismo irão repercutir em diversas áreas do conhecimento e da ação humana. Notadamente, a abertura indeterminada da consciência à existência é um tema de grande interesse para a psicanálise e, mesmo, para a psiquiatria contemporânea. Podemos ver reverberações dessa teoria, por exemplo, no pensamento do psiquiatra alemão Thomas Fuchs "Os homens não vivem apenas, mas conduzem sua vida, e, com isto, eles a moldam por si mesmos, eles configuram por meio de suas decisões e ações o seu próprio desenvolvimento (...) Naturalmente, essa abertura também traz consigo múltiplas possibilidades de perturbação, e, em verdade, de início uma disposição particular para a angústia, uma das formas mais frequentes de manifestação de transtornos psíquicos" (FUCHS, 2018, p. 11).
} 
O que pode, afinal, ser predicado desta fenomenologia peculiar? Nos limitaremos à leitura vulgar do existencialismo que considera apenas o desamparo do ser-humano, largado num mundo gratuito, sem nenhuma régua moral preestabelecida? Apesar de certo desamparo bibliográfico, prefiro responder que não. Uma filosofia como a de Sartre, que teve seu próprio início impulsionado por pretensões morais, não pode terminar em aporia em relação ao tema “o que fazer de nossa existência?”. Não por acaso, iniciei esta dissertação apresentando o anedótico encontro do Bec de Gaz. Como lá disse, e agora repito, os motivos que fizeram Sartre se empolgar com a fenomenologia, por si só, já dizem muito sobre a teoria fenomenológica desenvolvida pelo autor. Ora, Raymond Aaron não fez seu colega empalidecer (ou quase) de emoção porque a fenomenologia seria uma filosofia logicamente rigorosa, estilisticamente elegante ou conceitualmente irrefutável, mas sim porque ela ia de encontro às ambições do jovem filósofo. Essas ambições, lembramos, podiam ser resumidas em superar a oposição entre idealismo e realismo. Mas, para Sartre, esse debate não se tratava de uma mera disputa epistemológica, seu objetivo era notadamente moral; combater, ao mesmo tempo, o quietismo contemplativo sugerido pela metafísica idealista e a reificação tacitamente legitimada pelo realismo metafísico. Portanto, em última instância, era sobre a ação e a vida humana que os interesses filosóficos de Sartre pairavam. Foi por isso que a sobriedade austera de obras como As Investigações Lógicas e Ideias I, fizeram nascer um comentário que terminava por declarar possibilitada a fundamentação filosófica de uma moral e de uma política absolutamente positivas ${ }^{88}$.

Podemos, agora, visualizar o resultado alcançado pela empresa iniciada com a ida a Berlim no ano seguinte ao encontro no Bec de Gaz. Uma vez que a metafísica idealista esteja refutada pelo conceito de intencionalidade, a vida é identificada com a soma de nossas atividades executadas nas instituições, praças, bares, escolas, enfim, em tudo aquilo que não seja imersão subjetiva. Não se trata, aqui, de condenar o recolhimento reflexivo. Mesmo o matemático que está a dias confinado no quarto, entretido com seus cálculos, pode ser considerado alguém que vive o mundo, na medida em que, intencionalmente, os números são seres objetivos que contribuirão para a ciência. A imersão ontológica no mundo chama atenção para o sentido de nossas experiências, para o fato de que somos uma vida acoplada ao seu meio, ativa, enfim, engajada. Além disso, a própria identidade pessoal é identificada com o fruto das relações interpessoais (em suas

\footnotetext{
${ }^{88}$ SARTRE, 2003b, p. 131.
} 
últimas obras de biografia existencial, Sartre chamará a subjetividade de universal singularizado), ou seja, não é possível conceber a existência do Eu sem aquela do Tu, do Nós e do Eles(as) ${ }^{89}$. Sendo assim, contraparafraseando Margaret Thatcher: "Não existe essa coisa de indivíduos, o que existe é o mundo intersubjetivo que se singulariza". As implicações de uma tal tese para a conduta empática são incalculáveis.

Quanto à refutação do realismo metafísico, traduzida na crítica à psicologia positivista, ela também traz conclusões bastante interessantes. Transcendendo, via intencionalidade, a emoção no mundo, fazendo dela uma atitude e não um estado passivo e subjetivo, Sartre estabelece uma nova perspectiva a partir da qual nos relacionamos uns com os outros e com o mundo. Contra o mundo desencantado das ciências, Sartre estabelece um mundo onde um pedaço esculpido de madeira se torna um rosto terrível, não porque eu seja subjetivamente assustadiço, mas porque seus olhos estão arregalados, seus dentes são pontudos e sua pele é vermelha. Pelo mesmo processo, existem as imagens sacras, é porque a intencionalidade exterioriza o sentido das coisas que posso dizer que uma imagem da virgem Maria, de Iemanjá, ou de Buda, são objetos sagrados e, entretanto, aquelas estátuas de Zeus, Annubis ou os altos-relevos de Shamash e toda a miríade de Anunnakis não têm mais santidade. Esse último conjunto de ídolos é tão somente uma coleção de peças arqueológicas de museus, pois é isso que sua antiguidade e seu culto morto oferecem para as consciências que os apreendem, ao passo que as primeiras imagens citadas ainda são animadas pela intencionalidade de seus crédulos. Ao constituir sentido, a consciência também confere vida ao mundo. Esse mundo, portanto, exerce uma força centrípeta sobre nossa subjetividade. Sendo assim, nosso engajamento e nossas ações são motivados pelo estado da realidade, e não pela disposição subjetiva. Então, da mesma forma que tememos a máscara de Tengu por ela ser temível, lutamos contra a injustiça porque há injustiça. Este é o fim da moral do ressentimento e a legitimação das causas sociais. Sendo assim, se houverem disputas entre movimentos sócio-políticos, essa disputa será pela interpretação da realidade e não se baseará em acusações psicologistas ad hominem. É por isso que se pode afirmar que as feministas lutam porque entendem que há machismo na sociedade, e não porque lhes faltam maridos, como outrora tentou-se fazer crer. As pessoas que lutam, lutam porque existem campos

\footnotetext{
${ }^{89}$ Neste ponto, também enxergo reverberações e terreno fértil para os estudos contemporâneos da psique humana: “(...) sentimentos não são estados internos, que nós experimentamos apenas individualmente ou que precisamos decodificar primeiramente nos outros, mas eles são primeiramente vivências comuns, que nós compartilhamos com outros em uma ressonância intercorporal”. (FUCHS, 2018, p. 43).
} 
de batalha, a natureza de tais campos pode ser questionada, mas não deslegitimada por argumentos sobre as motivações dos lutadores.

O que dizer, então, sobre a crítica à causalidade psicológica e ao mecanicismo psíquico? Aqui, a fenomenologia de Sartre está deslegitimando toda forma de reificação humana, seja numa teoria psicológica equivocada, como também numa física social autoritária ou num chão de fábrica. Humanos são criadores de sentido para o mundo, não engrenagens previsíveis e, logo, criaturas afeitas ao controle. Portanto, é possível ver que a ética da fenomenologia de Sartre não se reduziu ao papel de motivação inicial do jovem filósofo, mas constitui a carne latente de toda a obra resultante da leitura de Husserl.

É verdade que o tema "ética em Sartre” faz franzir a testa de qualquer comentador. Trata-se, certamente, de um terreno conceitual perigoso para elaborarmos afirmações. Mas se é perigoso ou complicado, certamente não significa que seja duvidoso ou impossível. Não porque a própria vida do autor - ativa e interessada - tenha se tornado quase que o paradigma do "intelectual engajado", mas sim porque o tom de seus escritos denuncia a todo momento a sua ambição ética. O estudo fenomenológico da consciência constituiu duas bases fundamentais para toda a filosofia sartreana, a saber: as justificativas ontológicas do engajamento e da liberdade. A partir desses conceitos, nasceram a ontologia fenomenológica e o existencialismo. Essa última filosofia, como sabemos, traz uma dificuldade que parece incontornável: O que fazer de nossas existências, uma vez que não há um porquê de nossas existências ${ }^{90}$ ? A partir desse questionamento, se entendermos por ética o desenvolvimento de um tratado moral, cheio de preceitos precisos e fundados em verdades absolutas, de fato, nunca veremos a possibilidade para a ética em Sartre. Mas se a considerarmos como o modo honesto de interação do ser auto ciente com sua própria existência - existência essa que pode ser definida como consciência da própria existência enquanto relação consigo, com outros e com o mundo

\footnotetext{
90 Também aqui, vejo questões interessantes colocadas para a psicoterapia. "O fato de a vida não ser simplesmente dada de maneira prévia ao homem, mas lhe ser entregue como tarefa, significa ao mesmo tempo um perigo mais elevado, a saber, um perigo existencial. Por meio de suas próprias decisões, ele pode deixar de alcançar suas metas ou valores, correndo um risco elevado demais; só o homem pode fracassar na vida." (FUCHS, 2018, p. 13). Para esse psiquiatra contemporâneo, esse tipo de abertura que caracteriza a consciência humana é condição da vulnerabilidade existencial; porta de abertura para toda sorte de perturbações psíquicas e adoecimento mental. Esses apontamentos - que podem constituir uma futura pesquisa - apenas querem chamar atenção para a relevância da fenomenologia e do existencialismo para o estudo contemporâneo da psique humana.
} 
- então veremos na filosofia sartreana um terreno pleno de propostas para a ação e para a vida; a tábua de valores para essa ética é a autenticidade existencial. 


\section{Bibliografia:}

\section{Bibliografia primária:}

1. (E.) SARTRE, J. P. Esquisse d'une théorie des émotions. Paris: Herman, 1975.

2. (I.) . "Une idée fondamentale de la phénoménologie de Husserl: L'intentionnalité”. In Coorebyter, V. (ed). La transcendance de l'Ego et autres textes phénoménologiques. Paris: Vrin, 2003a.

3. (T.E.)__L_L_ .La transcendence de l'Ego: Esquisse d'une description phénoménologique”. In Coorebyter, V. (ed). La transcendance de l'Ego et autres textes phénoménologiques. Paris: Vrin, 2003b.

4. . L'imagination. Paris: PUF, 2010.

\section{Bibliografia secundária:}

5. BARATA, A. "Towards a theory of action in Sartre's philosophy. From action to ethics”. Paris: Philonsorbonne, v. 12, 2018.

6. BÉGOUT, B. La généalogie de la logique, Cap. III. Paris: Vrin, 2000.

7. CABESTAN, P. Qui suis je? Sartre et la question du sujet. Paris: Hermann, 2015.

8. Daneinsanálise: Fenomenologia e psiquiatria. Rio de Janeiro: Viva Verita, 2015.

9. CASTRO, P. A. Metafísica da imaginação: Estudos sobre a consciência irrealizante a partir de Sartre. Lisboa: Quimera Editores, 2006.

10. COOREBYTER, V. de. "Introduction". In Coorebyter, V. (ed). La transcendance de l'Ego et autres textes phénoménologiques. Paris: Vrin, 2003.

11. . "Os paradoxos da consciência". In Castro F. et al.

(org.). J-P. Sartre e os desafios à psicologia contemporânea. Rio de Janeiro: Via Vérita, 2017.

12. . Sartre face à la phénoménologie: Autour de "L'intentionnalité" et de "La transcendence de l'Ego”. Bruxelles: Ousia, 2000.

13. . "De Husserl à Sartre. La structure intentionnelle de l'image dans L'Imagination et L'Imaginaire”, Methodos [En ligne], 12 | 2012.

14. DESCARTES. R. Meditações metafísicas. São Paulo: Nova Cultural, Coleção os pensadores, 1991. 
15. FUCHS, T. Para uma psiquiatria fenomenológica: Ensaios e conferências sobre as bases antropológicas da doença psíquica, memória corporal e si mesmo ecológico. Rio de Janeiro: Via Vérita, 2018.

16. HUSSERL, E. A ideia da fenomenologia. Lisboa: Edições 70, 1986.

17. - Ideias para uma fenomenologia pura e para uma filosofia fenomenológica. Aparecida: Ideias \& Letras, 2006.

18. . Recherches logiques. Paris: PUF, 1969

19. . Analyses concerning passive and active synthesis. Illinois: Kluwer, 2001.

20. JOANNIS, D. G., Sartre et le problème de la connaissance. Sant-Nicolas (Québec): Université Laval, 1996.

21. KANT, I. Crítica da Razão Pura. São Paulo: Nova Cultural, Coleção os pensadores, 1999.

22. MOUILLE, J.M. Sartre : conscience, ego et psychè. Paris: PUF, 2000.

23. MOURA, C. E. de. Consciência e liberdade em Sartre: por uma perspectiva ética. São Carlos: Edufscar, 2012.

24. MOUTINHO, L. D. S. Sartre: existencialismo e liberdade. São Paulo: Moderna, 1995a.

25. Sartre: psicologia e fenomenologia. São Paulo: Brasiliense, 1995b.

26. SACRINI, M. A. F. Sartre entre reflexão fenomenológica e reflexão pura. Goiânia: Philósophos, v.17, n.1, 2012.

27. SARTRE, J. P. "Conscience do soi et connaissance de soi». In Coorebyter, V. (ed). La transcendance de l'Ego et autres textes phénoménologiques. Paris: Vrin, $2003 c$.

28. . Diário de uma guerra estranha. Rio de Janeiro: Nova Fronteira, 1995.

29. . L'être et le néant: essai d'ontologie phénoménologique. Paris: Tel Gallimard, 2011.

30. . L'existentialime est un humanisme. Paris: Folio, 2002.

31. . A Náusea. s. 1: Publicações Europa-América, 1976.

32. . Situations philosophiques I. Paris: Gallimard, 1990.

33. SILVA, F. L. e. Sartre e o humanismo. São Paulo: Barcarolla, 2014. 34. . Ética e literatura em Sartre. São Paulo: UNESP, 2004. 